This item was submitted to Loughborough's Research Repository by the author.

Items in Figshare are protected by copyright, with all rights reserved, unless otherwise indicated.

\title{
Impact of water matrix on the removal of micropollutants by advanced oxidation technologies
}

PLEASE CITE THE PUBLISHED VERSION

https://doi.org/10.1016/j.cej.2019.01.080

\section{PUBLISHER}

(C) Elsevier

\section{VERSION}

AM (Accepted Manuscript)

\section{PUBLISHER STATEMENT}

This paper was accepted for publication in the journal Chemical Engineering Journal and the definitive published version is available at https://doi.org/10.1016/j.cej.2019.01.080.

\section{LICENCE}

CC BY-NC-ND 4.0

\section{REPOSITORY RECORD}

Ribeiro, Ana R. Lado, Nuno F.F. Moreira, Gianluca Li-Puma, and Adrian M.T. Silva. 2019. "Impact of Water Matrix on the Removal of Micropollutants by Advanced Oxidation Technologies". figshare. https://hdl.handle.net/2134/37018. 
Impact of water matrix on the removal of micropollutants by advanced oxidation technologies

Ana R. Ribeiro, ${ }^{1, *}$, Nuno F.F. Moreira ${ }^{1}$, Gianluca Li Puma ${ }^{2, *}$, Adrián M.T. Silva ${ }^{1}$

${ }^{1}$ Laboratory of Separation and Reaction Engineering - Laboratory of Catalysis and Materials (LSRE-LCM), Faculdade de Engenharia, Universidade do Porto, Rua Dr. Roberto Frias s/n, 4200465 Porto, Portugal

${ }^{2}$ Environmental Nanocatalysis \& Photoreaction Engineering, Department of Chemical Engineering, Loughborough University, Loughborough, United Kingdom

*Corresponding authors: ritalado@fe.up.pt (A.R. Ribeiro), G.Lipuma@lboro.ac.uk (G. Li Puma)

\begin{abstract}
Micropollutants (MPs) in the aquatic compartments originate from many sources and particularly from the effluents of urban wastewater treatment plants (UWWTPs). Advanced oxidation technologies (AOTs) usually applied after biological processes, have recently emerged as effective tertiary treatments for the removal of MPs, but the oxidation rates of the single compounds may be largely affected by the constituent species of the water matrix. These species include dissolved organic matter and inorganic species (e.g., carbonate, bicarbonate, nitrite, sulphate, chloride). This review analyses the impact of such substances on common AOTs including photolysis, $\mathrm{UV} / \mathrm{H}_{2} \mathrm{O}_{2}$, Fenton, photocatalysis, and ozone-based processes. The degradation efficiency of single MPs by AOTs results from the combined impact of the water matrix constituents, which can have neutral, inhibiting or promoting effect, depending on the process and the mechanism by which these water components react. Organic species can be either inhibitors (by light attenuation; scavenging effects; or adsorption to catalyst) or promoters (by originating reactive oxygen species (ROS) which enhance indirect photolysis; or by regenerating the catalyst). Inorganic species can also be either inhibitors (by scavenging effects; formation of radicals less active than hydroxyl radicals; iron complexation; adsorption to catalyst or decrease
\end{abstract}


of its effective surface area) or promoters (e.g., nitrate ions by formation of ROS; iron ions as additional source of catalyst). The available data reviewed here is limited and the role and mechanisms of individual water components are still not completely understood. Further studies are needed to elucidate the wide spectrum of reactions occurring in complex wastewaters and to increase the adoption of AOTs in UWWTPs.

Keywords: Advanced oxidation processes; Chemical oxidation technologies; Contaminants of emerging concern; Matrix effect; Micropollutants; Wastewater constituent. 


\section{Contents}

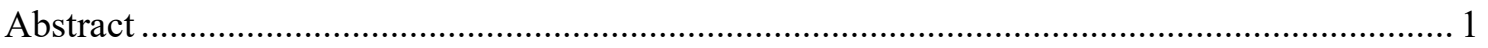

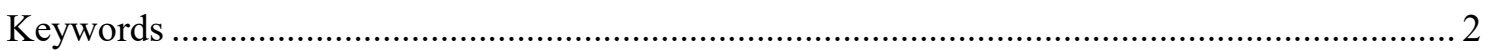

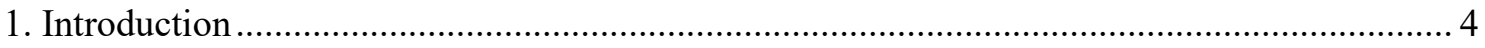

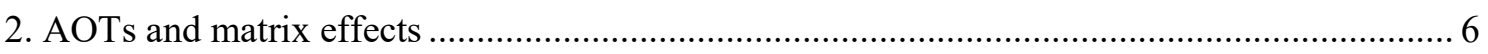

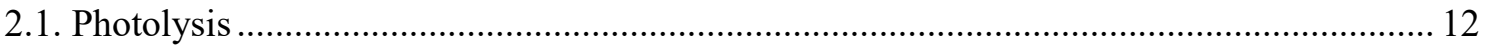

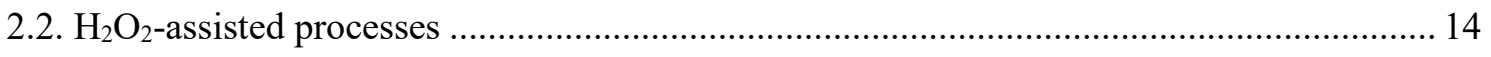

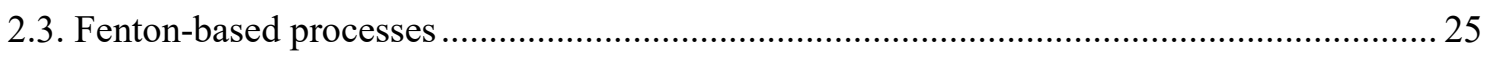

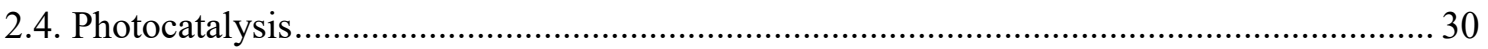

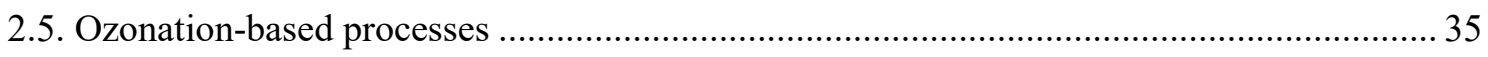

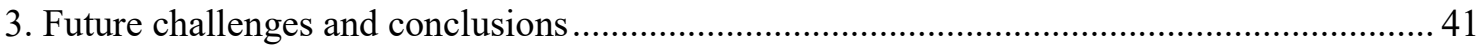

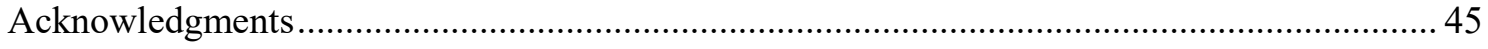

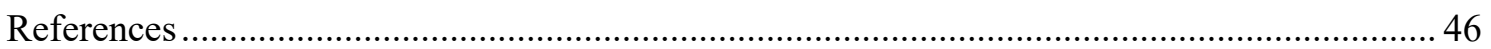


1

2 Micropollutants (MPs) are natural or anthropogenic substances occurring in the aquatic

3 environment at low concentrations, usually between $n g \mathrm{~L}^{-1}$ and $\mu \mathrm{g} \mathrm{L}^{-1}$ levels. MPs comprise a

4 vast array of substances, namely pesticides, industrial compounds, pharmaceuticals, personal care

5 products, steroid hormones, drugs of abuse and others [1]. Many of them are considered

6

7

8 contaminants of emerging concern (CECs), a term currently used in the framework of environmental sciences for: (i) compounds recently known (e.g., new synthetic substances); (ii) hazardous compounds recently identified as such despite the previous knowledge about their occurrence in the environment (e.g., estrogens); and (iii) previously unknown compounds present in the environment, which have only been detected due to advances in analytical methods and instrumentation [2].

The anthropogenic sources of MPs are numerous and include domestic, hospital and industrial wastewater, agriculture runoff, livestock and aquaculture [2]. The treated effluents released by urban wastewater treatment plants (UWWTPs) are consensually recognised as a significant origin of MPs, since UWWTPs using conventional physicochemical and biological treatments are not designed to fully eliminate organic compounds occurring at trace concentrations [1-3]. MPs in domestic and hospital wastewater reach UWWTPs after metabolism and excretion as parent compounds and/or metabolites, although the release by direct discharge of unused or expired drugs may also be a significant contributing factor [3]. MPs in industrial effluents discharged into UWWTPs are generally poorly removed, even when these have been previously treated at industrial level [3]. Therefore, the uninterrupted discharge of MPs and their metabolites into UWWTPs can be considered a continuous source of toxicity which harms the receiving aqueous compartments, such as surface, ground and drinking waters.

Innovative advanced oxidation technologies (AOTs), including chemical oxidation technologies (COTs) and advanced oxidation processes (AOPs), have recently gaining interest as polishing post-treatment methods usually applied after biological processes in water and wastewater treatment. Such processes are designed to enhance the degradation and mineralization of MPs or 
to transform them into less toxic compounds [1]. In highly toxic water effluents, AOTs can be applied as a pre-treatment, to enhance the biodegradability of the water and reduce its toxicity. The installation of supplementary AOTs after secondary biological treatment has been triggering a huge interest among the water industry, due to the recognized efficiency of such processes for the removal of a wide range of MPs from UWWTPs effluents [1]. The reduction of the release of MPs into the aquatic compartments, therefore, improves the effluent quality and can promote the reuse of reclaimed water.

AOTs are widely studied technologies for the oxidation of organic MPs via reactions with the highly reactive radicals. Hydroxyl radical-mediated AOTs utilize hydroxyl radicals (HO'), the most powerful oxidizing species after fluorine, with an $\mathrm{E}^{0}=2.80 \mathrm{~V}$ [4]. These unselective radicals might mineralize the parent compounds with no generation of secondary waste, yielding $\mathrm{CO}_{2}$, $\mathrm{H}_{2} \mathrm{O}$ and inorganic ions as final products [1]. AOTs can be classified as chemical, photochemical, electrochemical, sonochemical and hydrochemical processes, depending on the way the $\mathrm{HO}^{\bullet}$ are generated, or as homogeneous and heterogeneous processes, depending on the number of phases involved during the transport and reaction of the species. Homogeneous processes include processes that utilize $\mathrm{UV}, \mathrm{H}_{2} \mathrm{O}_{2}$, the Fenton reagent, dissolved $\mathrm{O}_{3}$, wet oxidation (WO) and wet peroxide oxidation (WPO); whereas heterogeneous AOTs comprise heterogeneous photocatalysis, heterogeneous Fenton-like processes, catalytic and photocatalytic ozonation, catalytic wet oxidation (CWO) and catalytic wet peroxide oxidation (CWPO). UV, $\mathrm{UV} / \mathrm{H}_{2} \mathrm{O}_{2}$ and ozonation processes have been successfully implemented in full-scale UWWTPs to degrade MPs. AOTs not yet applied at full-scale include $\mathrm{UV} / \mathrm{O}_{3}, \mathrm{UV} / \mathrm{O}_{3} / \mathrm{H}_{2} \mathrm{O}_{2}, \mathrm{UV} / \mathrm{H}_{2} \mathrm{O}_{2} / \mathrm{Fe}$ (mild photoFenton) and other advanced processes such as heterogeneous photocatalysis, heterogeneous photo-Fenton, photocatalytic ozonation, photocatalytic membrane processes, electrochemical oxidation and sonolysis [1]. This review focuses on the treatment of MPs by hydroxyl radicalmediated AOTs and related processes and on the impact of the water matrix components, which is particularly deficient on sulphate and chlorine radical-mediated AOTs. Sulphate radicalmediated AOTs have recently gained a great attention due to the high redox potential of $\mathrm{SO}_{4}{ }^{-}$, 
which is comparable with that of $\mathrm{HO}^{*}$ [5]. While $\mathrm{HO}^{*}$ is reported to react with MPs through three competing pathways (addition, hydrogen abstraction, and electron abstraction), $\mathrm{SO}_{4}{ }^{--}$reacts preferentially through an electron transfer mechanism. Both radicals can react with inorganic ions (e.g., $\mathrm{Cl}^{-}$and $\mathrm{CO}_{3}{ }^{2-}$ ), generating secondary reactive species $\left(\mathrm{Cl}^{\circ} / \mathrm{CO}_{3}{ }^{-}\right)$with relatively high reactivity with MPs [5]. Conversely, chlorine radical-mediated AOTs (e.g., UV/chlorine) are based on selective oxidants produced by photolysis of chlorine: $\mathrm{Cl}^{-}$(selective and with higher reactivity than $\mathrm{HO}^{*}$ for certain organic compounds, such as benzoic acid, chlorobenzene, and phenol), $\mathrm{Cl}_{2}{ }^{*}$ (selective for olefinic compounds and aromatics ring-substituted with hydroxy, methoxy and amino groups) and $\mathrm{ClO}^{\circ}$ (selective for aromatics possessing methoxy groups), with redox potentials of 2.4, 2.0, and 1.5-1.8 V, respectively [6]. The use of AOTs in hybrid processes has been also envisaged through integration with membrane technologies and through the coupling of two or more AOTs. This last strategy can result: (i) typically in a synergistic effect due to the positive interactions among the single processes; (ii) in a cumulative effect caused by the increased generation of reactive oxygen species (ROS); and less commonly (iii) in an antagonistic effect, due to excessive formation of ROS, which may act as self-scavengers [7].

\section{AOTs and matrix effects}

Overall, the elimination of MPs by AOTs is largely influenced by the quality of the water matrix that needs to be treated, and the effectiveness results from the impact of the dissolved components, which can have neutral, inhibitory or promoting effects. The composition of the water matrix can also have a significant impact on the inactivation of bacteria in water disinfection processes, as shown in the literature $[8,9]$.

The occurrence of scavengers in the matrix may also hinder the removal of dissolved organic matter (DOM), representing the main fraction of the effluent organic matter (a heterogeneous mixture of recalcitrant organic compounds comprising natural organic matter (NOM), soluble microbial products and trace MPs) present in biologically treated urban wastewater [10]. The composition of DOM depends on the wastewater sources (domestic, industrial, agricultural, etc.), 
82 location, the season of the year and the operating conditions (temperature, $\mathrm{pH}$, flow, etc.) [11].

83 The structural and functional complexity of DOM turns difficult its full characterization,

84 therefore, the DOC is commonly used as a surrogate parameter for its quantification, providing a

85 general assessment and lacking on structural elucidation [10]. Its transformation and the

86 generation of by-products during WWTP processes may change the biological properties and

87 environmental impact of the DOM, but the knowledge about its transformation in the WWTPs is

88 still limited. A recent review on this subject described the characterization of DOM based on its

89 MW distribution, hydrophobicity and optical properties [11]. Several analytical techniques have

90 been used to characterize the chemistry and reactivity of the DOM components, including

91 physicochemical analysis, spectroscopic, chromatographic, and thermal degradation methods,

92 and other fractionation techniques [10]. Wastewater components include a broad range of organic

93 (e.g., NOM composed by humic and fulvic acids, carbohydrates, proteins) and inorganic species

94 (e.g., carbonate, bicarbonate, nitrite, sulphate, chloride), which react with $\mathrm{HO}^{*}$, either competing

95 with organic MPs for oxidation $[1,10]$ or forming the respective radicals with lower oxidation

96 potential [12]. Moreover, some wastewater components are able to favour the efficiency of certain

97 AOTs. Figure 1 summarizes the key factors that contribute to the removal efficiency of MPs by the AOTs discussed in this review, acting as either promoters or as inhibitors. 


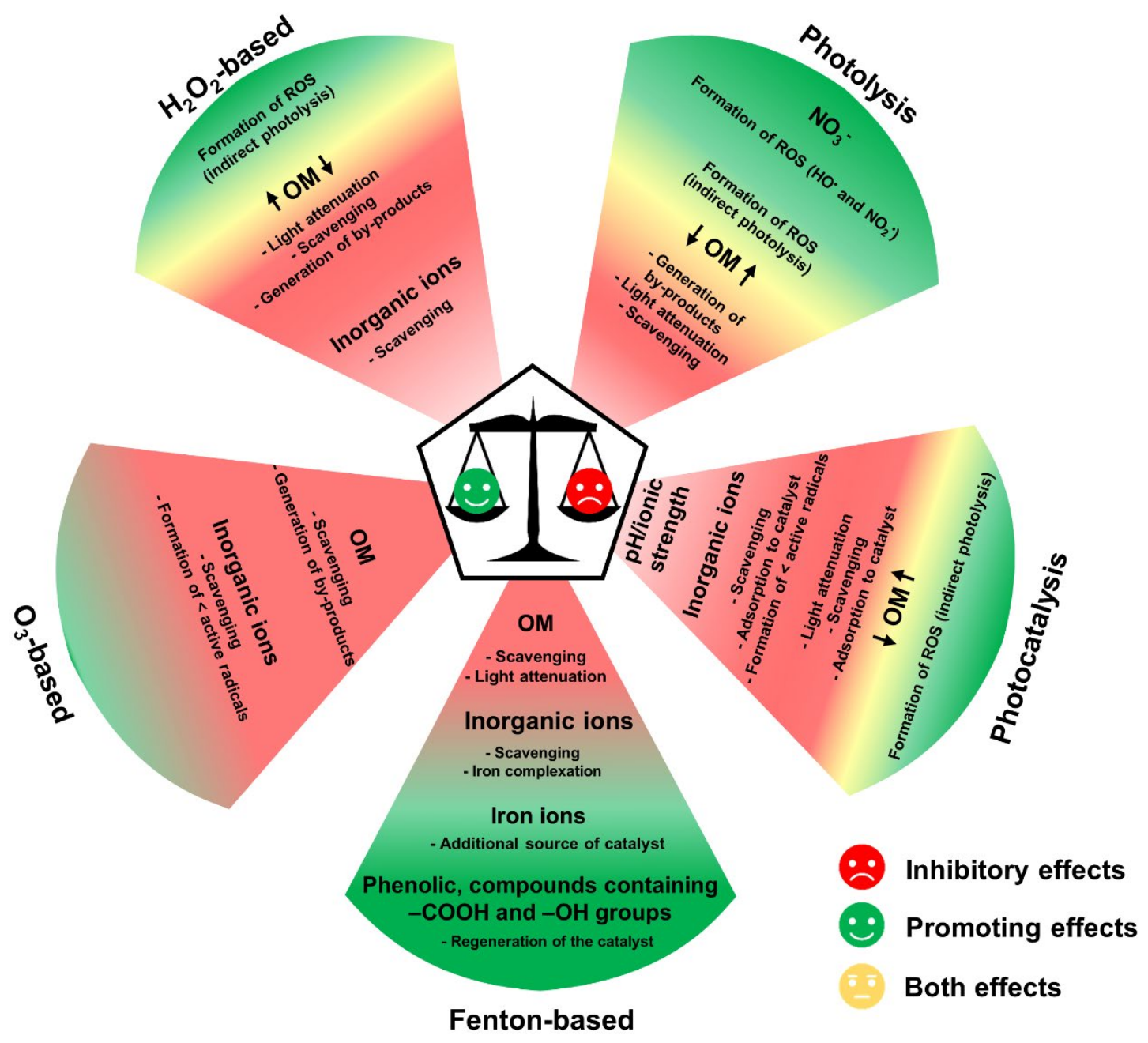

Figure 1. Schematic representation of the reported inhibitory and promoting effects of wastewater components, affecting the efficiency of photolysis, $\mathrm{H}_{2} \mathrm{O}_{2}$-based, Fenton-based, photocatalysis, and ozonebased processes.

The main scavengers of $\mathrm{HO}^{*}$ in natural waters include $\mathrm{NOM}$, bromide (which forms $\mathrm{BrOH}^{--}$by reacting with $\mathrm{HO}^{*}$ ) [5], and carbonate/bicarbonate species [13]. Hence, different water matrices containing NOM exhibit different scavenging rates, reducing the fraction of ROS available to degrade MPs, which triggers the need of considering such scavengers in the optimization of AOTs. In most cases, the MPs removal kinetics decrease with an increase in the complexity of the water matrix, since this may contain numerous non-target organic and inorganic species that compete with the target contaminants for oxidants [14]. The inhibitory effects of co-existing 
112 substances in the matrix include also light absorption and attenuation in processes utilizing UV

113 radiation. It may also result in the formation of less active complexes with iron species in Fenton-

114 based processes and in the competition for catalytic active sites, catalyst deactivation by poisoning

115 of the active sites or fouling of the surface area of the catalysts in heterogeneous catalytic

116 processes, as well as the modification of the electrical surface charge due to the $\mathrm{pH}$ or ionic

117 strength. However, it has been reported that non-target species may also act as promoters in

118 selected AOTs [4, 14]. Photosensitizers organic and inorganic species in the water matrix can

119 promote the production of ROS by UV irradiation, leading to indirect photolysis [15]. For

120 instance, $\mathrm{NO}_{3}{ }^{-}$is able to produce $\mathrm{HO}^{\circ}$ and $\mathrm{NO}_{2}{ }^{\circ}$ radical species, promoting the photodegradation

121 of MPs, especially those in which indirect photolysis is the main reactive pathway (e.g., caffeine,

122 carbamazepine, diuron, simazine, 2,4-dichlorophenoxyacetic acid) [15]. Fenton-based processes

123 are generally promoted by natural occurring iron in the wastewater which acts as an additional

124 catalytic source, by the presence of phenolic compounds that may reduce the ferric ions to ferrous

125 ions regenerating the catalyst, and by dissolved compounds containing $-\mathrm{COOH}$ and $-\mathrm{OH}$ groups

126 which complexes ferric ions in solution, where the complexes may have higher quantum yields

$127 \quad[16]$.

128 Despite the great attention given to AOTs (Figure 2, left), only ca. 10\% of the published papers

129 refer to the treatment of actual wastewater and a few of them (ca. $0.2 \%$ ) have addressed the impact

130 of the water matrix (Figure 2, right).

131 


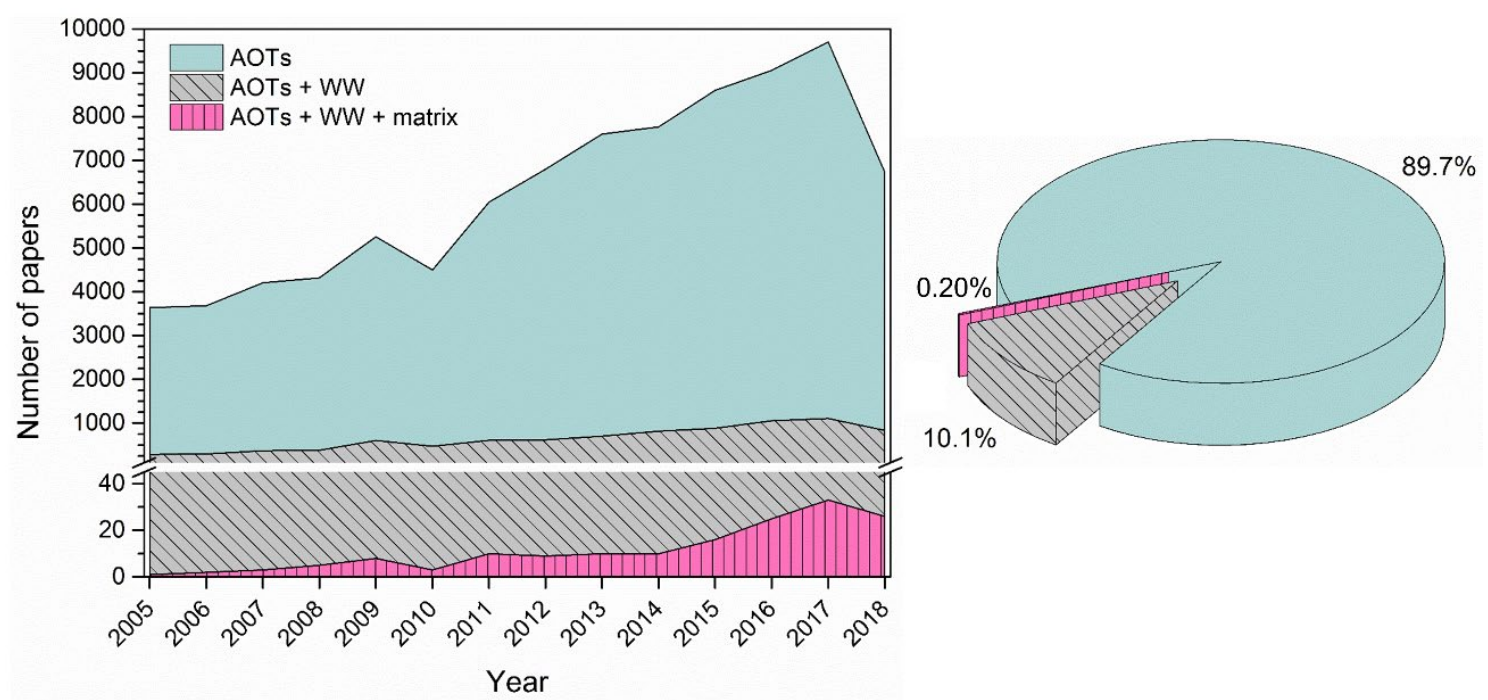

Figure 2. Number of papers published by year in the period 2005-2018 (left) and their relative frequency in the whole period (right), displayed by searching publications dealing with the different types of AOTs discussed in this review, using as keywords (abstract, title, keywords): "photolysis" or " $\mathrm{UV} / \mathrm{H}_{2} \mathrm{O}_{2}$ " or "Fenton" or "photocatalysis" or "ozonation" or "ozonolysis" or "UV/O ${ }_{3}$ " or "peroxone" $(\square)$; and "wastewater" (₫); and "matrix effect" or "matrix component" or "matrix constituent" or "water

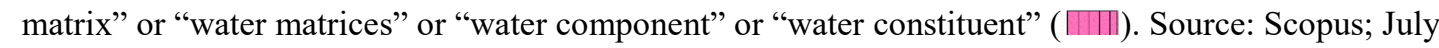
2018.

Interestingly, although the amount of publications in this field has been markedly increasing, the number of papers dealing with wastewater treatment and the impact of the water matrix follows the same trend, with almost no variations on their relative frequency. In fact, most studies on AOTs for water/wastewater treatment have been performed using aqueous solutions spiked with model contaminants. Often, ultrapure or distilled water is spiked with the contaminant at concentration levels higher than those actually reported in environmental compartments [14]. This methodology allows: (i) to exclude the interactions between the contaminant, the oxidizing species and the matrix components; (ii) to study degradation pathways of specific compounds; (iii) to evaluate the performance of the studied treatment for target contaminants; and (iv) to use simple and widely used analytical techniques. However, the quality of the aqueous matrix for which the treatment is proposed is crucial to draw accurate conclusions about the effectiveness of 
the AOT, its suitability and practicability for the treatment of real contaminated waters. Therefore,

153 this review focuses on the available data of matrix effects on the removal of MPs from effluents

154 of UWWTPs by using photolysis, UV/ $\mathrm{H}_{2} \mathrm{O}_{2}$, Fenton, photocatalysis, or ozone-based processes,

155 and give insights about the options that improve the effectiveness of AOTs already implemented

156 or under investigation. The search comprised publications since 2005 in Scopus database, using the following keywords (abstract, title, keywords): "photolysis" or " $\mathrm{UV} / \mathrm{H}_{2} \mathrm{O}_{2}$ " or "Fenton" or "photocatalysis" or "ozonation" or "ozonolysis" or "UV/OO " or "peroxone" and "wastewater" and "matrix effect" or "matrix component" or "matrix constituent" or "water matrix" or "water matrices" or "water component" or "water constituent" (Figure 2). From this survey, only studies dealing with real wastewater were considered, namely by comparing it with ultrapure water or other matrices, testing wastewater from different origins, or by assessing the effect of adding supplementary water components.

In the last decade, many studies using actual matrices have been reported in the literature, most showing an application for a real matrix, after screening studies on synthetic aqueous solutions, and/or dealing with spiked MPs at concentration levels higher than those found in the environment. More recently, some reports have shown the influence of the quality and/or quantity of water components, on the process efficiency. Most of these works are focused on the comparison of removal efficiencies of MPs and/or dissolved organic carbon (DOC) in distilled/ultrapure water versus synthetic wastewaters [17, 18] and/or actual wastewaters [4]. Some studies comparing wastewaters from different origins [19] or at different treatment stages in the UWWTP [20], have been recently reported. Several authors have also shown the effects of wastewater components (e.g., humic acids (HA), fluvic acids, surfactants, inorganic species) on the removal of selected MPs frequently found in urban wastewater; however, these studies often address the impact on ultrapure or distilled water, rather than in real wastewater. A current approach has been performed by adding different components (organic and/or inorganic) to

177 natural water, giving more accurate insights on the effects of wastewater components on the removal efficiencies of either MPs or DOC. Studies using environmental matrices at real 
concentrations and providing a deep understanding on the effects of the organics and inorganics occurring in the matrices, are still limited.

\subsection{Photolysis}

UV water treatment can involve two mechanisms, direct or indirect photolysis. The direct photolysis of organic substances by UV radiation (typically at $\lambda=254 \mathrm{~nm}$ ) promotes the electronic excitation of the molecules, leading to: (i) electron transfer from an excited state of the organic compounds to molecular oxygen; or (ii) homolysis of the organic substance, producing organic radicals that further react with oxygen [20-22].

The water matrix can play an essential role on the yield of photodegradation reactions, depending on the presence of promoting and inhibitory substances. Table 1 summarizes the reports published since 2005 referring to the evaluation of matrix effects on photolysis (more details can be found in Table S1). Generally, lower contaminants removal rates are expected in wastewater effluents in comparison to a ultrapure water matrix, which can be enlightened by the presence of NOM absorbing a fraction of the incident radiation [23]. The main factors regulating the inhibitory effect of NOM are: (i) light attenuation caused by suspended particles; (ii) scavenging effects of NOM; and (iii) generation of NOM by-products [24]. Nevertheless, the wastewater components might enhance the removal rate of certain MPs by mean of indirect photolysis, resulting from the action of ROS originated by the irradiation of photosensitizers dissolved in the water matrix [4]. Photosensitizers comprise a wide variety of organic compounds found in DOM that can undergo diverse photochemical reactions, producing ROS that initiate MPs degradation. Such ROS may in certain cases offset the reduction of transmittance of NOM containing matrices, which in turn diminishes the degradation by direct photolysis (e.g., studies in wastewater and in drinking water) [25]. DOM photosensitizers act by absorption of light (Reaction 1) followed by excitation to a single state $\left({ }^{1} \mathrm{DOM}^{*}\right)$, which has typical short lifespans (ps to ns) and consequent little interaction with organic MPs. This is partially transformed to their excited triplet state $\left({ }^{3} \mathrm{DOM}^{*}\right)$, which has a longer lifespan (order of $\mu \mathrm{s}$ ) $[21,26]$. The ${ }^{3} \mathrm{DOM}^{*}$ species are believed to be the main reactive 
species in the reactive pathways and the deactivation of the excited triplet state can occur by reaction with other organic molecules (e.g., target MPs), which are consequently oxidized [24]. These species can play an important role in indirect photolysis for phenols and aromatic amines [27]. Another deactivation mechanisms of ${ }^{3} \mathrm{DOM}^{*}$ include the transition to their ground state or the transfer of energy to $\mathrm{O}_{2}$ (Reaction 2), producing singlet molecular oxygen $\left({ }^{1} \mathrm{O}_{2}\right.$ ), which also act as a photo-oxidant [21].

${ }^{3} \mathrm{DOM}^{*}+\mathrm{O}_{2} \rightarrow \mathrm{DOM}+{ }^{1} \mathrm{O}_{2}$

214 For instance, the photodegradation of cocaine in a synthetic municipal wastewater effluent by direct sun-light exposure was higher ( $90 \%$ after $20 \mathrm{~h}$ of irradiation) than that observed in distilled water ( $22 \%$ after $60 \mathrm{~h}$ of irradiation), without mineralization taking place in both investigated matrices [17]. This phenomenon has also been reported for the degradation of diclofenac under UVA radiation, with a higher removal rate registered in wastewater than in ultrapure water, due to some naturally occurring substances in the effluent, acting as photosensitizers [28].

The anion $\mathrm{NO}_{3}{ }^{-}$may also play an important role in the UV treatment. This inorganic species can generate $\mathrm{HO}^{\bullet}$ and $\mathrm{NO}_{2}{ }^{\circ}$ (Reactions 3-7) under direct UV photolysis (mainly at wavelength below $240 \mathrm{~nm}$ ), consequently increasing the degradation of some compounds [24].

$\mathrm{NO}_{3}^{-}+h v \rightarrow \mathrm{O}^{--}+\mathrm{NO}_{2}{ }^{-}$

$\mathrm{O}^{--}+\mathrm{H}_{2} \mathrm{O} \rightarrow \mathrm{HO}^{\bullet}+\mathrm{HO}^{-}$

This promoting effect has been observed during the degradation of several phenolic compounds [29], cytostatic drugs [24], pharmaceuticals [30] and pesticides [15]. A study on the photodegradation of antibiotics suggested that the promoting effect of $\mathrm{NO}_{3}{ }^{-}$on the photolysis of 
231 salinomycin resulted from the reaction with produced reactive nitrogen species, besides the

232 indirect photolysis [30]. Another study reported an appreciable promoting effect of $\mathrm{NO}_{3}{ }^{-}$on those

233 compounds which followed an indirect degradation photolytic pathway, while the impact was

234 minor on those compounds more susceptible to direct photolysis [15]. This fact can be explained

235 by the reduction of the photonic energy in the aqueous solution, when the target compounds strongly absorb in the same UV range as $\mathrm{NO}_{3}{ }^{-}[31]$.

\section{2. $\mathrm{H}_{2} \mathrm{O}_{2}$-assisted processes}

$\mathrm{UV} / \mathrm{H}_{2} \mathrm{O}_{2}$ is an AOT that combines the instantaneous UV photolytic effect (either direct or indirect) and the reaction with $\mathrm{HO}^{*}$ originated from the homolytic disruption of $\mathrm{H}_{2} \mathrm{O}_{2}$ (initiation, propagation and termination, Reactions $8-12$, Table S2 summarizes the reaction rate constants)

242 [20]. UV/ $\mathrm{H}_{2} \mathrm{O}_{2}$ is an alternative solution for the elimination of organic MPs with low reactivity the treatment of wastewaters with high concentration of bromide since this process avoids bromate formation [13].

$\mathrm{H}_{2} \mathrm{O}_{2}+h v \rightarrow 2 \mathrm{HO}^{*}$

$\mathrm{H}_{2} \mathrm{O}_{2}+\mathrm{HO}^{\cdot} \rightarrow \mathrm{HO}_{2}{ }^{\cdot}+\mathrm{H}_{2} \mathrm{O}$

$2 \mathrm{HO}_{2}{ }^{\cdot} \rightarrow \mathrm{H}_{2} \mathrm{O}_{2}+\mathrm{O}_{2}$

$\mathrm{HO}^{\bullet}+\mathrm{HO}_{2} \cdot \rightarrow \mathrm{O}_{2}+\mathrm{H}_{2} \mathrm{O}$

251 Although $\mathrm{H}_{2} \mathrm{O}_{2}$ produces $\mathrm{HO}^{*}$ under $\mathrm{UV}$ irradiation, at elevated concentrations it also scavenges

$252 \mathrm{HO}^{\bullet}$ (Reactions 9-12), hindering the oxidation of the target organic MPs, therefore the dose of $253 \mathrm{H}_{2} \mathrm{O}_{2}$ needs to be controlled very carefully in order to maximize the removal rate of MPs [25].

254 Furthermore, $\mathrm{H}_{2} \mathrm{O}_{2}$ is a major contributor to the operating cost of the $\mathrm{UV} / \mathrm{H}_{2} \mathrm{O}_{2}$ process [25]. 
In the $\mathrm{H}_{2} \mathrm{O}_{2}$-assisted photocatalysis, it is likely that $\mathrm{H}_{2} \mathrm{O}_{2}$ promotes the degradation of target water contaminants by reacting with conduction band electrons (Reaction 13) and the superoxide radical $\left(\mathrm{O}_{2}{ }^{--}\right)$(Reaction 14) to produce $\mathrm{HO}^{\bullet}$ and anions [32]. The formation of additional oxidizing species and the suppression of the recombination of $\mathrm{e}^{-} / \mathrm{h}^{+}$pairs, in the case of photocatalysis, enhance the effectiveness of this AOT [32].

$$
\mathrm{H}_{2} \mathrm{O}_{2}+\mathrm{e}^{-} \rightarrow \mathrm{HO}^{-}+\mathrm{HO}^{\cdot}
$$

$$
\mathrm{H}_{2} \mathrm{O}_{2}+\mathrm{O}_{2}{ }^{--} \rightarrow \mathrm{HO}^{-}+\mathrm{HO}^{\bullet}+\mathrm{O}_{2}
$$

Similarly to the $\mathrm{UV} / \mathrm{H}_{2} \mathrm{O}_{2}$ process, an optimum $\mathrm{H}_{2} \mathrm{O}_{2}$ concentration can also be determined in the $\mathrm{H}_{2} \mathrm{O}_{2}$-assisted photocatalysis process, depending on the reaction and system conditions, above which $\mathrm{H}_{2} \mathrm{O}_{2}$ acts as electron and radical scavenger, ultimately reducing the degradation rate of MPs [32].

Water quality parameters, such as the specific UV absorbance and the presence of $\mathrm{HO}^{\circ}$ scavengers (e.g., NOM and high alkalinity), can adversely affect the degradation of MPs [33]. Diverse water matrices may have different scavenging rates since the rate constant for the reaction of DOM with $\mathrm{HO}^{*}$ depends on the nature of the DOM [13]. Table 1 summarizes the studies published since 2005 reporting the evaluation of water matrix effects on the effectiveness of $\mathrm{H}_{2} \mathrm{O}_{2}$-assisted processes (more details can be found in Table $\mathrm{S} 1$ ). In the $\mathrm{UV} / \mathrm{H}_{2} \mathrm{O}_{2}$ process, the matrix components may: (i) absorb UV light which is required to generate $\mathrm{HO}^{\bullet}$ from $\mathrm{H}_{2} \mathrm{O}_{2}$; and (ii) compete with the MPs for the reaction with $\mathrm{HO}^{*}$, therefore, lowering the steady-state concentration of radicals in solution [34]. The NOM competes with MPs by consuming a fraction of the oxidant, and consequently higher oxidant doses are usually required to achieve a specific removal of MPs in the presence of NOM [35]. In addition, the water components may affect the chemical nature of the oxidation by-products formed, which in turn may affect the water quality characteristics [33]. Moreover, the breakdown of DOM into smaller molecules can promote the faster decay rates of MPs due to the formation of HO, peroxyl radicals, and excited singlet, doublet or triplet states of oxygen, which may increase the removal of organics MPs in DOCenriched waters [36]. 
282 Another important factor that may affect the performance of $\mathrm{H}_{2} \mathrm{O}_{2}$-assisted processes is the 283 concentration of inorganic carbon (IC) in the water sample [37]. A high carbonate/bicarbonate 284 content may scavenge $\mathrm{HO}^{\circ}$, according to the following reactions (Reactions 15-16):

$285 \mathrm{HO}^{*}+\mathrm{HCO}_{3}^{-} \rightarrow \mathrm{H}_{2} \mathrm{O}+\mathrm{CO}_{3}{ }^{-}$

$286 \mathrm{HO}^{*}+\mathrm{CO}_{3}^{2-} \rightarrow \mathrm{HO}^{-}+\mathrm{CO}_{3}{ }^{-}$

287 The carbonate radical $\left(\mathrm{CO}_{3}{ }^{\circ}\right)$ can be also formed via the reaction of carbonate/bicarbonate with $288{ }^{3} \mathrm{DOM}^{*}[27]$. Regardless of the origin, this radical is a potent oxidant with a one electron reduction 289 potential of $1.78 \mathrm{~V}(\mathrm{pH} 7)$. It is more selective than $\mathrm{HO}^{\circ}$ as oxidant, mainly reacting with electron 290 rich compounds such as phenols, S- and N-containing compounds [27].

291 Therefore, both effects can occur in wastewater samples with high DOC and IC: (i) 292 carbonate/bicarbonate scavenge or compete for $\mathrm{HO}^{*}$, besides other inorganic scavengers that may 293 interfere with the degradation of MPs [37], such as nitrate, chloride, and sulphate [25, 38]; and 294 (ii) the $\mathrm{CO}_{3}{ }^{-}$formed may react with those selected compounds with high second-order rate 295 constant values [27]. 
Table 1. Matrix effects occurring in studies dealing with the AOTs discussed in this review, published since 2005 (* refers to different sources of wastewater and/or wastewater collected at different stages of treatment). Details of each study can be found in Supplementary Material (Tables S1/S3-S5).

\begin{tabular}{|c|c|c|c|c|c|c|c|c|c|c|c|c|c|c|c|c|}
\hline \multirow{2}{*}{ AOT } & \multirow{2}{*}{ Target pollutant } & \multirow{2}{*}{$\begin{array}{l}\text { Concen- } \\
\text { tration }\end{array}$} & \multicolumn{6}{|c|}{ Matrices tested } & \multicolumn{6}{|c|}{ Addition of components } & \multirow{2}{*}{ Observed effect } & \multirow{2}{*}{ Reference } \\
\hline & & & $\begin{array}{c}\text { UPW } \\
\text { DI }\end{array}$ & DW & GW & SW & SWW & WW & $\begin{array}{l}\text { OM } \\
\text { HA }\end{array}$ & $\mathrm{NO}_{3}^{-}$ & $\mathrm{Cl}^{-}$ & $\mathrm{SO}_{4}{ }^{2-}$ & $\mathrm{HCO}_{3}^{-}$ & Other & & \\
\hline UV & Bisphenol A & $520 \mu \mathrm{M}$ & $\mathrm{X}$ & & & & & $\mathrm{X}$ & & & & & & & Promoting effect & {$[4]$} \\
\hline $\mathrm{UV} / \mathrm{H}_{2} \mathrm{O}_{2}$ & Bisphenol A & $520 \mu \mathrm{M}$ & $\mathrm{X}$ & & & & & $\mathrm{X}$ & & & & & & & Inhibiting effect & {$[4]$} \\
\hline $\mathrm{UV} / \mathrm{H}_{2} \mathrm{O}_{2}$ & Benzoylecgonine & $\begin{array}{c}2.8 \times 10^{-5} \pm \\
4.0 \times 10^{-6} \\
\mathrm{~mol} \mathrm{~L}^{-1}\end{array}$ & $\mathrm{X}$ & & & $\mathrm{X}$ & $\mathrm{X}$ & $\mathrm{X}$ & & & & & & & $\begin{array}{l}\text { Promoting effect } \\
\left(\mathrm{NO}_{3}^{-}\right) \\
\text {Inhibiting effect } \\
(\mathrm{OM})\end{array}$ & [39] \\
\hline $\mathrm{UV} / \mathrm{H}_{2} \mathrm{O}_{2}$ & Benzoylecgonine & $\begin{array}{l}0.6-18.5 \\
\mathrm{mg} \mathrm{L}^{-1}\end{array}$ & $\mathrm{X}$ & & & $\mathrm{X}$ & $\mathrm{X}$ & $\mathrm{X}$ & & & & & & & $\begin{array}{c}\text { Inhibiting effect } \\
\text { (organics, } \\
\text { inorganics) } \\
\end{array}$ & {$[40]$} \\
\hline $\mathrm{UV} / \mathrm{H}_{2} \mathrm{O}_{2}$ & $\begin{array}{c}\text { Atrazine, } \\
\text { sulfamethoxazole, N- } \\
\text { nitrosodimethylamine }\end{array}$ & $\begin{array}{c}0.5-11 \\
\mu \mathrm{M}\end{array}$ & & & & $\mathrm{X}$ & & $\mathrm{X}$ & & & & & & & $\begin{array}{l}\text { Inhibiting effect } \\
\quad(\mathrm{OM})\end{array}$ & [13] \\
\hline 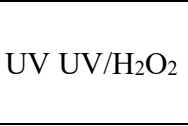 & $\begin{array}{l}\text { Pharmaceuticals, } \\
\text { benzotriazole, mecoprop }\end{array}$ & $\begin{array}{l}\mathrm{ng} \mathrm{L^{-1 }} \text { to } \\
\mu \mathrm{g} \mathrm{L}^{-1} \\
\text { levels }\end{array}$ & & & & & & $X^{*}$ & & & & & & & $\begin{array}{l}\text { Dependent on the } \\
\text { origin }\end{array}$ & {$[20]$} \\
\hline UV & Hydrochlorothiazide & $1 \mu \mathrm{M}$ & $\mathrm{X}$ & & & $\mathrm{X}$ & & $\mathrm{X}$ & & & & & & & $\begin{array}{l}\text { Inhibiting effect } \\
(\mathrm{OM})\end{array}$ & {$[23]$} \\
\hline UV & Pharmaceuticals & $100 \mu \mathrm{g} \mathrm{L}^{-1}$ & $\mathrm{X}$ & & & & & $X$ & $\mathrm{X}$ & $\mathrm{X}$ & $\mathrm{X}$ & $\mathrm{X}$ & $\mathrm{X}$ & & $\begin{array}{c}\text { Promoting effect } \\
\left(\mathrm{NO}_{3}^{-}\right) \\
\text {Inhibiting effect } \\
(\mathrm{HA}, \mathrm{OM})\end{array}$ & {$[24]$} \\
\hline UV & E1, E2, EE2 & $\begin{array}{c}1.3-1.5 \mathrm{mg} \\
\mathrm{L}^{-1}\end{array}$ & & $\mathrm{X}$ & & & & $\mathrm{X}$ & & & & & & & $\begin{array}{l}\text { No noteworthy } \\
\text { differences }\end{array}$ & {$[25]$} \\
\hline $\mathrm{UV} / \mathrm{H}_{2} \mathrm{O}_{2}$ & E1, E2, EE2 & $\begin{array}{l}1.3-1.5 \mathrm{mg} \\
\mathrm{L}^{-1}\end{array}$ & & $\mathrm{X}$ & & & & $\mathrm{X}$ & & & & & & & $\begin{array}{l}\text { Inhibiting effect } \\
\text { (OM, anions) }\end{array}$ & {$[25]$} \\
\hline
\end{tabular}




\begin{tabular}{|c|c|c|c|c|c|c|c|c|c|c|c|c|c|}
\hline UV & $\begin{array}{l}\text { O-phenylphenol, methyl } \\
\text { paraben, propyl paraben, } \\
\text { triclosan, bisphenol A }\end{array}$ & $0.5 \mathrm{mg} \mathrm{L}^{-1}$ & $X$ & & $\mathrm{X}$ & $\mathrm{X}$ & & $\mathrm{X}$ & & & & $\begin{array}{c}\text { Promoting effect } \\
\left(\mathrm{NO}_{3}^{-}\right) \\
\text {Inhibiting effect } \\
\end{array}$ & [29] \\
\hline UV & $\begin{array}{l}\text { Monensin, salinomycin, } \\
\text { narasin }\end{array}$ & $0.5 \mathrm{mg} \mathrm{L}^{-1}$ & $\mathrm{X}$ & & & $X$ & $X$ & & & & & $\begin{array}{l}\text { Promoting effect } \\
\left(\mathrm{OM}, \mathrm{NO}_{3}^{-}\right) \\
\text {Inhibiting effect } \\
\text { (OM depending on } \\
\text { its source) }\end{array}$ & [30] \\
\hline UV & $\begin{array}{c}\text { Pharmaceuticals, } \\
\text { pesticides, caffeine, } \\
\text { triclosan, 2,4- } \\
\text { dichlorophenoxyacetic } \\
\text { acid }\end{array}$ & $150 \mu \mathrm{g} \mathrm{L}^{-1}$ & $\mathrm{X}$ & & & $\mathrm{X}$ & $\mathrm{X}$ & $\mathrm{X}$ & & & & $\begin{array}{l}\text { Promoting effect } \\
\text { (OM for some } \\
\left.\text { compounds, } \mathrm{NO}_{3}^{-}\right) \\
\text {Inhibiting effect } \\
\text { (OM for some } \\
\text { compounds) }\end{array}$ & [15] \\
\hline UV & $\begin{array}{l}\text { Monensin, salinomycin, } \\
\text { narasin, nigericin }\end{array}$ & $\begin{array}{c}0.8-3.0 \\
\mu \mathrm{M} \\
\end{array}$ & $X$ & & $X$ & $X$ & & & & & & $\begin{array}{l}\text { Promoting effect } \\
\left(\mathrm{OM}, \mathrm{NO}_{3}^{-}, \mathrm{Cl}^{-}\right)\end{array}$ & [34] \\
\hline $\mathrm{UV} / \mathrm{H}_{2} \mathrm{O}_{2}$ & $\begin{array}{l}\text { Monensin, salinomycin, } \\
\text { narasin, nigericin }\end{array}$ & $\begin{array}{c}0.8-3.0 \\
\mu \mathrm{M}\end{array}$ & $X$ & & $X$ & $\mathrm{X}$ & & & & & & Inhibiting effect & [34] \\
\hline $\mathrm{UV} / \mathrm{H}_{2} \mathrm{O}_{2}$ & $\begin{array}{c}\text { Pharmaceuticals, } \\
\text { bisphenol A }\end{array}$ & $4 \mu \mathrm{M}$ & $X$ & & $\mathrm{X}$ & $\mathrm{X}$ & & & & & & $\begin{array}{l}\text { Inhibiting effect } \\
\text { (OM and ions) }\end{array}$ & [38] \\
\hline UV & Sulfamethoxazole & $\begin{array}{l}1.0,2.0 \\
5.0 \text { and } 10 \\
\mathrm{mg} \mathrm{L}^{-1}\end{array}$ & $\mathrm{X}$ & & & $\mathrm{X}$ & $\mathrm{X}$ & $\mathrm{X}$ & $\mathrm{X}$ & $\mathrm{X}$ & $\mathrm{X}$ & $\begin{array}{c}\text { Promoting effect } \\
\left(\mathrm{Cl}^{-}, \mathrm{SO}_{4}^{2-}, \mathrm{NO}_{3}^{-}, 5\right. \\
\left.\mathrm{mg} \mathrm{L}^{-1} \text { of } \mathrm{HA}\right) \\
\text { Inhibiting effect } \\
\left(\mathrm{HCO}_{3}^{-}, \mathrm{HA} \text { at }\right. \\
\text { higher } \\
\text { concentrations })\end{array}$ & [41] \\
\hline $\begin{array}{c}\mathrm{UV} \\
\mathrm{UV} / \mathrm{H}_{2} \mathrm{O}_{2}\end{array}$ & Pharmaceuticals & $\begin{array}{c}0.68-1.72 \\
\mu \mathrm{M}\end{array}$ & $\mathrm{X}$ & & & $X^{*}$ & & & & & & $\begin{array}{l}\text { Dependent on the } \\
\text { origin }\end{array}$ & [19] \\
\hline $\begin{array}{c}\mathrm{UV} \\
\mathrm{UV} / \mathrm{H}_{2} \mathrm{O}_{2}\end{array}$ & $\begin{array}{l}\text { Oxytetracycline, } \\
\text { doxycycline, } \\
\text { ciprofloxacin } \\
\end{array}$ & $5 \mu \mathrm{M}$ & $X$ & $\mathrm{X}$ & $X$ & $X$ & & & & & & Inhibiting effect & [35] \\
\hline $\begin{array}{c}\mathrm{UV} \\
\mathrm{UV} / \mathrm{H}_{2} \mathrm{O}_{2}\end{array}$ & $\begin{array}{l}\text { 1-H-Benzotriazole, N,N- } \\
\text { diethyl-m-toluamide } \\
\text { (DEET), chlorophene, 3- } \\
\text { methylindole, nortripty- } \\
\text { line } \mathrm{HCl}\end{array}$ & $1 \mu \mathrm{M}$ & $\mathrm{X}$ & & $\mathrm{X}$ & $\mathrm{X}$ & & & & & & $\begin{array}{l}\text { Inhibiting effect } \\
\quad(\mathrm{OM})\end{array}$ & [42] \\
\hline
\end{tabular}




\begin{tabular}{|c|c|c|c|c|c|c|c|c|c|c|}
\hline $\begin{array}{c}\mathrm{UV} \\
\mathrm{UV} / \mathrm{H}_{2} \mathrm{O}_{2} \\
\end{array}$ & Fungicides & $10 \mu \mathrm{g} \mathrm{L}-1$ & & $X$ & & $\mathrm{X}$ & $\mathrm{X}$ & & $\begin{array}{c}\text { No noteworthy } \\
\text { differences }\end{array}$ & [43] \\
\hline Fenton-like & Bisphenol A & $\begin{array}{l}285-14200 \\
\mu \mathrm{g} \mathrm{L}^{-1}\end{array}$ & $X$ & $\mathrm{X}$ & $X$ & $\mathrm{X}$ & $X$ & & $\begin{array}{c}\text { Promoting effect }\left(\mathrm{Cl}^{-}\right. \\
) \\
\text {Inhibiting effect } \\
\left(\mathrm{OM}, \mathrm{HCO}_{3}^{-}\right)\end{array}$ & [14] \\
\hline $\begin{array}{l}\text { Bio-electro- } \\
\text { Fenton }\end{array}$ & $\begin{array}{l}\text { Ketoprofen, diclofenac, } \\
\text { ibuprofen and naproxen }\end{array}$ & $40 \mu \mathrm{g} \mathrm{L}^{-1}$ & $\mathrm{X}$ & & & & $\mathrm{X}$ & & $\begin{array}{l}\text { Inhibiting effect } \\
\text { (OM, anions) }\end{array}$ & [44] \\
\hline Fenton & Trimethoprim & $0.05 \mathrm{mM}$ & $X$ & & & & $X$ & & $\begin{array}{l}\text { Inhibiting effect } \\
\qquad(\mathrm{OM})\end{array}$ & [45] \\
\hline $\begin{array}{c}\text { Fenton } \\
\text { Photo-Fenton } \\
\mathrm{UV} \\
\mathrm{UV} / \mathrm{H}_{2} \mathrm{O}_{2} \\
\end{array}$ & Prednisolone & $100 \mathrm{mg} \mathrm{L}^{-1}$ & $X$ & & & & $\mathrm{X}$ & & $\begin{array}{l}\text { Inhibiting effect } \\
\text { (organics, } \\
\text { inorganics) }\end{array}$ & [46] \\
\hline $\begin{array}{c}\text { Fenton } \\
\text { Photo-Fenton }\end{array}$ & $\begin{array}{l}\text { Pharmaceuticals, } \\
\text { benzotriazole, mecoprop }\end{array}$ & $\begin{array}{l}\mathrm{ng} \mathrm{L^{-1 }} \text { to } \\
\mu \mathrm{g} \mathrm{L}^{-1} \\
\text { levels }\end{array}$ & & & & & $X$ & & $\begin{array}{l}\text { Dependent on the } \\
\text { origin }\end{array}$ & [20] \\
\hline Photo-Fenton & Tetracycline & $24 \mathrm{mg} \mathrm{L}^{-1}$ & $X$ & & & & $X$ & & $\begin{array}{l}\text { Inhibiting effect } \\
\text { (organics, } \\
\text { inorganics) } \\
\end{array}$ & [37] \\
\hline Photo-Fenton & 62 MPs & $\begin{array}{l}3-66,379 \\
\operatorname{ng~L}^{-1}\end{array}$ & & & & & $X^{*}$ & $\begin{array}{l}\text { EDDS; } \\
\mathrm{H}_{2} \mathrm{SO}_{4}\end{array}$ & $\begin{array}{l}\text { Promoting effect } \\
\text { (EDDS) } \\
\text { Inhibiting effect } \\
\text { (HA) }\end{array}$ & [47] \\
\hline Photo-Fenton & $\begin{array}{l}\text { Pharmaceuticals, } \\
\text { pesticides, estrogens, } \\
\text { triclosan, } \\
\text { hydroxybiphenyl, } \\
\text { caffeine }\end{array}$ & $100 \mu \mathrm{g} \mathrm{L}^{-1}$ & & & & & $X^{*}$ & $\begin{array}{l}\text { EDDS; } \\
\mathrm{H}_{2} \mathrm{SO}_{4}\end{array}$ & $\begin{array}{l}\text { No noteworthy } \\
\text { differences }\end{array}$ & [48] \\
\hline Photo-Fenton & $\begin{array}{l}\text { Pharmaceuticals, } \\
\text { pesticides, estrogens, } \\
\text { triclosan, } \\
\text { hydroxybiphenyl, } \\
\text { caffeine }\end{array}$ & $\begin{array}{l}5 \text { and } 100 \\
\mu \mathrm{g} \mathrm{L}^{-1}\end{array}$ & & & & & $X^{*}$ & $\begin{array}{l}\text { Oxalat } \\
\quad \text { e; } \\
\mathrm{H}_{2} \mathrm{SO}_{4}\end{array}$ & $\begin{array}{l}\text { Promoting effect } \\
\text { (HA, oxalate) }\end{array}$ & [49] \\
\hline Photo-Fenton & Ofloxacin & $10 \mathrm{mg} \mathrm{L}^{-1}$ & $X$ & & & $X$ & $\mathrm{X}$ & & $\begin{array}{l}\text { Inhibiting effect } \\
\left(\mathrm{OM}, \mathrm{Cl}^{-}, \mathrm{SO}_{4}^{2-}\right)\end{array}$ & [50] \\
\hline
\end{tabular}




\begin{tabular}{|c|c|c|c|c|c|c|c|c|c|c|c|c|c|c|c|}
\hline Photo-Fenton & Trimethoprim & $10 \mathrm{mg} \mathrm{L}^{-1}$ & $\mathrm{X}$ & & & $\mathrm{X}$ & $\mathrm{X}$ & $\mathrm{X}$ & & & & & & $\begin{array}{l}\text { Inhibiting effect } \\
(\mathrm{OM}, \text { inorganics) }\end{array}$ & {$[12]$} \\
\hline Fenton & Nonionic surfactants & $1.4 \mathrm{mg} \mathrm{L}^{-1}$ & $\mathrm{X}$ & & & & & $\mathrm{X}$ & & & & & & Inhibiting effect & [51] \\
\hline Photo-Fenton & $\begin{array}{l}\text { Sulfamethoxazole, } \\
\text { clarithromycin }\end{array}$ & $100 \mu \mathrm{g} \mathrm{L}^{-1}$ & $\mathrm{X}$ & & & & $\mathrm{X}$ & $X$ & & & & & & $\begin{array}{l}\text { Inhibiting effect } \\
\left(\mathrm{OM}, \mathrm{Cl}^{-}, \mathrm{SO}_{4}^{2-}\right)\end{array}$ & {$[52]$} \\
\hline Photo-Fenton & $\begin{array}{c}\text { Pharmaceuticals, } \\
\text { pesticides, estrogens, } \\
\text { triclosan, } \\
\text { hydroxybiphenyl, } \\
\text { caffeine }\end{array}$ & $100 \mu \mathrm{g} \mathrm{L}^{-1}$ & & & & & $\mathrm{X}$ & $\mathrm{X}$ & & & & & $\mathrm{H}_{2} \mathrm{SO}_{4}$ & $\begin{array}{l}\text { Promoting effect } \\
\text { (HA) } \\
\text { Inhibiting effect } \\
\left(\mathrm{CO}_{3}^{2-}, \mathrm{HCO}_{3}^{-}\right) \\
\end{array}$ & [53] \\
\hline Fenton & Hydroquinone & $100 \mathrm{mg} \mathrm{L}^{-1}$ & $\mathrm{X}$ & & & & & $\mathrm{X}$ & & & & & & $\begin{array}{c}\text { No noteworthy } \\
\text { differences }\end{array}$ & [54] \\
\hline Fenton & $51 \mathrm{MPs}$ & $\begin{array}{l}\mathrm{ng} \mathrm{L}^{-1}-\mu \mathrm{g} \\
\mathrm{L}^{-1} \text { levels } \\
\end{array}$ & & & & & & $X^{*}$ & & & & & & Inhibiting effect & {$[55]$} \\
\hline Fenton & $\begin{array}{l}\text { Pharmaceuticals, } \\
\text { estrogens, triclosan }\end{array}$ & $\begin{array}{l}\mathrm{ng} \mathrm{L^{-1 }} \text { to } \\
\mu \mathrm{g} \mathrm{L}^{-1} \\
\text { levels }\end{array}$ & & & & & & $X^{*}$ & & & & & & Inhibiting effect & {$[56]$} \\
\hline $\begin{array}{c}\mathrm{UV} / \mathrm{H}_{2} \mathrm{O}_{2} \\
\text { Photo-Fenton }\end{array}$ & $\begin{array}{c}\text { Pharmaceuticals, } \\
\text { methylbenzotriazole, } \\
\text { benzotriazole }\end{array}$ & $2 \mu \mathrm{M}$ & $\mathrm{X}$ & & & $\mathrm{X}$ & & $\mathrm{X}$ & & & & & & $\begin{array}{l}\text { Promoting effect } \\
\left(\mathrm{HA}, \mathrm{CO}_{3}^{2-}, \mathrm{Cl}^{-}\right)\end{array}$ & [57] \\
\hline Photocatalysis & Diclofenac & $\begin{array}{c}5-20 \mathrm{mg} \mathrm{L}^{-} \\
\end{array}$ & $\mathrm{X}$ & & $\mathrm{X}$ & & & $\mathrm{X}$ & & & & & & $\begin{array}{c}\text { Inhibiting effect } \\
\text { (OM, other species) }\end{array}$ & [32] \\
\hline Photocatalysis & Clofibric acid & $1 \mathrm{mg} \mathrm{L}^{-1}$ & $\mathrm{X}$ & & & & & $\mathrm{X}$ & $\mathrm{X}$ & $X$ & $\mathrm{X}$ & $\mathrm{X}$ & $\mathrm{X}$ & $\begin{array}{l}\text { Inhibiting effect } \\
\text { (inorganics) }\end{array}$ & [58] \\
\hline Photocatalysis & $\begin{array}{c}\text { Pharmaceuticals, } \\
\text { pesticides, disinfectants }\end{array}$ & $100 \mu \mathrm{g} \mathrm{L}^{-1}$ & & & & & $\mathrm{X}$ & $X$ & & & & & & Inhibiting effect & [59] \\
\hline $\begin{array}{l}\text { Photocatalysis } \\
\mathrm{UV} / \mathrm{H}_{2} \mathrm{O}_{2}\end{array}$ & Pharmaceuticals & $100 \mu \mathrm{g} \mathrm{L}^{-1}$ & $\mathrm{X}$ & & & & & $\mathrm{X}$ & & & & & & $\begin{array}{l}\text { Inhibiting effect } \\
\left(\mathrm{OM}, \mathrm{CO}_{3}^{2-} \text {, other }\right. \\
\text { anions })\end{array}$ & {$[60]$} \\
\hline Photocatalysis & Propyl paraben & $420 \mu \mathrm{g} \mathrm{L}^{-1}$ & $\mathrm{X}$ & $\mathrm{X}$ & & $\mathrm{X}$ & & $\mathrm{X}$ & & & & & & $\begin{array}{l}\text { Inhibiting effect } \\
\left(\mathrm{HA}, \mathrm{HCO}_{3}^{-}, \mathrm{Cl}^{-}\right) \\
\end{array}$ & {$[61]$} \\
\hline Photocatalysis & $\begin{array}{c}\text { Pharmaceuticals, } \\
\text { pesticides, industrial } \\
\text { compounds } \\
\end{array}$ & $2 \mathrm{mg} \mathrm{L}^{-1}$ & $\mathrm{X}$ & & & & & $\mathrm{X}$ & & & & & & $\begin{array}{l}\text { Inhibiting effect } \\
\text { (OM, ions) }\end{array}$ & {$[62]$} \\
\hline Photocatalysis & E1 & $\underset{1}{1000} \mu \mathrm{g} \mathrm{L}$ & $\mathrm{X}$ & & & & $X$ & $\mathrm{X}$ & & & & & & $\begin{array}{l}\text { Inhibiting effect } \\
\text { (OM, anions) }\end{array}$ & {$[63]$} \\
\hline
\end{tabular}




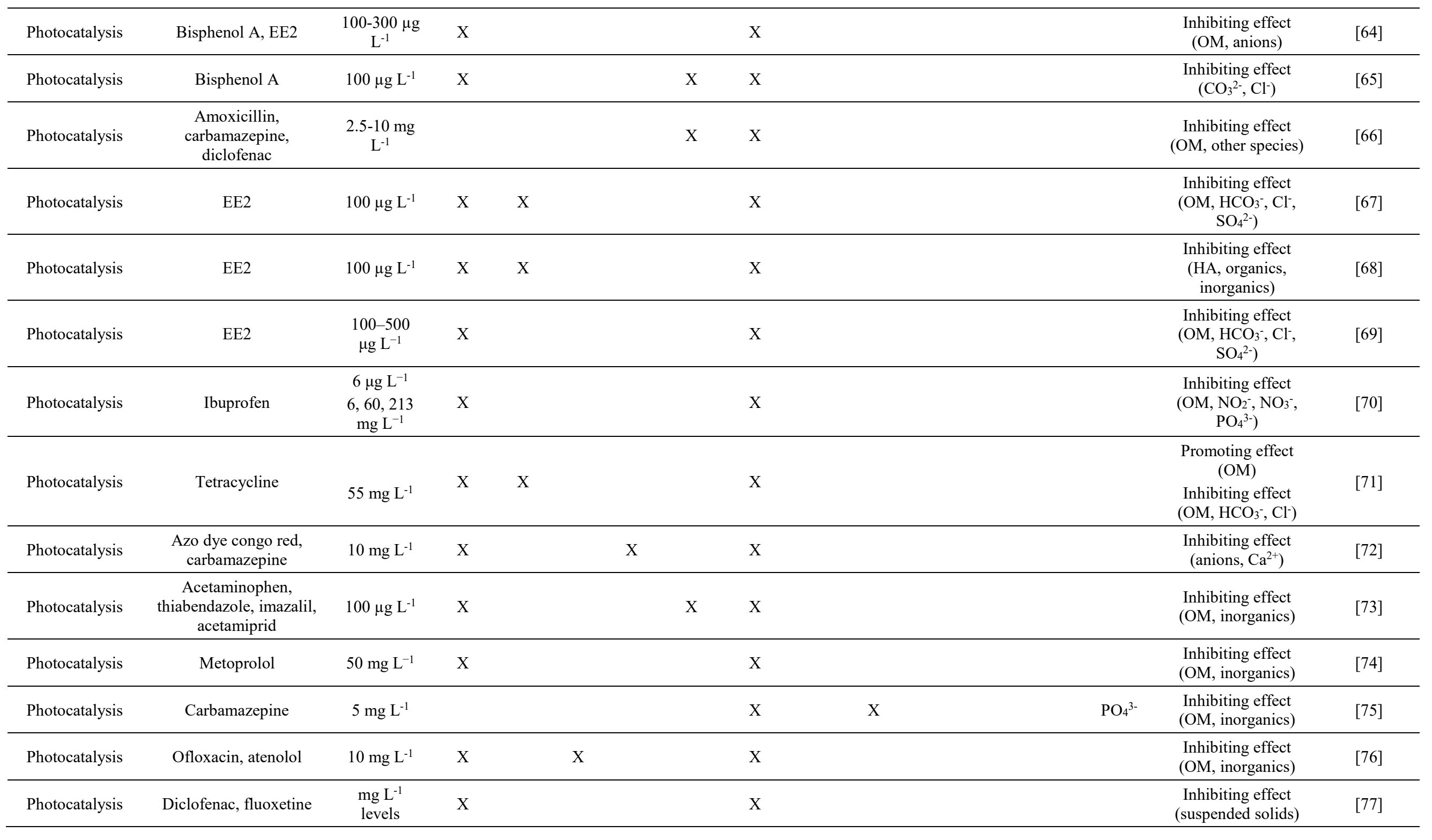




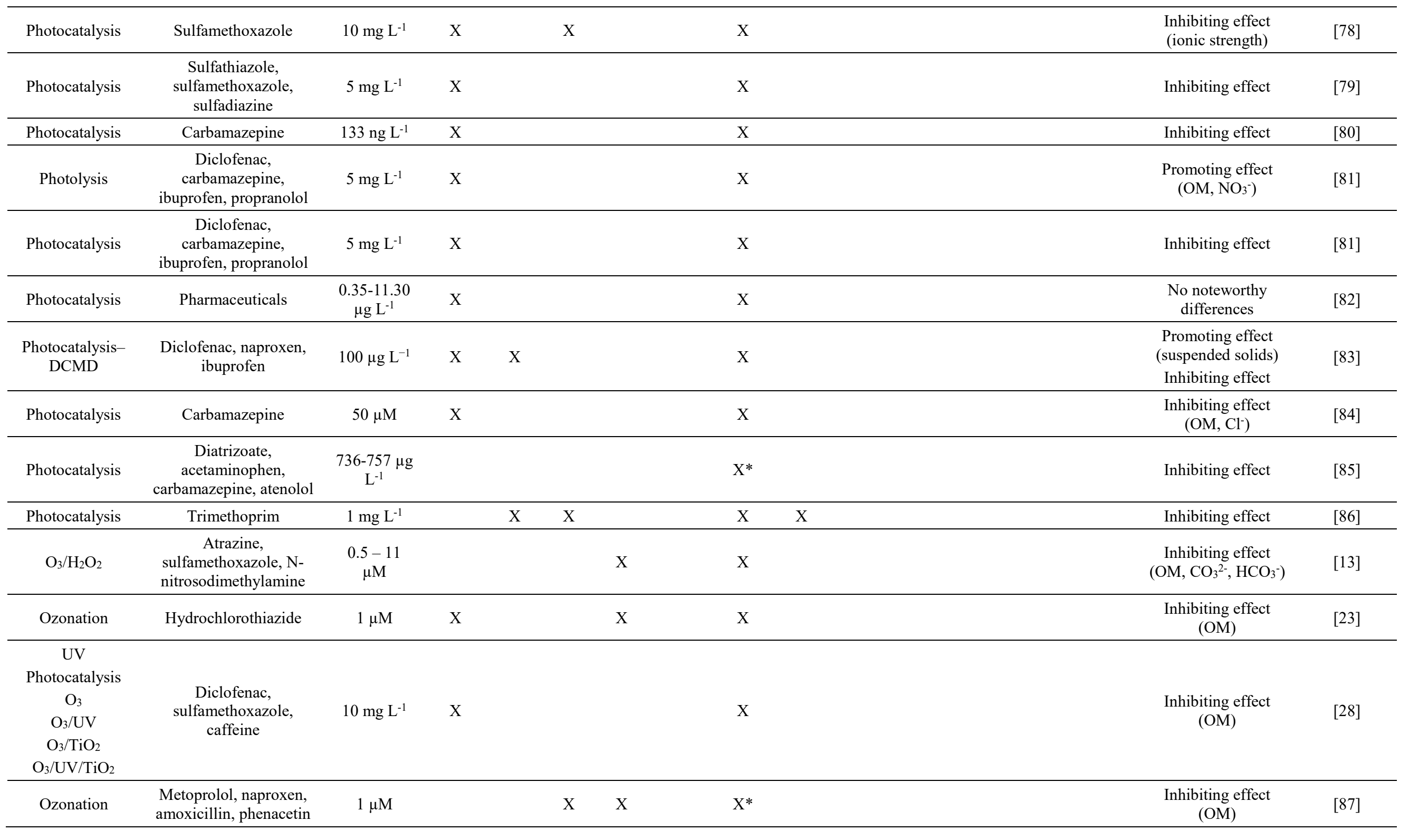




\begin{tabular}{|c|c|c|c|c|c|c|c|c|c|c|c|c|c|c|}
\hline $\begin{array}{c}\text { UV } \\
\text { Photocatalysis } \\
\left(\mathrm{TiO}_{2}\right) \\
\end{array}$ & Acetamiprid & $100 \mu \mathrm{g} \mathrm{L}^{-1}$ & $X$ & & $\mathrm{X}$ & $X$ & & & & & & $\begin{array}{l}\text { HA, } \\
\text { LS, } \\
\text { lignin }\end{array}$ & $\begin{array}{l}\text { Inhibiting effect } \\
\text { (HA) }\end{array}$ & [88] \\
\hline $\begin{array}{c}\text { Photo-Fenton } \\
\text { Photocatalysis } \\
\text { (PS) } \\
\text { UV/PS/Fe } \\
\end{array}$ & Acetamiprid & $100 \mu \mathrm{g} \mathrm{L}^{-1}$ & $\mathrm{X}$ & & $\mathrm{X}$ & $\mathrm{X}$ & & & & & & $\begin{array}{l}\text { HA, } \\
\text { LS, } \\
\text { lignin }\end{array}$ & $\begin{array}{l}\text { Inhibiting effect } \\
\text { (lignin) }\end{array}$ & [88] \\
\hline $\begin{array}{l}\text { Photocatalysis } \\
\qquad \mathrm{O}_{3} / \mathrm{H}_{2} \mathrm{O}_{2} \\
\end{array}$ & $\begin{array}{c}\text { Carbamazepine, } \\
\text { diclofenac }\end{array}$ & $\begin{array}{l}10-1000 \mu \mathrm{g} \\
\mathrm{L}^{-1}\end{array}$ & $\mathrm{X}$ & & & $\mathrm{X}$ & & & & & & & Inhibiting effect & [16] \\
\hline Photo-Fenton & $\begin{array}{c}\text { Carbamazepine, } \\
\text { diclofenac }\end{array}$ & $\begin{array}{c}10-1000 \mu \mathrm{g} \\
\mathrm{L}^{-1}\end{array}$ & $\mathrm{X}$ & & & $\mathrm{X}$ & & & & & & & Promoting effect & [16] \\
\hline $\mathrm{O}_{3}$ & Tetrabromobisphenol & $100 \mathrm{mg} \mathrm{L}^{-1}$ & $\mathrm{X}$ & $\mathrm{X}$ & & $X^{*}$ & $\mathrm{X}$ & $\mathrm{X}$ & $\mathrm{X}$ & $\mathrm{X}$ & $\mathrm{X}$ & & $\begin{array}{l}\text { No noteworthy } \\
\text { differences }\end{array}$ & [89] \\
\hline $\mathrm{O}_{3}$ & Flumequine & $\begin{array}{l}20 \mu \mathrm{g} \mathrm{L}^{-1}- \\
20 \mathrm{mg} \mathrm{L}^{-1}\end{array}$ & $\mathrm{X}$ & $\mathrm{X}$ & & $\mathrm{X}^{*}$ & $\mathrm{X}$ & & $\mathrm{X}$ & $\mathrm{X}$ & $\mathrm{X}$ & $\begin{array}{l}\mathrm{K}^{+} \\
\mathrm{Ca}^{2+} \\
\mathrm{Mg}^{2+}\end{array}$ & $\begin{array}{l}\text { Promoting effect } \\
(\mathrm{OM}) \\
\text { Inhibiting effect } \\
(\mathrm{OM})\end{array}$ & [90] \\
\hline $\begin{array}{c}\mathrm{O}_{3} \\
\mathrm{O}_{3} / \mathrm{H}_{2} \mathrm{O}_{2} \\
\end{array}$ & $\begin{array}{l}\text { Metoprolol, naproxen, } \\
\text { amoxicillin, phenacetin }\end{array}$ & $1 \mu \mathrm{M}$ & $\mathrm{X}$ & & & $\mathrm{X}^{*}$ & & & & & & & $\begin{array}{l}\text { Inhibiting effect } \\
(\mathrm{OM})\end{array}$ & [91] \\
\hline $\begin{array}{l}\text { Photocatalytic } \\
\text { ozonation }\end{array}$ & Diclofenac & $\begin{array}{l}10^{-4} \text { and } \\
10^{-6} \mathrm{M}\end{array}$ & $\mathrm{X}$ & & & $X$ & & & & & & & $\begin{array}{l}\text { Inhibiting effect } \\
\text { (organics, } \\
\text { inorganics) } \\
\end{array}$ & [92] \\
\hline $\mathrm{O}_{3}$ & APIs & $1 \mu \mathrm{g} \mathrm{L}^{-1}$ & & & & $X^{*}$ & & & & & & & $\begin{array}{c}\text { Inhibiting effect } \\
\text { (COD and alkalinity) }\end{array}$ & [93] \\
\hline $\mathrm{O}_{3}$ & Ofloxacin & $22 \mathrm{mg} \mathrm{L}^{-1}$ & & & $\mathrm{X}$ & $\mathrm{X}$ & & & & & & & $\begin{array}{l}\text { Inhibiting effect } \\
(\mathrm{OM})\end{array}$ & [94] \\
\hline $\mathrm{O}_{3}$ & Benzalkonium chloride & $10 \mathrm{mg} \mathrm{L}^{-1}$ & & & $\mathrm{X}$ & $X$ & & & & & & & $\begin{array}{l}\text { Inhibiting effect } \\
(\mathrm{OM})\end{array}$ & [95] \\
\hline $\mathrm{O}_{3}$ & Pesticides & $\underset{1}{5-20} \mathrm{mg} \mathrm{L}^{-}$ & & & $\mathrm{X}$ & $X$ & & & & & & & $\begin{array}{c}\text { Inhibiting effect } \\
\left(\mathrm{COD}, \mathrm{HCO}_{3}^{--}, \mathrm{PO}_{4}^{3-}\right. \\
\left.\mathrm{Cl}^{-}\right)\end{array}$ & [96] \\
\hline $\begin{array}{c}\mathrm{O}_{3} \\
\text { Catalytic } \\
\text { ozonation }\end{array}$ & $\begin{array}{l}\text { Mesoxalic and oxalic } \\
\text { acids }\end{array}$ & $50 \mathrm{mg} \mathrm{L}^{-1}$ & & & & $X$ & & & $\mathrm{X}$ & $\mathrm{X}$ & $\mathrm{X}$ & $\mathrm{PO}_{4}{ }^{3-}$ & $\begin{array}{c}\text { Inhibiting effect } \\
\text { (anions, suspended } \\
\text { solids) }\end{array}$ & [97] \\
\hline $\begin{array}{c}\mathrm{O}_{3} \\
\mathrm{O}_{3} / \mathrm{H}_{2} \mathrm{O}_{2}\end{array}$ & $\begin{array}{l}\text { Sulfamethoxazole, } \\
\text { diclofenac }\end{array}$ & $30 \mathrm{mg} \mathrm{L}^{-1}$ & & & $\mathrm{X}$ & $\mathrm{X}$ & & & & & & & $\begin{array}{c}\text { Inhibiting effect } \\
\left(\mathrm{CO}_{3}^{2-}, \mathrm{HCO}_{3}^{--}, \mathrm{SO}_{4}{ }^{2-}\right. \\
\left., \mathrm{PO}_{4}^{3-}\right)\end{array}$ & [98] \\
\hline
\end{tabular}




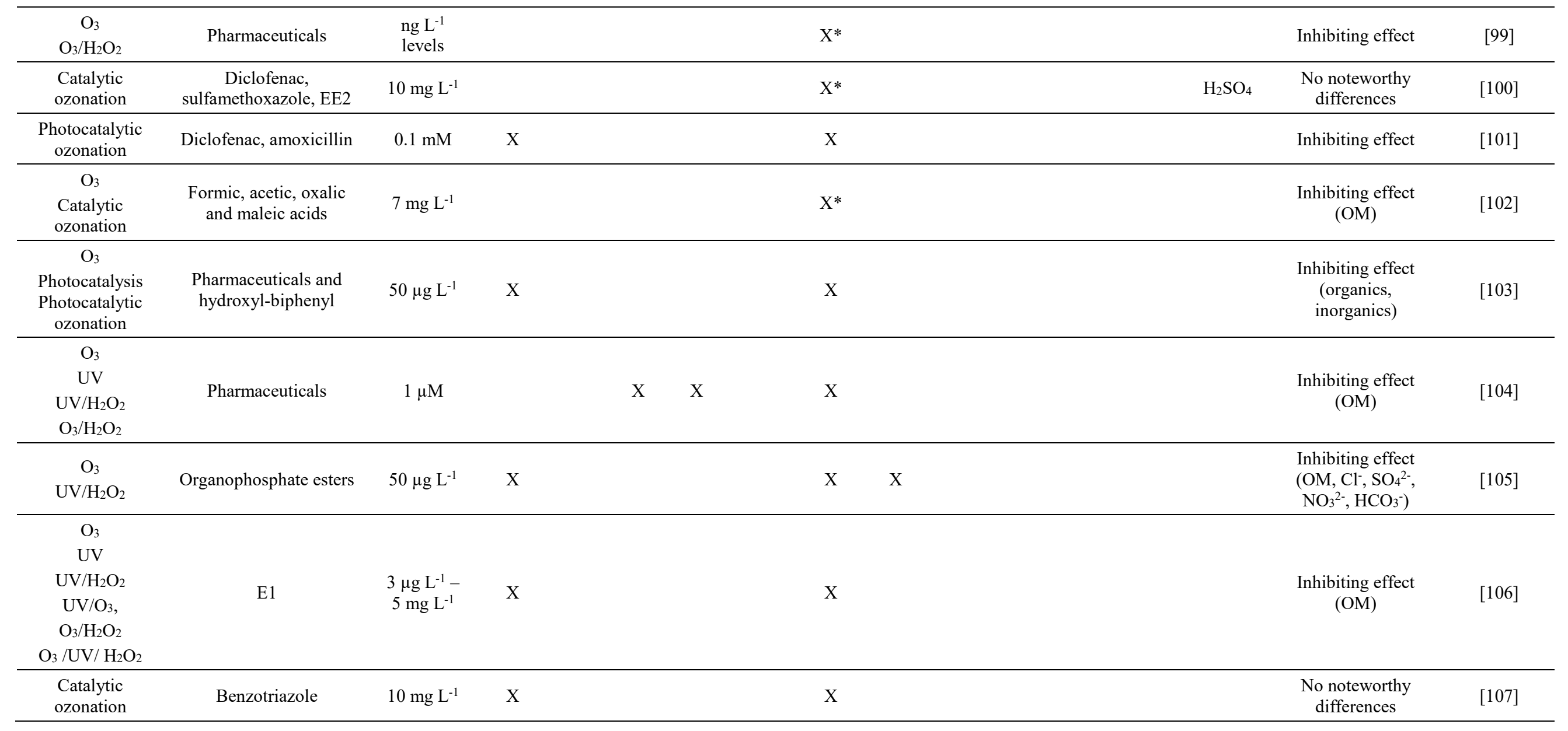

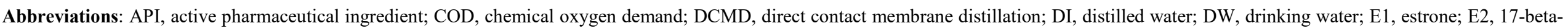

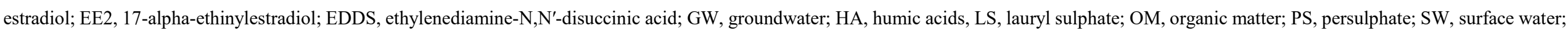
SWW, synthetic wastewater; UPW, ultrapure water; WW, wastewater. 


\subsection{Fenton-based processes}

The conventional Fenton process employs the "Fenton's reagent" [108], a mixture of $\mathrm{Fe}^{2+}$ and $\mathrm{H}_{2} \mathrm{O}_{2}$ that yields $\mathrm{HO}^{\bullet}$ and $\mathrm{Fe}^{3+}$ as reaction products (Reactions 17-18). This reagent combines the use of the fourth most abundant element in the earth's crust, which has environmental compatibility and low-toxicity [109], with the oxidant $\mathrm{H}_{2} \mathrm{O}_{2}$, which self-decomposition leads to non-toxic products $\left(\mathrm{H}_{2} \mathrm{O}\right.$ and $\left.\mathrm{O}_{2}\right)$ [110]. The low cost of the Fenton's reagent and the negligible activation energy, coupled to the simplicity of the process, are attractive advantages. However, the regeneration of $\mathrm{Fe}^{2+}$ under darkness in the conventional Fenton process is very slow and governed by the following reactions (Reactions 19-21) [20].

$\mathrm{Fe}^{2+}+\mathrm{H}_{2} \mathrm{O}_{2} \rightarrow \mathrm{Fe}^{3+}+\mathrm{HO}^{-}+\mathrm{HO}^{\cdot}$

$\mathrm{Fe}^{2+}+\mathrm{HO}^{\cdot} \rightarrow \mathrm{Fe}^{3+}+\mathrm{HO}^{-}$

$\mathrm{HO}^{\bullet}+\mathrm{RH} \rightarrow \mathrm{H}_{2} \mathrm{O}+\mathrm{R}^{\bullet}$

$\mathrm{R}^{\cdot}+\mathrm{Fe}^{3+}+\rightarrow \mathrm{R}^{+}+\mathrm{Fe}^{2+}$

$\mathrm{Fe}^{3+}+\mathrm{H}_{2} \mathrm{O}_{2} \rightarrow \mathrm{Fe}^{2+}+\mathrm{HO}_{2}^{\cdot}+\mathrm{H}^{+}$

The main shortcomings of the Fenton process include: (i) the fast depletion of $\mathrm{Fe}^{2+}$ and the slow regeneration rate; (ii) the amount of sludge produced needing additional treatment; (iii) the complexation of some iron species; (iv) the potential loss of oxidants by scavenging effect or auto-degradation; and (v) the requirement of a pH between 2.5 and 3.0 to achieve optimal performance and below 4.0 to avoid the iron precipitation [111]. The latter originate the need to neutralize the wastewater with bases after treatment, but the consequent raised salt concentration would be deleterious for specific reuses of the treated water, such as for irrigation [47].

Modifications of the Fenton reaction in "Fenton-like" processes using $\mathrm{Fe}^{3+}$ (Reactions 22-23) [112] or zero-valent iron $\left(\mathrm{Fe}^{\circ}\right)$ (Reaction 24) [113] have also been investigated, the former producing peroxyl radicals $\left(\mathrm{HO}_{2}{ }^{\circ}\right)$ and the latter as a source of $\mathrm{Fe}^{2+}$ in the Fenton reaction.

$\mathrm{Fe}^{3+}+\mathrm{H}_{2} \mathrm{O}_{2} \rightarrow \mathrm{H}^{+}+\mathrm{FeOOH}^{2+}$ 
$\mathrm{FeOOH}^{2+} \rightarrow \mathrm{HO}_{2}{ }^{\cdot}+\mathrm{Fe}^{2+}$

$\mathrm{Fe}^{\mathrm{o}}+\mathrm{H}_{2} \mathrm{SO}_{4} \rightarrow \mathrm{Fe}^{2+}+\mathrm{SO}_{4}^{2-}+\mathrm{H}_{2}$

Photo-Fenton based processes are assisted by UV-Vis irradiation, accelerating the regeneration rate of $\mathrm{Fe}^{2+}$ from $\mathrm{Fe}^{3+}$ complexes (Reactions 26-26). The most photoactive complex $[\mathrm{Fe}(\mathrm{OH})]^{2+}$ is predominant at acidic $\mathrm{pH}$, limiting the use of photo-Fenton. Temperature is also an important parameter that has an impact on both Fenton and photo-Fenton reaction rates, since raising the temperature accelerates the oxidation of $\mathrm{Fe}^{2+}$ by $\mathrm{H}_{2} \mathrm{O}_{2}$ (thermal Fenton) and enhances the light absorption coefficient of $\mathrm{Fe}^{3+}$ [44]. However, the increase of temperature may lead to higher leaching of iron and consequent deactivation of catalyst in successive cycles, as well as to the thermal decomposition of $\mathrm{H}_{2} \mathrm{O}_{2}$ to water and oxygen above $40{ }^{\circ} \mathrm{C}$ [108].

$\left[\mathrm{Fe}\left(\mathrm{H}_{2} \mathrm{O}\right)\right]^{3+}+h v \rightarrow \mathrm{Fe}^{2+}+\mathrm{HO}^{\bullet}+\mathrm{H}^{+}$

$[\mathrm{Fe}(\mathrm{OH})]^{2+}+h v \rightarrow \mathrm{Fe}^{2+}+\mathrm{HO}^{\bullet}$

The higher costs of the photo-Fenton process in comparison to the conventional Fenton reaction, due to the use of an irradiation source, are compensated by the lower amount of catalyst required to efficiently generate $\mathrm{HO}^{\circ}$ and by the smaller amount of sludge produced [1], which was reported to be 25 times less in a study dealing with the treatment of landfill leachate by conventional Fenton and photo-Fenton processes [114]. It has been suggested that no supplementary iron is required in wastewater effluents containing at least $1.5 \mathrm{mg} \mathrm{L}^{-1}$ of total iron, to employ the photo-Fenton process $[21,115]$.

Photo-Fenton at neutral $\mathrm{pH}$ has been applied using chelating agents, namely ferrioxalate $\left(\left[\mathrm{Fe}\left(\mathrm{C}_{2} \mathrm{O}_{4}\right)_{3}\right]^{3-}\right)$, ethylenediamine-N, $\mathrm{N}^{\prime}$-disuccinic acid (EDDS), humic acids (HA) and mixing the wastewater effluents with small amounts of influent sample [47-49]. The former is a photosensitive complex with an extended absorption range, enabling the efficient use of solar light. Besides, in comparison to $\mathrm{Fe}^{2+}$ hydroxyl-complexes (Reaction 27), ferrioxalate gives a higher quantum yield of $\mathrm{Fe}^{2+}$ (Reactions 28-29) [116] and generates a higher amount of $\mathrm{HO}^{*}$ 
(Reactions 30-33), by providing additional sources of oxidant $\mathrm{H}_{2} \mathrm{O}_{2}$ and catalyst $\mathrm{Fe}^{2+}$ for the Fenton reaction [49].

$\mathrm{Fe}(\mathrm{OH})_{2}+h v \rightarrow \mathrm{Fe}^{2+}+2 \mathrm{HO}^{*}$

$\left[\mathrm{Fe}\left(\mathrm{C}_{2} \mathrm{O}_{4}\right)_{3}\right]^{3-}+h v \rightarrow \mathrm{Fe}^{2+}+2 \mathrm{C}_{2} \mathrm{O}_{4}^{2-}+\mathrm{C}_{2} \mathrm{O}_{4}^{-}$

$\mathrm{C}_{2} \mathrm{O}_{4}^{--}+\left[\mathrm{Fe}\left(\mathrm{C}_{2} \mathrm{O}_{4}\right)_{3}\right]^{3-} \rightarrow \mathrm{Fe}^{2+}+3 \mathrm{C}_{2} \mathrm{O}_{4}^{2-}+2 \mathrm{CO}_{2}$

$\mathrm{C}_{2} \mathrm{O}_{4}{ }^{--}+\mathrm{O}_{2} \rightarrow 2 \mathrm{CO}_{2}+\mathrm{O}_{2}^{-}$

$\mathrm{O}_{2}^{-}+\mathrm{H}^{+} \rightarrow \mathrm{HO}_{2} \cdot$

$2 \mathrm{HO}_{2}^{\cdot} \rightarrow \mathrm{H}_{2} \mathrm{O}_{2}+\mathrm{O}_{2}$

$\mathrm{H}_{2} \mathrm{O}_{2}+\mathrm{Fe}^{2+} \rightarrow \mathrm{Fe}^{3+}+\mathrm{HO}^{\bullet}+\mathrm{HO}^{-}$

Solar photo-Fenton using EDDS as an iron-complexing agent can be a feasible process to degrade contaminants (phenol, bisphenol A, sulfamethoxazole, carbamazepine and pyrimethanil) from wastewater effluents, even at neutral and slightly alkaline $\mathrm{pH}$ and in the presence of high DOC values [117]. HA can be also used to promote the photo-Fenton reaction due to their characteristics: (i) HA are organic substances resulting from chemical and microbiological transformation of organic matter and are ubiquitous in the environment; (ii) they have a complex chemical structure, which include carboxylic acids, phenolic, alcoholic quinine, amino and amido groups, as well as high amounts of stable free radicals; (iii) HA are able to photoinduce the transformation of non-absorbing organic chemicals due to the absorption of sunlight and consequent generation of $\mathrm{HO}^{*}$, ROS, exited triplet states $\left({ }^{3} \mathrm{HA}^{*}\right)$, singlet oxygen $\left({ }^{1} \mathrm{O}_{2}\right)$ and $\mathrm{H}_{2} \mathrm{O}_{2}$ [49]; they are able to improve the process at natural $\mathrm{pH}$ due to the enhanced reduction of $\mathrm{Fe}(\mathrm{III})$ humate-complexes in comparison with the Fe(III) aquo-complexes [88]. However, HA at high concentrations can also scavenge radicals [88], therefore the overall effect on the MPs removal may be either promoting, neutral or inhibitory. Table 1 summarizes the reports published since 2005 referring the evaluation of matrix effects on Fenton-based processes (more details can be found in Table S3). 
Another approach commonly used in photo-Fenton like processes involves the use of radiation to assist the photo-decarboxylation of ferric carboxylates (Reaction 34) [118].

$\left[\mathrm{Fe}^{3+} \mathrm{L}\right]+h v \rightarrow\left[\mathrm{Fe}^{3+} \mathrm{L}\right]^{*} \rightarrow \mathrm{Fe}^{2+}+\mathrm{L}^{\cdot}$

The photoactive ferric complexes are formed between $\mathrm{Fe}^{3+}$ and carboxylate or polycarboxylate groups, which are functional moieties frequently present in DOM [119]. These are soluble in wastewater under a wide $\mathrm{pH}$ range, avoiding the precipitation of $\mathrm{Fe}^{3+}$ at neutral $\mathrm{pH}$ and the consequent need of acidification and $\mathrm{pH}$ control of Fenton processes. Another main advantage is the higher molar absorption coefficients in the near UV-Vis spectral regions in comparison to the Fe(III) aquo-complexes $[117,119]$. However, such compounds typically able to form photoactive $\mathrm{Fe}^{3+} \mathrm{L}$ (e.g., oxalic acid, lactic acid, quinolinic acid, fusaric acid, pinolenic acid) are usually highly biodegradable and often absent in wastewater effluents [119]. For this reason, the mixing of effluent with small amounts of influent (3:1 ratio) as a source of these substances has been investigated, as a mean to avoid the addition of supplementary chemical reactants during the treatment process [49]. The effectiveness of this approach for the degradation of the MPs is, however, dependent on the concentration ratio of carboxylate or polycarboxylate compounds and the organic load in the water influents [49].

The electro-Fenton process, is an eco-friendly, electrically assisted Fenton process, consisting in the use of a reactor with inert electrodes which are able to electro-regenerate $\mathrm{Fe}^{2+}$ from $\mathrm{Fe}^{3+}$. In such process, the $\mathrm{Fe}^{2+}$ is provided from sacrificial cast iron anodes and the $\mathrm{H}_{2} \mathrm{O}_{2}$ is either added to the reactor or generated in-situ by the two-electron oxygen reduction reaction in an acidic medium (Reaction 35) [111]

$\mathrm{O}_{2}+2 \mathrm{H}^{+}+2 \mathrm{e}^{-} \rightarrow \mathrm{H}_{2} \mathrm{O}_{2}$

The electricity costs of the electro-Fenton (or photo-electro-Fenton) process, similarly to the photo-Fenton process, are overcome by the smaller amount of catalyst required to efficiently generate $\mathrm{HO}^{\circ}$ and by the smaller quantity of sludge produced, in comparison to the conventional Fenton process. 
The water matrix components may raise a negative and/or a positive impact on the effectiveness of Fenton-based processes and the overall result depends on their balance $[12,16,50]$. In complex water matrices containing many species, the degradation of MPs is generally lower than in pure water when Fenton-based processes are employed, implying the use of higher doses of reactants (iron species and $\mathrm{H}_{2} \mathrm{O}_{2}$ ) [51]. The following factors have a negative impact: (i) light scattering inhibiting the photo-reduction of $\mathrm{Fe}^{3+}$; (ii) the scavenging of $\mathrm{HO}$ by water matrix constituents, such as organic acids, NOM (e.g., humic and fulvic acids), inorganic ions (e.g., bicarbonate, carbonate) [120]; and (iii) the formation of complexes (e.g., $\mathrm{FeCl}_{2}{ }^{+}, \mathrm{FeCl}^{2+}$, and $\mathrm{Fe}\left(\mathrm{SO}_{4}\right)_{2}{ }^{-}$) by reaction between iron ions and inorganic anions, reducing the catalytic activity of the free iron species [16]. Specifically, chloride and sulphate can decrease the photo-Fenton reaction rate with MPs by scavenging $\mathrm{HO}^{\circ}$ and producing chlorine and sulphate radicals $\left(\mathrm{Cl}_{2}{ }^{--}\right.$and $\left.\mathrm{SO}_{4}{ }^{--}\right)$, which overall are less reactive than $\mathrm{HO}$. They can also complex the iron species $\left(\mathrm{Fe}^{2+}\right.$ and $\left.\mathrm{Fe}^{3+}\right)$, interfering with the reduction of $\mathrm{Fe}^{3+}$ to $\mathrm{Fe}^{2+}$ that is required to sustain an efficient Fenton mechanism $[12,52]$. Very recently, these species were shown to decrease the conversion of dichlorophenoxyacetic acid from $74.25 \%$ in demineralised water to $70.98 \%$ in the presence of sulphate and $66.65 \%$ in the presence of chloride [121]. In consequence, high organic and inorganic species in water matrices may decrease the removal rates of contaminants [52] and DOC in general, interfering with the degradation pathways and consequently affecting the composition and toxicity of the by-products formed $[12,50]$. For instance, the presence of chloride in the water matrix has been linked to the production of chlorinated transformation byproducts [14]. Other inhibiting effect can arise from the formation of iron complexes with the byproducts generated during the degradation of a certain compound, as observed in the case of prednisolone [46].

In contrast, the following factors have a positive impact on Fenton-based processes: (i) the iron ions naturally occurring in the water matrix may act as an additional source of catalyst for the Fenton reaction; (ii) inherent reductants present in the water matrix (e.g., phenolic compounds) might reduce $\mathrm{Fe}^{3+}$ to $\mathrm{Fe}^{2+}$, increasing the regeneration rate of the catalyst; and (iii) $\mathrm{Fe}^{3+}$ can react 
with compounds containing - $\mathrm{COOH}$ and $-\mathrm{OH}$ groups, originating complexes with higher quantum yield, which might undergo photo-reduction through a ligand-to-metal charge transfer to $\mathrm{Fe}^{2+}[16$, 122]. Although high content of organic species (e.g., $16.5 \mathrm{mg} \mathrm{L}^{-1}$ of DOC) may reduce the removal rates of MPs [52], some studies have demonstrated higher removal rates of MPs in actual wastewaters in comparison to simulated wastewater matrices. In a study where this phenomenon was observed for 15 compounds (pharmaceuticals, estrogens, personal care products, and pesticides), a similar DOC reduction in both matrices suggested that the HA present in the wastewater effluents probably produced solvated electrons and $\mathrm{HO}^{\bullet}$ upon irradiation [53]. In another report, a DOM content approximately 2000 times higher than the concentration of MPs in the wastewater did not denote a shortcoming on their removal rates, since certain species in the DOM could either act as photosensitizers or complex iron to keep it dissolved, promoting the degradation of MPs by the photo-Fenton reaction mechanism [115].

\subsection{Photocatalysis}

Heterogeneous photocatalysis has been extensively reported in the last decades, not only for water/wastewater and air treatment, but also for production of fuels [1]. Heterogeneous photocatalysis is based on the use of wide band-gap semiconductors, which generate conduction band electrons and valence band holes, under irradiation with light energy $(h v)$ equal to or higher than the semiconductor band-gap energy (Reaction 36) $[123,124]$.

$\mathrm{TiO}_{2}+h v \quad \rightarrow \quad \mathrm{e}^{-}+\mathrm{h}^{+}$

The photogenerated conduction band electrons and valence band holes can either recombine to dissipate heat, or migrate to the semiconductor surface, where they can react with species adsorbed on the catalyst surface [123]. The photogenerated valence band holes produce reactive $\mathrm{HO}^{*}$ which are strong oxidizing agents, by reaction with water (Reaction 37 ) and with hydroxide ion under alkaline conditions (Reaction 38), or can also react directly with adsorbed species (Reaction 39) [1]. 
$\mathrm{TiO}_{2}\left(\mathrm{~h}^{+}\right)+\mathrm{H}_{2} \mathrm{O} \rightarrow \mathrm{TiO}_{2}+\mathrm{HO}^{\bullet}+\mathrm{H}^{+}$

$\mathrm{TiO}_{2}\left(\mathrm{~h}^{+}\right)+\mathrm{HO}^{-} \rightarrow \mathrm{TiO}_{2}+\mathrm{HO}^{\cdot}$

$\mathrm{TiO}_{2}\left(\mathrm{~h}^{+}\right)+$AdsSpecies $\rightarrow \mathrm{TiO}_{2}+$ AdsSpecies $^{\bullet+}$

The photogenerated conduction band electrons usually reduce the adsorbed molecular oxygen (and/or adsorbed reducible species) and generate superoxide radicals (Reaction 40), which can further react with protons to produce peroxide radicals (Reaction 41) [123]. The substrate species then can react with the ROS generated (Reaction 42).

$\mathrm{TiO}_{2}\left(\mathrm{e}^{-}\right)+\mathrm{O}_{2} \rightarrow \mathrm{TiO}_{2}+\mathrm{O}_{2}{ }^{-}$

$\mathrm{O}_{2}{ }^{-\cdot}+\mathrm{H}^{+} \rightarrow \mathrm{HO}_{2}{ }^{-}$

$\operatorname{ROS}\left(\mathrm{HO}^{\bullet}, \mathrm{O}_{2}{ }^{\bullet}, \mathrm{HO}_{2}{ }^{\bullet}\right)+$ Species $\rightarrow$ Oxidation products

An ideal photocatalyst should be chemically and photochemically stable, should have a high surface area for the adsorption of the reacting species, a high photon absorption coefficient, a small scattering albedo, be easily available and of low cost whenever possible. Generally, the photodegradation rate of MPs increases with catalyst loading up to an optimum concentration corresponding to the maximum amount of catalyst at which all particles are efficiently irradiated, beyond which the efficiency drops off due to the lower penetration of activating photons through the turbid water [58]. Such process is dependent on reactor geometry, the design of which has been rationalised in terms of optimum dimensionless optical thickness of photoreactors [125]. In the last decades, the most common, commercially available photocatalyst has been $\mathrm{TiO}_{2}$, either in bulk or supported on a substrate, due to its relatively high photoactivity, high mineralization efficiency, low cost and toxicity, high photochemical stability and suitable band-gap energy [1, 124]. $\mathrm{ZnO}$ has also been largely used mainly due to its higher electronic conductivity and near band-gap energy [126]. However, its susceptibility to photo-corrosion limits its use and thus $\mathrm{TiO}_{2}$ is still the most used photocatalyst. Although it has higher performance in an aqueous slurry suspension, the separation of $\mathrm{TiO}_{2}$ from the treated water may in some cases present a minor challenge in industrial scale applications [127]. In consequence, a range of support materials have 
been used for the immobilization of $\mathrm{TiO}_{2}$, including polymers, metals, silica, carbon materials or ceramics [59]. Ideally, an active support must also promote the interaction between the photocatalyst and the contaminants, without hindering the absorption of active photons, and should be resistant to the oxidizing conditions [59].

The two major shortcomings of heterogeneous photocatalysis over $\mathrm{TiO}_{2}$ are: (i) the limited absorption of natural sunlight since near-UV radiation is needed for photo-activation and this part represents only ca. $3-5 \%$ of the solar radiation reaching the earth surface; and (ii) the relatively high rate of electron-hole pairs recombination which reduces the available charges for the redox reactions. Several studies have been published using different approaches to develop photocatalysts that can address the above shortcoming [7], by creating defect structures on the catalyst [128], by metal deposition on the catalyst surface [129], by semiconductor coupling of the energy bands [130] and by doping with metals/non-metal ions [131]. $\mathrm{TiO}_{2}$ combinations with noble metals (e.g., silver, gold and platinum) [63] or with carbon-based materials such as graphene-based materials $[132,133]$, have also been examined. Other carbon materials have been widely studied, including activated carbons [134, 135], carbon xerogels [136], carbon nanotubes [137, 138], graphite [139], and more recently graphitic carbon nitride [140]. The suppression of the recombination of photo-generated charge carriers has been attempted, by adding oxidizing agents/electron acceptors (e.g., inorganic peroxides $\left.\left(\mathrm{S}_{2} \mathrm{O}_{8}{ }^{2-}\right), \mathrm{Fe}^{3+}, \mathrm{H}_{2} \mathrm{O}_{2}\right)$, doping the material with metal ions or anions, by noble metal loading, dye sensitization or using composite semiconductors [126, 141, 142].

The detrimental effect of components co-existing in the water matrix is attributed to the organic and inorganic species intrinsically present in the wastewater [64], including: (i) light attenuation by suspended particles and dissolved species [77]; (ii) the NOM partially consuming HO* and other oxidizing species, thus competing with the degradation of MPs [32, 64-67, 69, 70]; (iii) the anions present in wastewater (e.g., bicarbonate, sulphate and chloride) which scavenge $\mathrm{HO}^{*}$ to form the respective radicals with lower oxidation potential [58, 64-67, 69-72]; and (iv) both organics and inorganics adsorbing onto the catalyst surface, fouling and/or competing for the 
active reaction sites $[63,73-76]$. Table 1 summarizes the reports published since 2005 referring the evaluation of matrix effects on photocatalytic processes (more details can be found in Table S4).

The impact of NOM on the photocatalytic degradation of organic compounds has been recently reviewed [143]. NOM plays an important role in sunlight-induced photochemical processes, generally retarding the photocatalytic degradation of pollutants by the combination of radiation attenuation, competition for adsorption on active sites of the catalyst and surface deactivation, and by scavenging both valence band holes and conduction band electrons [144]. The water matrix may not show an effect on the degradation of the MPs, but may strongly affect the rate of mineralization, as shown in a study on solar $\mathrm{TiO}_{2}$ photocatalytic oxidation of a mixture of four pharmaceuticals (atenolol, hydrochlorothiazide, ofloxacin and trimethoprim) in a synthetic effluent [145]. The impact of the water matrix on the photocatalytic degradation of clofibric acid resulted in a strong decrease of the photocatalytic activity resulting from the competition of NOM, for active sites on the catalyst surface and for reactive species [58]. UV light attenuation plays an additional significant role on the reduction of the rate of degradation of MPs in wastewater.

Inorganic salts in the water matrix $\left(\mathrm{NaCl}, \mathrm{FeCl}_{3}, \mathrm{FeCl}_{2}, \mathrm{AlCl}_{3}, \mathrm{CaCl}_{2}\right)$ can have negative impact on the photocatalyst activity, with a generally more pronounced deactivation effects observed at higher salt concentrations [58]. The deactivation of the $\mathrm{TiO}_{2}$ catalyst by inorganic species has been linked to the competition for free radicals and to the blockage of the active sites on the catalyst surface [58]. Sulphate and carbonate anions might cause strong catalyst deactivation, since both species are strong ROS scavengers, whereas sodium chloride can produce ambiguous effects on the photocatalytic activity of $\mathrm{TiO}_{2}$, depending on the salt concentration [58]. The $\mathrm{pH}$ and the ionic strength of the wastewater play important roles on the degree of catalyst agglomeration in a suspension, which impact on the effective surface area of the photocatalyst [78] and on the rate of photon absorption [146]. High $\mathrm{pH}$ and/or ionic strength of the aqueous solution might result in a higher agglomeration of $\mathrm{TiO}_{2}$, decreasing the effective surface area of the photocatalyst $[147,148]$. This phenomenon has been observed for the photocatalytic 
degradation of sulphonamides, whose removal was favoured at acidic $\mathrm{pH}$ [78-80]. The photocatalytic degradation of clofibric acid was shown to be inhibited by chloride ions at low concentrations, which adsorbed on the $\mathrm{TiO}_{2}$ surface reducing the available active sites. This is justified by the acidic nature of the contaminant and the positively charged surface of the catalyst, resulting from the sample $\mathrm{pH}$ lower than the point of zero charge $\left(\mathrm{pH}_{\mathrm{PZC}}\right)$ of $\mathrm{TiO}_{2}$ [58]. At high concentration of $\mathrm{NaCl}$, the ionic strength was the dominant factor of the photocatalytic efficiency, since the electric double layer become more compressed and the clofibric acid could easily reach the catalyst surface [58].

Phosphate can affect positively the degradation of pollutants by generating the reactive radical $\mathrm{H}_{2} \mathrm{PO}_{4}{ }^{\circ}$ in the presence of holes (Reaction 43 ) which favours the photocatalytic degradation of carbamazepine over $\mathrm{TiO}_{2}[72]$ :

$\mathrm{h}^{+}+\mathrm{H}_{2} \mathrm{PO}_{4}^{-} \rightarrow \mathrm{H}_{2} \mathrm{PO}_{4}^{-}$

The impact of coexisting substances on the photocatalytic degradation of bisphenol A was studied under simulated solar light irradiation and using bismuth tungstate $\left(\mathrm{Bi}_{2} \mathrm{WO}_{6}\right)$ as catalyst, suggesting that photogenerated holes are predominant in the reaction system [149]. The degradation of bisphenol A was accelerated in the presence of a low concentration of HA (1 mg $\mathrm{L}^{-1}$ ), while a hindrance was found at concentrations higher than $5 \mathrm{mg} \mathrm{L}^{-1}$. The presence of anions (nitrate, chloride, sulphate and bicarbonate) and cations (sodium, potassium, calcium and magnesium) led to inhibitory effects, the latter being ascribed to the chloride resulting from the addition of the chloride salts of each cation [149]. At solution $\mathrm{pH}$ lower than $8.7\left(\mathrm{pH}_{\mathrm{PZC}}\right.$ of $\mathrm{Bi}_{2} \mathrm{WO}_{6}$ ), the positively charged surface of the catalyst attracted anions, decreasing the free active sites and diminishing the reaction rate of bisphenol A. Sulphate had a much stronger inhibition effect than chloride, nitrate and bicarbonate, due to its double charge and larger molecular size which increases the steric hindrance [149]. A minor impact was observed for bicarbonate and nitrate ions, the latter favouring the reaction rate at low concentrations, which can be explained by its photolysis and consequent production of $\mathrm{HO}^{*}$ [149]. At high salt concentrations, nitrate could be adsorbed on the catalyst surface, competing for the active sites with the target pollutant, 
while bicarbonate scavenged $\mathrm{HO}^{*}$, producing weakly oxidizing carbonate radicals. The impact of bicarbonate is more significant when the photocatalytic degradation of the target contaminant follows $\mathrm{HO}^{\bullet}$ attack, rather than hole oxidation. On the contrary, the presence of inorganic $\mathrm{Fe}^{3+}$ ion in the water and the use of $\mathrm{H}_{2} \mathrm{O}_{2}$ oxidative reagent played different effects depending on their concentrations. At concentrations lower than $0.01 \mathrm{mmol} \mathrm{L}^{-1} \mathrm{Fe}^{3+}$ or $1 \mathrm{mmol} \mathrm{L}^{-1} \mathrm{H}_{2} \mathrm{O}_{2}$, there was no effect; at concentrations in the range of $0.01-0.1 \mathrm{mmol} \mathrm{L}^{-1}$ of $\mathrm{Fe}^{3+}$ or in the range of $0.1-$ 3 mmol L-1 of $\mathrm{H}_{2} \mathrm{O}_{2}$, a suppression of the photogenerated holes (the main oxidizing species by $\mathrm{Bi}_{2} \mathrm{WO}_{6}$ ) was observed; however, higher concentrations of these interfering species enhanced the degradation rate of bisphenol A due to the generation of $\mathrm{HO}^{*}$ produced by $\mathrm{Fe}(\mathrm{OH})^{2+}$ under UV irradiation or by photolysis of $\mathrm{H}_{2} \mathrm{O}_{2}$ [149].

\subsection{Ozone-based processes}

Ozonation is an AOT widely applied for the purification of drinking water due to the power of $\mathrm{O}_{3}$ as disinfectant and oxidant. Ozonation has also been used for the treatment of either raw wastewaters, as pre-treatment, or secondary wastewater effluents, as post-treatment, to minimize the release of MPs into the receiving waters [89]. In Switzerland, full-scale UWWTPs have already implemented ozonation as a post-treatment process, aiming $80 \%$ average removal of target organic MPs [150].

The transformation of organic substances by ozonation occurs by either reaction with molecular $\mathrm{O}_{3}$ or reaction with less selective $\mathrm{HO}^{*}$, resulting from the decomposition of $\mathrm{O}_{3}$ at neutral and alkaline $\mathrm{pH}$ [13]. In comparison to molecular $\mathrm{O}_{3}$, which is a selective oxidant attacking predominantly electron-rich organic moieties (phenols, anilines, olefins, sulphur, and amine moieties), $\mathrm{HO}^{*}$ are non-selective radicals, more reactive than ozone. The contribution of each pathway depends on the $\mathrm{O}_{3}$ and $\mathrm{HO}^{*}$ exposures (i.e., $\int\left[\mathrm{O}_{3}\right] \mathrm{d} t$ and $\int\left[\mathrm{HO}^{*}\right] \mathrm{d} t$ ) and second order reaction rate constants (Reaction 44-51) [151, 152]. In many cases, high $\mathrm{pH}$ values favour the degradation efficiency due to the decomposition of $\mathrm{O}_{3}$ into $\mathrm{HO}^{\bullet}[153]$. 


$$
\begin{aligned}
& \mathrm{O}_{3}+\mathrm{HO}^{-} \rightarrow \mathrm{HO}_{2}^{-}+\mathrm{O}_{2} \quad \text { (basic } \mathrm{pH} \text { ) } \\
& \mathrm{O}_{3}+\mathrm{HO}_{2}{ }^{-} \rightarrow \mathrm{HO}^{\bullet}+\mathrm{O}_{2}{ }^{-}+\mathrm{O}_{2} \\
& \mathrm{O}_{3}+\mathrm{O}_{2}^{\cdot-} \rightarrow \mathrm{O}_{3}{ }^{\cdot-}+\mathrm{O}_{2} \\
& \mathrm{O}_{3}{ }^{\cdot-}+\mathrm{H}^{+} \leftrightarrow \mathrm{HO}_{3} \cdot \quad(\mathrm{pH}<8) \\
& \mathrm{HO}_{3}{ }^{\cdot} \rightarrow \mathrm{HO}^{*}+\mathrm{O}_{2} \quad(\mathrm{pH}<8) \\
& \mathrm{O}_{3}{ }^{--} \leftrightarrow \mathrm{O}^{*}+\mathrm{O}_{2} \quad(\mathrm{pH}>8) \\
& \mathrm{O}^{\bullet}+\mathrm{H}_{2} \mathrm{O} \rightarrow \mathrm{HO}^{\bullet}+\mathrm{HO}^{-} \quad(\mathrm{pH}>8) \\
& \mathrm{HO}^{\bullet}+\mathrm{O}_{3} \rightarrow \mathrm{HO}_{2}{ }^{\bullet}+\mathrm{O}_{2}
\end{aligned}
$$

Ozonation is an oxidation process that can take place at both the gas-liquid interface and in the bulk liquid, depending on the concentration of the reactants and on the Hatta number [154]. Therefore, the polarity can play an important role in the reaction rate, since non-polar organic compounds tend to accumulate at the interface and be more reactive, while more polar or dissociated substances remain in the bulk liquid [155].

$\mathrm{O}_{3}$ decomposition is fast during the initial phase $(\mathrm{t}<20 \mathrm{~s})$ of natural water ozonation, known as “instantaneous ozone demand", while during the second phase $(\mathrm{t}>20 \mathrm{~s})$ it follows an apparent first-order rate law attributed to radical-type chain reactions, during which $\mathrm{HO}^{*}$ are generated [156]. NOM and carbonate/bicarbonate ions interfere with the rate of $\mathrm{O}_{3}$ decomposition depending on their concentrations and $\mathrm{pH}$, affecting the yield of $\mathrm{HO}^{*}$ [157]. Besides the scavenging effect of $\mathrm{HO}$ by $\mathrm{NOM}[13,23,87,90-95]$ and carbonate/bicarbonate $[13,92,93,97$, 98], other anions (e.g., chloride, phosphate, sulphate) can also act as ozonation inhibitors [97, 98]. The main mechanism of $\mathrm{O}_{3}$ decomposition and generation of $\mathrm{HO}^{*}$ in wastewater is the direct reaction with specific reactive moieties of the NOM (e.g., phenolic, amino and olefinic groups), considering that the initiation step of the radical chain reaction between $\mathrm{O}_{3}$ and hydroxide anions has a small rate constant [156]. The reactions of $\mathrm{O}_{3}$ with DOM (Reactions 52-55) are summarized as the follows $[158,159]$. 
$\mathrm{O}_{3}+\mathrm{DOM}_{\text {direct }} \rightarrow$ products

$\mathrm{O}_{3}+\mathrm{DOM}_{\text {initiator }} \rightarrow \mathrm{HO}^{*}$

$\mathrm{HO}^{\bullet}+\mathrm{DOM}_{\text {promoter }} \rightarrow \cdots \rightarrow \mathrm{O}_{2}{ }^{\cdot}$

$\mathrm{HO}^{\bullet}+\mathrm{DOM}_{\text {inhititor }} \rightarrow$ products

Both the concentration and the composition of DOC determine the rate of decomposition of aqueous $\mathrm{O}_{3}$, therefore $\mathrm{DOC}$ is a crucial water quality parameter that is monitored to normalize the dosing of $\mathrm{O}_{3}$ [156]. Table 1 summarizes the reports published since 2005 referring the evaluation of matrix effects on ozone-based processes (more details can be found in Table S5). The $\mathrm{O}_{3}$ dose required to degrade the antibiotic ofloxacin was strongly affected by the matrix (synthetic water vs wastewater effluent), showing the competition between the NOM and the target pharmaceutical for $\mathrm{O}_{3}$ and suggesting that certain moieties of NOM present in wastewater were preferably attacked [94]. Even when the degradation rate of the organic MPs is not affected, total organic carbon (TOC) removal can be significantly affected due to the refractory nature of the organic matter, as observed in synthetic effluents treated by ozonation [145].

The impact of the inorganic ions (chloride, sulphate and bicarbonate, potassium, calcium and magnesium) or extracts of NOM, and the type of water matrices (ultrapure, river water, influent and effluent wastewaters) on the removal of flumequine by ozonation, has been shown to be insignificant [90]. However, rice straw and pig manure NOM extracts, promoted the oxidation of the target pollutant [90]. The scavenging of NOM and carbonate/bicarbonate on $\mathrm{HO}^{\bullet}$ in different water matrices containing similar DOC and bicarbonate contents demonstrated different DOM reactivity [13]. Moreover, the higher carbonate-alkalinity led to slower kinetics of pCBA removal, ascribed to the slower kinetics of $\mathrm{O}_{3}$ decomposition due to the inhibition by the carbonate/bicarbonate ions in the water [13].

Another study reported that nitrate enhanced the degradation rate of phenazone by ozone, whereas other anions (chlorine, sulphate and bicarbonate) reduced the rate, following the order: sulphate $>$ chloride $>$ bicarbonate [160]. While the scavenging of HO* by bicarbonate is well-known, the 
lower degradation rate of phenazone in the presence of sulphate and chloride was attributed to the formation of weaker $\mathrm{Cl}_{2}{ }^{--}$and $\mathrm{SO}_{4}{ }^{--}$radicals [160].

The main drawback of the ozonation process is the generally limited rate of DOC mineralization and consequent accumulation of unknown reaction by-products, resulting from the incomplete oxidation of the target compounds and from the reaction with the water matrix constituents [161]. Undesirable toxic oxidation by-products include nitrosamines (e.g., N-Nitrosodimethylamine, NDMA), bromate and formaldehyde [161]. Although these by-products may increase the toxicity of the treated wastewater, they are typically biodegradable and therefore a biological postfiltration is usually applied [161]. The limited extent of DOC mineralization can be overcome by adding catalysts or $\mathrm{H}_{2} \mathrm{O}_{2}$.

The peroxone process combining $\mathrm{O}_{3} / \mathrm{H}_{2} \mathrm{O}_{2}$ accelerates the conversion of $\mathrm{O}_{3}$ to $\mathrm{HO}$, which can decrease the reaction time needed to degrade the MPs [13]. The degradation efficiency of the MPs reaches a maximum at certain concentration of $\mathrm{H}_{2} \mathrm{O}_{2}$ beyond which inhibition occurs [160]. Two $\mathrm{HO}^{\bullet}$ are produced from the reaction between two $\mathrm{O}_{3}$ and one $\mathrm{H}_{2} \mathrm{O}_{2}$ molecule, therefore the ratio between the $\mathrm{H}_{2} \mathrm{O}_{2}$ supply rate and the $\mathrm{O}_{3}$ absorption rate should be 0.5 or slightly higher [162]. A low $\mathrm{H}_{2} \mathrm{O}_{2}$ dose can catalytically decompose $\mathrm{O}_{3}$ to generate a substantial amount of $\mathrm{HO}^{*}$, which favours the oxidation of MPs, whereas an excessive $\mathrm{H}_{2} \mathrm{O}_{2}$ dose can favour the reaction with $\mathrm{HO}^{*}$ to form a weaker hydroperoxyl radical $\left(\mathrm{HO}_{2}{ }^{\circ}\right)[160]$.

The use of heterogeneous catalysts or photocatalysts is an attractive solution in ozonation, since the combination of two or more AOTs can lead to higher removal rates in comparison to the single processes. Usually, the application of ozonation alone rarely lead to complete mineralization of MPs, since some reaction intermediates, including specific carboxylic acids, may not be easily destroyed by $\mathrm{O}_{3}$ or by its produced oxidizing radicals. When the organic compounds are not completely degraded, the partial oxidation may produce by-products that are more toxic than the parent pollutants $[163,164]$. Thus, the addition of catalysts in catalytic ozonation can improve the oxidation efficiency of ozone and also its potential to convert oxidation by-products into $\mathrm{CO}_{2}$ [100]. The most widely used catalysts include transition metal oxides $\left(\mathrm{TiO}_{2}, \mathrm{MnO}_{2}, \mathrm{Al}_{2} \mathrm{O}_{3}\right.$, 
$\mathrm{FeOOH}$, and $\left.\mathrm{CeO}_{2}\right)$, metals $(\mathrm{Cu}, \mathrm{Ru}, \mathrm{Pt}$ and $\mathrm{Co})$ on supports $\left(\mathrm{SiO}_{2}, \mathrm{TiO}_{2}, \mathrm{Al}_{2} \mathrm{O}_{3}, \mathrm{CeO}_{2}\right.$ and activated carbon), zeolites modified with metals, activated carbon and natural minerals [165].

Recently, photocatalytic ozonation has been studied as an alternative to photocatalysis and ozonation due to the increased production of $\mathrm{HO}^{*}$ through the formation of an ozonide radical $\left(\mathrm{O}_{3}{ }^{\bullet-}\right)$ in the adsorption layer of a semiconductor (e.g., $\left.\mathrm{TiO}_{2}\right)$ and lower electron-hole recombination, in comparison to ozonation and photocatalysis, respectively [1]. Specifically, the $\mathrm{O}_{3}{ }^{--}$species (Reaction 56) generated from the reaction of ozone with the semiconductor electrons react with $\mathrm{H}^{+}$in the solution, forming $\mathrm{HO}_{3}{ }^{\cdot}$ radicals (Reaction 57) which then evolve to produce oxygen and $\mathrm{HO}^{*}\left(\right.$ Reaction 58). In this scenario, it must be also considered that $\mathrm{HO}^{\circ}$ can react with ozone (Reaction 59). When ozone is completely consumed, dissolved $\mathrm{O}_{2}$ can accept the semiconductor conduction band electrons, generating $\mathrm{O}_{2}{ }^{--}$(Reaction 60), which in turn can be protonated (Reaction 61 ). $\mathrm{HO}_{2}{ }^{\circ}$ radicals can also originate $\mathrm{HO}^{*}$, according to the pathway shown by Reactions 62-63 [166].

$$
\begin{aligned}
& \mathrm{O}_{3}+\mathrm{e}^{-} \rightarrow \mathrm{O}_{3}^{\cdot-} \\
& \mathrm{O}_{3}^{\cdot-}+\mathrm{H}^{+} \rightarrow \mathrm{HO}_{3}^{\cdot} \\
& \mathrm{HO}_{3}^{\cdot} \rightarrow \mathrm{O}_{2}+\mathrm{HO}^{\cdot} \\
& \mathrm{HO}^{\cdot}+\mathrm{O}_{3} \rightarrow \mathrm{O}_{2}+\mathrm{HO}_{2}^{\cdot} \\
& \mathrm{O}_{2}+\mathrm{e}^{-} \rightarrow \mathrm{O}_{2}^{\cdot-} \\
& \mathrm{O}_{2}^{\cdot-}+\mathrm{H}^{+} \rightarrow \mathrm{HO}_{2}^{\cdot} \\
& 2 \mathrm{HO}_{2}^{\cdot} \rightarrow \mathrm{H}_{2} \mathrm{O}_{2}+\mathrm{O}_{2} \\
& \mathrm{H}_{2} \mathrm{O}_{2}+\mathrm{O}_{2}^{-} \rightarrow \mathrm{HO}^{\cdot}+\mathrm{HO}^{-}+\mathrm{O}_{2}
\end{aligned}
$$

Another possible reaction pathway has been proposed by Kopf et al. [167]. These authors suggested that the photocatalytic ozonation reactions are initiated by an electron transfer from $\mathrm{TiO}_{2}$ to $\mathrm{O}_{2}$ (Reactions 64-67), followed by reaction of $\mathrm{O}_{2}{ }^{--}$with $\mathrm{O}_{3}$ (Reaction 68), giving place to Reactions 57-58, as well as to Reactions 69-72. 
Charge separation:

$\mathrm{TiO}_{2}+h v \rightarrow \mathrm{h}^{+}+\mathrm{e}^{-}$

Charge transfer of positive charge:

$\mathrm{h}^{+}+\mathrm{H}_{2} \mathrm{O} \rightarrow \mathrm{HO}^{\bullet}+\mathrm{H}^{+}$

Electron transfer and further reactions:

$\mathrm{e}^{-}+\mathrm{O}_{2} \rightarrow \mathrm{O}_{2}{ }^{--}$

$\mathrm{O}_{2}{ }^{--}+\mathrm{H}^{+} \rightleftarrows \mathrm{HO}_{2}{ }^{\cdot}$

$\mathrm{O}_{3}+\mathrm{O}_{2}{ }^{\cdot-} \rightarrow \mathrm{O}_{3}{ }^{\cdot-}+\mathrm{O}_{2}$

$\mathrm{O}_{3}{ }^{\cdot-}+\mathrm{H}^{+} \rightleftarrows \mathrm{HO}_{3}{ }^{\cdot}$

$\mathrm{HO}_{3}{ }^{\circ} \rightarrow \mathrm{HO}^{*}+\mathrm{O}_{2}$

Oxidation of the organic compound R:

$\mathrm{HO}^{\bullet}+\mathrm{R}-\mathrm{H} \rightarrow \mathrm{R}^{\bullet}+\mathrm{H}_{2} \mathrm{O}$

or

$\mathrm{HO}^{\bullet}+\mathrm{R} \rightarrow \mathrm{R}^{\bullet}-\mathrm{OH}$

There are some factors that can affect the photocatalytic ozonation process, some of them similar to those affecting the single processes, such as the ozone dosage, $\mathrm{pH}$ and nature of the photocatalyst. The TOC removal can increase with the ozone dosage, but low ozone dosages are economically more attractive [168]. The $\mathrm{pH}$ of the wastewater has a stronger influence on the ozonation reactions, and may impact the degradation pathways and the kinetics in the reaction process, which can also occur in the photocatalytic ozonation process $[169,170]$. The synergistic effect between both processes can reduce the treatment costs and reaction time under optimum operating conditions (e.g., ozone concentration, the catalyst properties, the loading in the reactor and the usage of more cost-efficient and long-lasting UV sources, such as UV LEDs) [165]. Catalytic and photocatalytic ozonation has been studied for the removal of pharmaceuticals in 
effluents from UWWTPs, however the available data about the impact of water matrix are still unclear. Catalytic ozonation was more efficient than ozonation to degrade mesoxalic and oxalic acids, being almost unaffected by the presence of the inorganic anions or suspended solids. Catalytic ozonation of oxalic acid using copper oxide supported on mesoporous silica as catalyst in the presence of inorganic anions $\left(\mathrm{HCO}_{3}{ }^{-}, \mathrm{PO}_{4}{ }^{3-}, \mathrm{Cl}^{-}\right.$and $\left.\mathrm{SO}_{4}{ }^{2-}\right)$, was inhibited only in the presence of $\mathrm{PO}_{4}{ }^{3-}$, while ozonation alone was almost inhibited by the suspended solids and strongly depended on presence of these inorganic anions [97]. In turn, in other work dealing with the degradation of carboxyl acids (formic, acetic, oxalic and maleic acid), the copper-catalysed continuous ozonation was strongly influenced by the water matrix, ascribing the negative effect to the complexation with organic matter reducing the availability of metal as catalyst [102]. Although the reaction time needed to reach $99 \%$ conversion of 3 compounds (diclofenac, sulfamethoxazole and caffeine) was similar, the removal rates were slightly slower in wastewater effluents than in ultrapure water, by catalytic and photocatalytic ozonation in the presence of $\mathrm{TiO}_{2}$ [28]. The degradation of diclofenac and amoxicillin by photocatalytic ozonation, using $\mathrm{TiO}_{2}$ as photocatalyst, was similar in both ultrapure and wastewater, however, the oxamic acid formed as by-product was refractory to photocatalytic ozonation in the case of spiked wastewater effluents [101]. Another study on the degradation of diclofenac by $\mathrm{TiO}_{2}$-photocatalytic ozonation showed that it was only slightly affected by the organic-inorganic matter of the urban wastewater [92].

\section{Future challenges and conclusions}

Wastewater quality is critical for the performance of AOTs, namely for those here reviewed: photolysis, $\mathrm{UV} / \mathrm{H}_{2} \mathrm{O}_{2}$, Fenton-based processes, photocatalysis, and ozone-based processes. The efficiency of each process results from the complex interplay of inhibitory and promoting effects originated by the water matrix constituents. Wastewater components leading to inhibitory effects on the removal of MPs include NOM (light attenuation; scavenging effects; generation of byproducts; adsorption to catalyst in photocatalytic processes); and inorganic anions (scavenging effects; formation of less active radicals; iron complexation in the case of Fenton; adsorption to 
the catalyst surface or decrease of its effective surface area, in the case of photocatalytic processes). Promoting effects can result from NOM originating ROS, which enhance indirect photolysis; from nitrate ions producing ROS in the case of photolysis; iron ions as additional source of catalyst in Fenton-based processes; and phenolic or other compounds containing $\mathrm{COOH}$ and $-\mathrm{OH}$ groups, which can regenerate the catalyst. However, it is difficult to understand and discriminate the role of each single component. Table 2 summarizes the inhibitory and promoting mechanisms of different wastewater components, aiming to provide a guide on the most suitable treatment as function of the wastewater composition. The available information on the water matrix effects on the removal efficiency of MPs in UWWTPs effluents is still limited and more studies are needed to enlighten the mechanisms and the impact of the main components of the water.

Table 2. Summary of inhibitory (-) and promoting (+) effects of wastewater components, affecting the efficiency of the processes discussed in this review, namely photolysis, $\mathrm{UV} / \mathrm{H}_{2} \mathrm{O}_{2}$, Fenton-based, photocatalysis, and $\mathrm{O}_{3}$-based processes.

\begin{tabular}{|c|c|c|c|c|c|}
\hline & Photolysis & $\mathbf{U V} / \mathbf{H}_{2} \mathbf{O}_{2}$ & $\begin{array}{c}\text { Fenton- } \\
\text { based }\end{array}$ & $\begin{array}{l}\text { Heterogeneous } \\
\text { photocatalysis }\end{array}$ & $\mathrm{O}_{3}$-based \\
\hline $\begin{array}{l}\text { Organic matter } \\
\text { Humic acids }\end{array}$ & $+/-$ & $+/-$ & - & $+/-$ & - \\
\hline Inorganic ions & $+/-$ & $+/-$ & $+/-$ & - & - \\
\hline $\mathrm{NO}_{3}^{-}$ & + & + & & - & \\
\hline $\mathrm{NO}_{2}^{-}$ & & & & - & \\
\hline $\mathrm{PO}_{4}^{3-}$ & & & & - & - \\
\hline $\mathrm{Cl}^{-}$ & + & & $+/-$ & - & - \\
\hline $\mathrm{SO}_{4}^{2-}$ & + & & - & - & - \\
\hline $\mathrm{HCO}_{3}^{-}$ & - & & - & - & - \\
\hline $\mathrm{CO}_{3}^{-}$ & & & - & - & - \\
\hline $\mathrm{Ca}^{2+}$ & & & & - & \\
\hline Iron ions & & & + & & \\
\hline
\end{tabular}




\begin{tabular}{l|l|l|l|l|l}
\hline $\begin{array}{l}\text { Phenolic compounds } \\
\text { (containing-COOH } \\
\text { and-OH groups }\end{array}$ & & & + & & \\
\hline $\mathrm{pH} /$ ionic strength & & & & - & \\
\hline $\begin{array}{l}\text { Number of papers } \\
(2005-2018)\end{array}$ & 19 & 18 & 20 & 32 & 24 \\
\hline
\end{tabular}

On the other hand, it is well known that removal efficiencies of MPs depend on their chemical nature and on the AOT under study, but limited information is available on the effect of wastewater coexisting substances on the elimination of different types of substances by different AOTs. For instance, under UV, $\mathrm{UV} / \mathrm{H}_{2} \mathrm{O}_{2}$, and photo-Fenton, gabapentin and metformin were found as the most recalcitrant compounds from a set of 8 MPs, which followed the same order of degradation [57]. Another report on the degradation of pharmaceuticals showed the same trend for UV-C radiation, heterogeneous photocatalysis, Fenton and photo-Fenton systems (amoxicillin $>$ naproxen $>$ metoprolol $>$ phenacetin), but metoprolol was the most recalcitrant in the ozonebased processes [91], showing that the removal depends also on the MP nature. A recent study on UV/chlorine treatment showed that the degradation of MPs having electron-withdrawing groups (e.g., $-\mathrm{NO}_{2},-\mathrm{Cl},-\mathrm{F}$ ) was largely attributed to $\mathrm{HO}^{*}$, while the degradation of those containing electron-donating groups (e.g., phenol, aniline, alkyl-/alkoxy aromatics, or olefins) was highly ascribed to other reactive species such as $\mathrm{Cl}^{\circ}, \mathrm{Cl}_{2}{ }^{-}$and $\mathrm{ClO}^{\circ}$ [6]. In the same study, it was shown that the scavenging of $\mathrm{NOM}$ on $\mathrm{ClO}^{*}$ was much higher than that observed on $\mathrm{HO}^{*}$ and $\mathrm{Cl}^{\circ}$, suggesting that the removal of MPs that are readily degradable by $\mathrm{ClO}^{*}$ can be largely inhibited by the presence of NOM. On the contrary, alkaline components were ascribed to scavenge HO• and $\mathrm{Cl}^{\circ}$ at higher extent and thus the MPs degraded primarily by these radicals are those which removal is most inhibited by alkalinity [6].

Moreover, the scarce data available on the effects of wastewater components on the removal of MPs with different chemical nature by hydroxyl radical-mediated AOTs show ambiguous results. For example, a better performance was reported for $\mathrm{UV} / \mathrm{H}_{2} \mathrm{O}_{2}$ to degrade several organophosphate esters and some of them (chlorinated and one aliphatic) were recalcitrant to ozonation, but the 
presence of HA improved only the ozonation process, with an opposite trend observed in $\mathrm{UV} / \mathrm{H}_{2} \mathrm{O}_{2}$ treatment [105]. On the contrary, the same order of degradation rates $\left(\mathrm{UV}<\mathrm{UV} / \mathrm{H}_{2} \mathrm{O}_{2}\right.$ $<$ Fenton $<$ solar irradiation $<$ photo-Fenton) was observed regardless of the type of WW analysed, in a study comparing the effluents from activated sludge, moving bed bioreactor and coagulationflocculation treatments [20].

Besides interfering with the process performance, the water matrix might also have an impact on the production and on the nature of the transformation by-products. The degradation of MPs is usually accompanied by the formation of numerous transformation by-products through unaccountable pathways and the matrix components may impact these pathways. For example, reactions in the presence of chlorides are prone to originate toxic chlorinated by-products. However, more studies addressing the effect of diverse water matrix components on the transformation products, are still needed to better understand their possible impacts. Other important parameters that are important to consider for the evaluation of the impact of the water matrix are the biodegradability and the toxicity of the effluents that are generated. A thorough investigation on the nature of the wastewater components is required not only to improve the performance of advanced water treatment systems, but also to minimize the formation of toxic reaction by-products, to enhance the biodegradability of the treated effluents and to reduce the ecotoxicity of the treated effluents. Complete mineralization of the organic matter is difficult and in general not needed if the by-products formed are biodegradable and non-toxic. Standard biodegradability and toxicity tests may be used to establish the levels of treatment needed to achieve a safe effluent.

Future research on treatment technologies should consider the complex interactions between matrix constituents and the oxidative species formed, aiming to maximize the performance of AOTs, since lower efficiencies and higher costs could be expected in real case scenario. With this review, we attempted to provide a comprehensive data analysis of the available studies using real water matrices, showing the lack of systematic understanding of the role of each wastewater component for all AOTs herein reviewed and encouraging the need of more studies applying real 
matrices. Although complex, the role of matrix constituents is fundamental for future employment of AOTs in industrial-scale water treatment processes to remove MPs and to protect the environment.

\section{Acknowledgments}

This work was financially supported by Projects: POCI-01-0145-FEDER-006984 - Associate Laboratory LSRE-LCM funded by European Regional Development Fund (ERDF) through COMPETE2020-Programa Operacional Competitividade e Internacionalização (POCI) - and by national funds through FCT - Fundação para a Ciência e a Tecnologia; Project POCI-01-0145FEDER-030521 funded by ERDF funds through COMPETE2020 - POCI and by national funds (PIDDAC) through FCT/MCTES; and Project NORTE-01-0145-FEDER-031049 funded by ERDF funds through NORTE 2020 and by national funds (PIDDAC) through FCT/MCTES. NFFM acknowledge the research grant from FCT (PD/BD/114318/2016), with financing from the European Social Fund and the Human Potential Operational Programme. The authors would like to acknowledge the financial support provided by COST-European Cooperation in Science and Technology, to the COST Action ES1403: New and emerging challenges and opportunities in wastewater reuse (NEREUS). Disclaimer: The content of this article is the authors' responsibility and neither COST nor any person acting on its behalf is responsible for the use, which might be made of the information contained in it. 


\section{References}

[1] A.R. Ribeiro, O.C. Nunes, M.F.R. Pereira, A.M.T. Silva, An overview on the advanced oxidation processes applied for the treatment of water pollutants defined in the recently launched Directive 2013/39/EU, Environ. Int., 75 (2015) 33-51.

[2] M.O. Barbosa, N.F.F. Moreira, A.R. Ribeiro, M.F.R. Pereira, A.M.T. Silva, Occurrence and removal of organic micropollutants: An overview of the watch list of EU Decision 2015/495, Water Res., 94 (2016) 257-279.

[3] J.C.G. Sousa, A.R. Ribeiro, M.O. Barbosa, M.F.R. Pereira, A.M.T. Silva, A review on environmental monitoring of water organic pollutants identified by EU guidelines, J. Hazard. Mater., 344 (2018) 146-162.

[4] M. Neamtu, F.H. Frimmel, Degradation of endocrine disrupting bisphenol A by $254 \mathrm{~nm}$ irradiation in different water matrices and effect on yeast cells, Water Res., 40 (2006) 3745-3750.

[5] L. Lian, B. Yao, S. Hou, J. Fang, S. Yan, W. Song, Kinetic Study of Hydroxyl and Sulfate Radical-Mediated Oxidation of Pharmaceuticals in Wastewater Effluents, Environ. Sci. Technol., 51 (2017) 2954-2962.

[6] K. Guo, Z. Wu, C. Shang, B. Yao, S. Hou, X. Yang, W. Song, J. Fang, Radical Chemistry and Structural Relationships of PPCP Degradation by UV/Chlorine Treatment in Simulated Drinking Water, Environ. Sci. Technol., 51 (2017) 10431-10439.

[7] R. Dewil, D. Mantzavinos, I. Poulios, M.A. Rodrigo, New perspectives for Advanced Oxidation Processes, J. Environ. Manage., 195 (2017) 93-99.

[8] I. García-Fernández, S. Miralles-Cuevas, I. Oller, S. Malato, P. Fernández-Ibáñez, M.I. PoloLópez, Inactivation of E. coli and E. faecalis by solar photo-Fenton with EDDS complex at neutral pH in municipal wastewater effluents, J. Hazard. Mater., (2018).

[9] I. García-Fernández, I. Fernández-Calderero, M.I. Polo-López, P. Fernández-Ibáñez, Disinfection of urban effluents using solar $\mathrm{TiO}_{2}$ photocatalysis: A study of significance of dissolved oxygen, temperature, type of microorganism and water matrix, Catal. Today, 240 (2015) 30-38.

[10] I. Michael-Kordatou, C. Michael, X. Duan, X. He, D.D. Dionysiou, M.A. Mills, D. FattaKassinos, Dissolved effluent organic matter: Characteristics and potential implications in wastewater treatment and reuse applications, Water Res., 77 (2015) 213-248.

[11] M. Wang, Y. Chen, Generation and characterization of DOM in wastewater treatment processes, Chemosphere, 201 (2018) 96-109.

[12] I. Michael, E. Hapeshi, V. Osorio, S. Perez, M. Petrovic, A. Zapata, S. Malato, D. Barceló, D. Fatta-Kassinos, Solar photocatalytic treatment of trimethoprim in four environmental matrices at a pilot scale: Transformation products and ecotoxicity evaluation, Sci. Total Environ., 430 (2012) $167-173$.

[13] I.A. Katsoyiannis, S. Canonica, U. von Gunten, Efficiency and energy requirements for the transformation of organic micropollutants by ozone, $\mathrm{O}_{3} / \mathrm{H}_{2} \mathrm{O}_{2}$ and $\mathrm{UV} / \mathrm{H}_{2} \mathrm{O}_{2}$, Water Res., 45 (2011) 3811-3822. 
[14] A. Outsiou, Z. Frontistis, R.S. Ribeiro, M. Antonopoulou, I.K. Konstantinou, A.M.T. Silva, J.L. Faria, H.T. Gomes, D. Mantzavinos, Activation of sodium persulfate by magnetic carbon xerogels $(\mathrm{CX} / \mathrm{CoFe})$ for the oxidation of bisphenol A: Process variables effects, matrix effects and reaction pathways, Water Res., 124 (2017) 97-107.

[15] Y. Wang, F.A. Roddick, L. Fan, Direct and indirect photolysis of seven micropollutants in secondary effluent from a wastewater lagoon, Chemosphere, 185 (2017) 297-308.

[16] M. Tokumura, A. Sugawara, M. Raknuzzaman, M. Habibullah-Al-Mamun, S. Masunaga, Comprehensive study on effects of water matrices on removal of pharmaceuticals by three different kinds of advanced oxidation processes, Chemosphere, 159 (2016) 317-325.

[17] C. Postigo, C. Sirtori, I. Oller, S. Malato, M.I. Maldonado, M. López de Alda, D. Barceló, Solar transformation and photocatalytic treatment of cocaine in water: Kinetics, characterization of major intermediate products and toxicity evaluation, Appl. Catal. B, 104 (2011) 37-48.

[18] J. Radjenović, C. Sirtori, M. Petrović, D. Barceló, S. Malato, Solar photocatalytic degradation of persistent pharmaceuticals at pilot-scale: Kinetics and characterization of major intermediate products, Appl. Catal. B, 89 (2009) 255-264.

[19] O.S. Keen, K.G. Linden, Degradation of antibiotic activity during $\mathrm{UV} / \mathrm{H}_{2} \mathrm{O}_{2}$ advanced oxidation and photolysis in wastewater effluent, Environ. Sci. Technol., 47 (2013) 13020-13030.

[20] S. Giannakis, F.A. Gamarra Vives, D. Grandjean, A. Magnet, L.F. De Alencastro, C. Pulgarin, Effect of advanced oxidation processes on the micropollutants and the effluent organic matter contained in municipal wastewater previously treated by three different secondary methods, Water Res., 84 (2015) 295-306.

[21] N. De la Cruz, L. Esquius, D. Grandjean, A. Magnet, A. Tungler, L.F. de Alencastro, C. Pulgarin, Degradation of emergent contaminants by $\mathrm{UV}, \mathrm{UV} / \mathrm{H}_{2} \mathrm{O}_{2}$ and neutral photo-Fenton at pilot scale in a domestic wastewater treatment plant, Water Res., 47 (2013) 5836-5845.

[22] O. Legrini, E. Oliveros, A.M. Braun, Photochemical processes for water treatment, Chem. Rev., 93 (1993) 671-698.

[23] F.J. Real, J.L. Acero, F.J. Benitez, G. Roldán, L.C. Fernández, Oxidation of hydrochlorothiazide by UV radiation, hydroxyl radicals and ozone: Kinetics and elimination from water systems, Chem. Eng. J., 160 (2010) 72-78.

[24] Y. Zhang, J. Zhang, Y. Xiao, V.W. Chang, T.T. Lim, Direct and indirect photodegradation pathways of cytostatic drugs under UV germicidal irradiation: Process kinetics and influences of water matrix species and oxidant dosing, J. Hazard. Mater., 324 (2017) 481-488.

[25] B. Cedat, C. de Brauer, H. Metivier, N. Dumont, R. Tutundjan, Are UV photolysis and $\mathrm{UV} / \mathrm{H}_{2} \mathrm{O}_{2}$ process efficient to treat estrogens in waters? Chemical and biological assessment at pilot scale, Water Res., 100 (2016) 357-366.

[26] M. Schmitt, P.R. Erickson, K. McNeill, Triplet-State Dissolved Organic Matter Quantum Yields and Lifetimes from Direct Observation of Aromatic Amine Oxidation, Environ. Sci. Technol., 51 (2017) 13151-13160.

[27] W.A. Arnold, One electron oxidation potential as a predictor of rate constants of Ncontaining compounds with carbonate radical and triplet excited state organic matter, Environmental Science: Processes \& Impacts, 16 (2014) 832-838. 
[28] F.J. Beltrán, A. Aguinaco, J.F. García-Araya, Application of Ozone Involving Advanced Oxidation Processes to Remove Some Pharmaceutical Compounds from Urban Wastewaters, Ozone Sci. Eng., 34 (2012) 3-15.

[29] G. Castro, I. Rodriguez, M. Ramil, R. Cela, Evaluation of nitrate effects in the aqueous photodegradability of selected phenolic pollutants, Chemosphere, 185 (2017) 127-136.

[30] P. Sun, S.G. Pavlostathis, C.H. Huang, Photodegradation of veterinary ionophore antibiotics under UV and solar irradiation, Environ. Sci. Technol., 48 (2014) 13188-13196.

[31] R. Andreozzi, M. Raffaele, P. Nicklas, Pharmaceuticals in STP effluents and their solar photodegradation in aquatic environment, Chemosphere, 50 (2003) 1319-1330.

[32] A. Achilleos, E. Hapeshi, N.P. Xekoukoulotakis, D. Mantzavinos, D. Fatta-Kassinos, Factors affecting diclofenac decomposition in water by UV-A/ $\mathrm{TiO}_{2}$ photocatalysis, Chem. Eng. J., 161 (2010) 53-59.

[33] P.J. Chen, E.J. Rosenfeldt, S.W. Kullman, D.E. Hinton, K.G. Linden, Biological assessments of a mixture of endocrine disruptors at environmentally relevant concentrations in water following $\mathrm{UV} / \mathrm{H}_{2} \mathrm{O}_{2}$ oxidation, Sci. Total Environ., 376 (2007) 18-26.

[34] H. Yao, P. Sun, D. Minakata, J.C. Crittenden, C.H. Huang, Kinetics and modeling of degradation of ionophore antibiotics by UV and UV/ $\mathrm{H}_{2} \mathrm{O}_{2}$, Environ. Sci. Technol., 47 (2013) 4581-4589.

[35] F. Yuan, C. Hu, X. Hu, D. Wei, Y. Chen, J. Qu, Photodegradation and toxicity changes of antibiotics in UV and UV/ $\mathrm{H}_{2} \mathrm{O}_{2}$ process, J. Hazard. Mater., 185 (2011) 1256-1263.

[36] B. Verma, J.V. Headley, R.D. Robarts, Behaviour and fate of tetracycline in river and wetland waters on the Canadian Northern Great Plains, J. Environ. Sci. Health., Part A, 42 (2007) 109-117.

[37] I.R. Bautitz, R.F.P. Nogueira, Degradation of tetracycline by photo-Fenton process-Solar irradiation and matrix effects, J. Photochem. Photobiol. A: Chem., 187 (2007) 33-39.

[38] C. Baeza, D.R. Knappe, Transformation kinetics of biochemically active compounds in lowpressure UV photolysis and $\mathrm{UV} / \mathrm{H}_{2} \mathrm{O}_{2}$ advanced oxidation processes, Water Res., 45 (2011) 45314543.

[39] D. Russo, D. Spasiano, M. Vaccaro, K.H. Cochran, S.D. Richardson, R. Andreozzi, G. Li Puma, N.M. Reis, R. Marotta, Investigation on the removal of the major cocaine metabolite (benzoylecgonine) in water matrices by $\mathrm{UV}_{254} / \mathrm{H}_{2} \mathrm{O}_{2}$ process by using a flow microcapillary film array photoreactor as an efficient experimental tool, Water Res., 89 (2016) 375-383.

[40] D. Spasiano, D. Russo, M. Vaccaro, A. Siciliano, R. Marotta, M. Guida, N.M. Reis, G. Li Puma, R. Andreozzi, Removal of benzoylecgonine from water matrices through $\mathrm{UV}_{254} / \mathrm{H}_{2} \mathrm{O}_{2}$ process: Reaction kinetic modeling, ecotoxicity and genotoxicity assessment, J. Hazard. Mater., 318 (2016) 515-525.

[41] M.V. Mouamfon, W. Li, S. Lu, Z. Qiu, N. Chen, K. Lin, Photodegradation of sulphamethoxazole under UV-light irradiation at 254 nm, Environ. Technol., 31 (2010) 489-494. 
[42] F.J. Benitez, J.L. Acero, F.J. Real, G. Roldan, E. Rodriguez, Modeling the photodegradation of emerging contaminants in waters by $\mathrm{UV}$ radiation and $\mathrm{UV} / \mathrm{H}_{2} \mathrm{O}_{2}$ system, J. Environ. Sci. Health., Part A, 48 (2013) 120-128.

[43] M. Celeiro, R. Facorro, T. Dagnac, V.J.P. Vilar, M. Llompart, Photodegradation of multiclass fungicides in the aquatic environment and determination by liquid chromatography-tandem mass spectrometry, Environ. Sci. Pollut. R., 24 (2017) 19181-19193.

[44] H. Nadais, X. Li, N. Alves, C. Couras, H.R. Andersen, I. Angelidaki, Y. Zhang, Bio-electroFenton process for the degradation of Non-Steroidal Anti-Inflammatory Drugs in wastewater, Chem. Eng. J., 338 (2018) 401-410.

[45] S. Wang, J. Wang, Trimethoprim degradation by Fenton and Fe(II)-activated persulfate processes, Chemosphere, 191 (2018) 97-105.

[46] A.M. Díez, A.S. Ribeiro, M.A. Sanromán, M. Pazos, Optimization of photo-Fenton process for the treatment of prednisolone, Environ. Sci. Pollut. R., (2018) in press.

[47] N. Klamerth, S. Malato, A. Aguera, A. Fernandez-Alba, Photo-Fenton and modified photoFenton at neutral $\mathrm{pH}$ for the treatment of emerging contaminants in wastewater treatment plant effluents: a comparison, Water Res., 47 (2013) 833-840.

[48] N. Klamerth, S. Malato, A. Aguera, A. Fernandez-Alba, G. Mailhot, Treatment of municipal wastewater treatment plant effluents with modified photo-Fenton as a tertiary treatment for the degradation of micro pollutants and disinfection, Environ. Sci. Technol., 46 (2012) 2885-2892.

[49] N. Klamerth, S. Malato, M.I. Maldonado, A. Agüera, A. Fernández-Alba, Modified photoFenton for degradation of emerging contaminants in municipal wastewater effluents, Catal. Today, 161 (2011) 241-246.

[50] I. Michael, E. Hapeshi, J. Acena, S. Perez, M. Petrovic, A. Zapata, D. Barcelo, S. Malato, D. Fatta-Kassinos, Light-induced catalytic transformation of ofloxacin by solar Fenton in various water matrices at a pilot plant: mineralization and characterization of major intermediate products, Sci. Total Environ., 461-462 (2013) 39-48.

[51] M. Pagano, A. Lopez, A. Volpe, G. Mascolo, R. Ciannarella, Oxidation of nonionic surfactants by Fenton and $\mathrm{H}_{2} \mathrm{O}_{2} / \mathrm{UV}$ processes, Environ. Technol., 29 (2008) 423-433.

[52] P. Karaolia, I. Michael, I. Garcia-Fernandez, A. Aguera, S. Malato, P. Fernandez-Ibanez, D. Fatta-Kassinos, Reduction of clarithromycin and sulfamethoxazole-resistant Enterococcus by pilot-scale solar-driven Fenton oxidation, Sci. Total Environ., 468-469 (2014) 19-27.

[53] N. Klamerth, L. Rizzo, S. Malato, M.I. Maldonado, A. Aguera, A.R. Fernandez-Alba, Degradation of fifteen emerging contaminants at $\mathrm{mg} \mathrm{L}^{-1}$ initial concentrations by mild solar photoFenton in MWTP effluents, Water Res., 44 (2010) 545-554.

[54] V.N. Lima, C.S.D. Rodrigues, L.M. Madeira, Application of the Fenton's process in a bubble column reactor for hydroquinone degradation, Environ. Sci. Pollut. R., (2017).

[55] E.B. Estrada-Arriaga, J.E. Cortes-Munoz, A. Gonzalez-Herrera, C.G. Calderon-Molgora, M. de Lourdes Rivera-Huerta, E. Ramirez-Camperos, L. Montellano-Palacios, S.L. GeloverSantiago, S. Perez-Castrejon, L. Cardoso-Vigueros, A. Martin-Dominguez, L. Garcia-Sanchez, Assessment of full-scale biological nutrient removal systems upgraded with physico-chemical 
processes for the removal of emerging pollutants present in wastewaters from Mexico, Sci. Total Environ., 571 (2016) 1172-1182.

[56] G.T. Chi, J. Churchley, K.D. Huddersman, Pilot-Scale Removal of Trace Steroid Hormones and Pharmaceuticals and Personal Care Products from Municipal Wastewater Using a Heterogeneous Fenton's Catalytic Process, Int. J. Chem. Eng., 2013 (2013) 1-10.

[57] M. Neamţu, D. Grandjean, A. Sienkiewicz, S. Le Faucheur, V. Slaveykova, J.J.V. Colmenares, C. Pulgarín, L.F. de Alencastro, Degradation of eight relevant micropollutants in different water matrices by neutral photo-Fenton process under $\mathrm{UV}_{254}$ and simulated solar light irradiation - A comparative study, Appl. Catal. B, 158-159 (2014) 30-37.

[58] N. Rioja, S. Zorita, F.J. Peñas, Effect of water matrix on photocatalytic degradation and general kinetic modeling, Appl. Catal. B, 180 (2016) 330-335.

[59] N. Miranda-García, S. Suárez, B. Sánchez, J.M. Coronado, S. Malato, M.I. Maldonado, Photocatalytic degradation of emerging contaminants in municipal wastewater treatment plant effluents using immobilized $\mathrm{TiO}_{2}$ in a solar pilot plant, Appl. Catal. B, 103 (2011) 294-301.

[60] M. Bosio, S. Satyro, J.P. Bassin, E. Saggioro, M. Dezotti, Removal of pharmaceutically active compounds from synthetic and real aqueous mixtures and simultaneous disinfection by supported $\mathrm{TiO}_{2} / \mathrm{UV}-\mathrm{A}, \mathrm{H}_{2} \mathrm{O}_{2} / \mathrm{UV}-\mathrm{A}$, and $\mathrm{TiO}_{2} / \mathrm{H}_{2} \mathrm{O}_{2} / \mathrm{UV}$-A processes, Environ. Sci. Pollut. R., (2018).

[61] S. Kotzamanidi, Z. Frontistis, V. Binas, G. Kiriakidis, D. Mantzavinos, Solar photocatalytic degradation of propyl paraben in Al-doped $\mathrm{TiO}_{2}$ suspensions, Catal. Today, 313 (2018) 148-154.

[62] M. Sarro, N.P. Gule, E. Laurenti, R. Gamberini, M.C. Paganini, P.E. Mallon, P. Calza, ZnObased materials and enzymes hybrid systems as highly efficient catalysts for recalcitrant pollutants abatement, Chem. Eng. J., 334 (2018) 2530-2538.

[63] K. Sornalingam, A. McDonagh, J.L. Zhou, M.A.H. Johir, M.B. Ahmed, Photocatalysis of estrone in water and wastewater: Comparison between $\mathrm{Au}-\mathrm{TiO}_{2}$ nanocomposite and $\mathrm{TiO}_{2}$, and degradation by-products, Sci. Total Environ., 610-611 (2018) 521-530.

[64] H. Dimitroula, V.M. Daskalaki, Z. Frontistis, D.I. Kondarides, P. Panagiotopoulou, N.P. Xekoukoulotakis, D. Mantzavinos, Solar photocatalysis for the abatement of emerging microcontaminants in wastewater: Synthesis, characterization and testing of various $\mathrm{TiO}_{2}$ samples, Appl. Catal. B, 117-118 (2012) 283-291.

[65] E.M. Saggioro, A.S. Oliveira, T. Pavesi, M.J. Tototzintle, M.I. Maldonado, F.V. Correia, J.C. Moreira, Solar CPC pilot plant photocatalytic degradation of bisphenol A in waters and wastewaters using suspended and supported- $\mathrm{TiO}_{2}$. Influence of photogenerated species, Environ. Sci. Pollut. R., 21 (2014) 12112-12121.

[66] L. Rizzo, S. Meric, M. Guida, D. Kassinos, V. Belgiorno, Heterogenous photocatalytic degradation kinetics and detoxification of an urban wastewater treatment plant effluent contaminated with pharmaceuticals, Water Res., 43 (2009) 4070-4078.

[67] Z. Frontistis, V.M. Daskalaki, E. Hapeshi, C. Drosou, D. Fatta-Kassinos, N.P. Xekoukoulotakis, D. Mantzavinos, Photocatalytic $\left(\mathrm{UV}-\mathrm{A} / \mathrm{TiO}_{2}\right)$ degradation of $17 \alpha-$ ethynylestradiol in environmental matrices: Experimental studies and artificial neural network modeling, J. Photochem. Photobiol. A: Chem., 240 (2012) 33-41. 
[68] Z. Frontistis, C. Drosou, K. Tyrovola, D. Mantzavinos, D. Fatta-Kassinos, D. Venieri, N.P. Xekoukoulotakis, Experimental and Modeling Studies of the Degradation of Estrogen Hormones in Aqueous $\mathrm{TiO}_{2}$ Suspensions under Simulated Solar Radiation, Ind. Eng. Chem. Res., 51 (2012) 16552-16563.

[69] Z. Frontistis, D. Fatta-Kassinos, D. Mantzavinos, N.P. Xekoukoulotakis, Photocatalytic degradation of $17 \alpha$-ethynylestradiol in environmental samples by $\mathrm{ZnO}$ under simulated solar radiation, J. Chem. Technol. Biotechnol., 87 (2012) 1051-1058.

[70] N. Jallouli, L.M. Pastrana-Martínez, A.R. Ribeiro, N.F.F. Moreira, J.L. Faria, O. Hentati, A.M.T. Silva, M. Ksibi, Heterogeneous photocatalytic degradation of ibuprofen in ultrapure water, municipal and pharmaceutical industry wastewaters using a $\mathrm{TiO}_{2} / \mathrm{UV}-\mathrm{LED}$ system, Chem. Eng. J., 334 (2018) 976-984.

[71] G.H. Safari, M. Hoseini, M. Seyedsalehi, H. Kamani, J. Jaafari, A.H. Mahvi, Photocatalytic degradation of tetracycline using nanosized titanium dioxide in aqueous solution, Int. J. Environ. Sci. Technol. (Tehran), 12 (2014) 603-616.

[72] G. Laera, B. Jin, H. Zhu, A. Lopez, Photocatalytic activity of $\mathrm{TiO}_{2}$ nanofibers in simulated and real municipal effluents, Catal. Today, 161 (2011) 147-152.

[73] M. Jiménez, M. Ignacio Maldonado, E.M. Rodríguez, A. Hernández-Ramírez, E. Saggioro, I. Carra, J.A. Sánchez Pérez, Supported $\mathrm{TiO}_{2}$ solar photocatalysis at semi-pilot scale: degradation of pesticides found in citrus processing industry wastewater, reactivity and influence of photogenerated species, J. Chem. Technol. Biotechnol., 90 (2015) 149-157.

[74] R.P. Cavalcante, R.F. Dantas, H. Wender, B. Bayarri, O. González, J. Giménez, S. Esplugas, A. Machulek, Photocatalytic treatment of metoprolol with B-doped $\mathrm{TiO}_{2}$ : Effect of water matrix, toxicological evaluation and identification of intermediates, Appl. Catal. B, 176-177 (2015) 173182.

[75] M.N. Chong, B. Jin, G. Laera, C.P. Saint, Evaluating the photodegradation of Carbamazepine in a sequential batch photoreactor system: Impacts of effluent organic matter and inorganic ions, Chem. Eng. J., 174 (2011) 595-602.

[76] E. Hapeshi, A. Achilleos, M.I. Vasquez, C. Michael, N.P. Xekoukoulotakis, D. Mantzavinos, D. Kassinos, Drugs degrading photocatalytically: Kinetics and mechanisms of ofloxacin and atenolol removal on titania suspensions, Water Res., 44 (2010) 1737-1746.

[77] E. Marquez Brazon, C. Piccirillo, I.S. Moreira, P.M. Castro, Photodegradation of pharmaceutical persistent pollutants using hydroxyapatite-based materials, J. Environ. Manage., 182 (2016) 486-495.

[78] N.P. Xekoukoulotakis, C. Drosou, C. Brebou, E. Chatzisymeon, E. Hapeshi, D. FattaKassinos, D. Mantzavinos, Kinetics of UV-A/ $/ \mathrm{TiO}_{2}$ photocatalytic degradation and mineralization of the antibiotic sulfamethoxazole in aqueous matrices, Catal. Today, 161 (2011) 163-168.

[79] J. Ziemianska, E. Adamek, A. Sobczak, I. Lipska, A. Makowski, W. BARAN, The study of photocatalytic degradation of sulfonamides applied to municipal wastewater, Physicochem. Probl. Mi., 45 (2010) 127-140. 
[80] H. Gulyas, M.K. Ogun, W. Meyer, M. Reich, R. Otterpohl, Inadequacy of carbamazepinespiked model wastewaters for testing photocatalysis efficiency, Sci. Total Environ., 542 (2016) 612-619.

[81] Y. He, N.B. Sutton, H.H.H. Rijnaarts, A.A.M. Langenhoff, Degradation of pharmaceuticals in wastewater using immobilized $\mathrm{TiO}_{2}$ photocatalysis under simulated solar irradiation, Appl. Catal. B, 182 (2016) 132-141.

[82] S. Teixeira, R. Gurke, H. Eckert, K. Kühn, J. Fauler, G. Cuniberti, Photocatalytic degradation of pharmaceuticals present in conventional treated wastewater by nanoparticle suspensions, $\mathrm{J}$. Environ. Chem. Eng., 4 (2016) 287-292.

[83] D. Darowna, S. Grondzewska, A.W. Morawski, S. Mozia, Removal of non-steroidal antiinflammatory drugs from primary and secondary effluents in a photocatalytic membrane reactor, J. Chem. Technol. Biotechnol., 89 (2014) 1265-1273.

[84] R. Matta, S. Tlili, S. Chiron, S. Barbati, Removal of carbamazepine from urban wastewater by sulfate radical oxidation, Environ. Chem. Lett., 9 (2010) 347-353.

[85] G. Plantard, A. Azais, J. Mendret, S. Brosillon, V. Goetz, Coupling of photocatalytic and separation processes as a contribution to mineralization of wastewater, Chemical Engineering and Processing - Process Intensification, 134 (2018) 115-123.

[86] E. Grilla, V. Matthaiou, Z. Frontistis, I. Oller, I. Polo, S. Malato, D. Mantzavinos, Degradation of antibiotic trimethoprim by the combined action of sunlight, $\mathrm{TiO}_{2}$ and persulfate: A pilot plant study, Catal. Today, (2018).

[87] F.J. Benitez, J.L. Acero, F.J. Real, G. Roldan, Ozonation of pharmaceutical compounds: Rate constants and elimination in various water matrices, Chemosphere, 77 (2009) 53-59.

[88] I. Carra, J.A. Sánchez Pérez, S. Malato, O. Autin, B. Jefferson, P. Jarvis, Performance of different advanced oxidation processes for tertiary wastewater treatment to remove the pesticide acetamiprid, J. Chem. Technol. Biotechnol., 91 (2014) 72-81.

[89] R. Qu, M. Feng, X. Wang, Q. Huang, J. Lu, L. Wang, Z. Wang, Rapid Removal of Tetrabromobisphenol A by Ozonation in Water: Oxidation Products, Reaction Pathways and Toxicity Assessment, PLoS One, 10 (2015) e0139580.

[90] M. Feng, L. Yan, X. Zhang, P. Sun, S. Yang, L. Wang, Z. Wang, Fast removal of the antibiotic flumequine from aqueous solution by ozonation: Influencing factors, reaction pathways, and toxicity evaluation, Sci. Total Environ., 541 (2016) 167-175.

[91] F.J. Benitez, J.L. Acero, F.J. Real, G. Roldan, F. Casas, Comparison of different chemical oxidation treatments for the removal of selected pharmaceuticals in water matrices, Chem. Eng. J., 168 (2011) 1149-1156.

[92] A. Aguinaco, F.J. Beltrán, J.F. García-Araya, A. Oropesa, Photocatalytic ozonation to remove the pharmaceutical diclofenac from water: Influence of variables, Chem. Eng. J., 189-190 (2012) 275-282.

[93] M.G. Antoniou, G. Hey, S. Rodriguez Vega, A. Spiliotopoulou, J. Fick, M. Tysklind, J. la Cour Jansen, H.R. Andersen, Required ozone doses for removing pharmaceuticals from wastewater effluents, Sci. Total Environ., 456-457 (2013) 42-49. 
[94] J.B. Carbajo, A.L. Petre, R. Rosal, S. Herrera, P. Leton, E. Garcia-Calvo, A.R. FernandezAlba, J.A. Perdigon-Melon, Continuous ozonation treatment of ofloxacin: transformation products, water matrix effect and aquatic toxicity, J. Hazard. Mater., 292 (2015) 34-43.

[95] J.B. Carbajo, A.L. Petre, R. Rosal, A. Berná, P. Letón, E. García-Calvo, J.A. PerdigónMelón, Ozonation as pre-treatment of activated sludge process of a wastewater containing benzalkonium chloride and NiO nanoparticles, Chem. Eng. J., 283 (2016) 740-749.

[96] P. Westlund, S. Isazadeh, A. Therrien, V. Yargeau, Endocrine Activities of Pesticides During Ozonation of Waters, Bull. Environ. Contam. Toxicol., 100 (2018) 112-119.

[97] A.L. Petre, J.B. Carbajo, R. Rosal, E. Garcia-Calvo, J.A. Perdigón-Melón, CuO/SBA-15 catalyst for the catalytic ozonation of mesoxalic and oxalic acids. Water matrix effects, Chem. Eng. J., 225 (2013) 164-173.

[98] D.S. Gomes, L.M. Gando-Ferreira, R.M. Quinta-Ferreira, R.C. Martins, Removal of sulfamethoxazole and diclofenac from water: strategies involving $\mathrm{O}_{3}$ and $\mathrm{H}_{2} \mathrm{O}_{2}$, Environ. Technol., (2017) 1-12.

[99] R. Rosal, A. Rodriguez, J.A. Perdigon-Melon, M. Mezcua, M.D. Hernando, P. Leton, E. Garcia-Calvo, A. Aguera, A.R. Fernandez-Alba, Removal of pharmaceuticals and kinetics of mineralization by $\mathrm{O}_{3} / \mathrm{H}_{2} \mathrm{O}_{2}$ in a biotreated municipal wastewater, Water Res., 42 (2008) 37193728.

[100] P. Pocostales, P. Álvarez, F.J. Beltrán, Catalytic ozonation promoted by alumina-based catalysts for the removal of some pharmaceutical compounds from water, Chem. Eng. J., 168 (2011) 1289-1295.

[101] N.F.F. Moreira, C.A. Orge, A.R. Ribeiro, J.L. Faria, O.C. Nunes, M.F.R. Pereira, A.M.T. Silva, Fast mineralization and detoxification of amoxicillin and diclofenac by photocatalytic ozonation and application to an urban wastewater, Water Res., 87 (2015) 87-96.

[102] A.L. Petre, J.B. Carbajo, R. Rosal, E. García-Calvo, P. Letón, J.A. Perdigón-Melón, Influence of water matrix on copper-catalysed continuous ozonation and related ecotoxicity, Appl. Catal. B, 163 (2015) 233-240.

[103] Á. Encinas, F.J. Rivas, F.J. Beltrán, A. Oropesa, Combination of Black-Light Photocatalysis and Ozonation for Emerging Contaminants Degradation in Secondary Effluents, Chem. Eng. Technol., 36 (2013) 492-499.

[104] F.J. Real, F.J. Benitez, J.L. Acero, G. Roldan, Combined chemical oxidation and membrane filtration techniques applied to the removal of some selected pharmaceuticals from water systems, J. Environ. Sci. Health., Part A, 47 (2012) 522-533.

[105] X. Yuan, S. Lacorte, J. Cristale, R.F. Dantas, C. Sans, S. Esplugas, Z. Qiang, Removal of organophosphate esters from municipal secondary effluent by ozone and $\mathrm{UV} / \mathrm{H}_{2} \mathrm{O}_{2}$ treatments, Sep. Purif. Technol., 156 (2015) 1028-1034.

[106] S. Sarkar, S. Ali, L. Rehmann, G. Nakhla, M.B. Ray, Degradation of estrone in water and wastewater by various advanced oxidation processes, J. Hazard. Mater., 278 (2014) 16-24.

[107] N.H.S. Javadi, M. Baghdadi, N. Mehrdadi, M. Mortazavi, Removal of benzotriazole from secondary municipal wastewater effluent by catalytic ozonation in the presence of magnetic alumina nanocomposite, J. Environ. Chem. Eng., 6 (2018) 6421-6430. 
[108] A. Mirzaei, Z. Chen, F. Haghighat, L. Yerushalmi, Removal of pharmaceuticals from water by homo/heterogonous Fenton-type processes - A review, Chemosphere, 174 (2017) 665-688.

[109] A.D. Bokare, W. Choi, Review of iron-free Fenton-like systems for activating $\mathrm{H}_{2} \mathrm{O}_{2}$ in advanced oxidation processes, J. Hazard. Mater., 275 (2014) 121-135.

[110] F. Duarte, F.J. Maldonado-Hódar, L.M. Madeira, Influence of the characteristics of carbon materials on their behaviour as heterogeneous Fenton catalysts for the elimination of the azo dye Orange II from aqueous solutions, Appl. Catal. B, 103 (2011) 109-115.

[111] P.V. Nidheesh, R. Gandhimathi, Trends in electro-Fenton process for water and wastewater treatment: An overview, Desalination, 299 (2012) 1-15.

[112] R. Andreozzi, V. Caprio, A. Insola, R. Marotta, Advanced oxidation processes (AOP) for water purification and recovery, Catal. Today, 53 (1999) 51-59.

[113] T. Mackul'ak, J. Prousek, L.u. Švorc, Degradation of atrazine by Fenton and modified Fenton reactions, Monatsh. Chem., 142 (2011) 561-567.

[114] D. Hermosilla, M. Cortijo, C.P. Huang, Optimizing the treatment of landfill leachate by conventional Fenton and photo-Fenton processes, Sci. Total Environ., 407 (2009) 3473-3481.

[115] N. De la Cruz, J. Gimenez, S. Esplugas, D. Grandjean, L.F. de Alencastro, C. Pulgarin, Degradation of 32 emergent contaminants by UV and neutral photo-fenton in domestic wastewater effluent previously treated by activated sludge, Water Res., 46 (2012) 1947-1957.

[116] P.R. Gogate, A.B. Pandit, A review of imperative technologies for wastewater treatment II: hybrid methods, Adv. Environ. Res., 8 (2004) 553-597.

[117] S. Papoutsakis, S. Miralles-Cuevas, I. Oller, J.L. Garcia Sanchez, C. Pulgarin, S. Malato, Microcontaminant degradation in municipal wastewater treatment plant secondary effluent by EDDS assisted photo-Fenton at near-neutral pH: An experimental design approach, Catal. Today, 252 (2015) 61-69.

[118] M. Umar, H.A. Aziz, M.S. Yusoff, Trends in the use of Fenton, electro-Fenton and photoFenton for the treatment of landfill leachate, Waste Manage., 30 (2010) 2113-2121.

[119] I. Michael, E. Hapeshi, C. Michael, A.R. Varela, S. Kyriakou, C.M. Manaia, D. FattaKassinos, Solar photo-Fenton process on the abatement of antibiotics at a pilot scale: Degradation kinetics, ecotoxicity and phytotoxicity assessment and removal of antibiotic resistant enterococci, Water Res., 46 (2012) 5621-5634.

[120] N. Klamerth, N. Miranda, S. Malato, A. Agüera, A.R. Fernández-Alba, M.I. Maldonado, J.M. Coronado, Degradation of emerging contaminants at low concentrations in MWTPs effluents with mild solar photo-Fenton and $\mathrm{TiO}_{2}$, Catal. Today, 144 (2009) 124-130.

[121] L.O. Conte, A.V. Schenone, B.N. Giménez, O.M. Alfano, Photo-Fenton degradation of a herbicide $(2,4-\mathrm{D})$ in groundwater for conditions of natural $\mathrm{pH}$ and presence of inorganic anions, J. Hazard. Mater., (2018).

[122] L. Clarizia, D. Russo, I. Di Somma, R. Marotta, R. Andreozzi, Homogeneous photo-Fenton processes at near neutral pH: A review, Appl. Catal. B, 209 (2017) 358-371. 
[123] T. Papadam, N.P. Xekoukoulotakis, I. Poulios, D. Mantzavinos, Photocatalytic transformation of acid orange 20 and $\mathrm{Cr}(\mathrm{VI})$ in aqueous $\mathrm{TiO}_{2}$ suspensions, J. Photochem. Photobiol. A: Chem., 186 (2007) 308-315.

[124] G. Li Puma, A. Bono, D. Krishnaiah, J.G. Collin, Preparation of titanium dioxide photocatalyst loaded onto activated carbon support using chemical vapor deposition: A review paper, J. Hazard. Mater., 157 (2008) 209-219.

[125] I. Grčić, G. Li Puma, Photocatalytic Degradation of Water Contaminants in Multiple Photoreactors and Evaluation of Reaction Kinetic Constants Independent of Photon Absorption, Irradiance, Reactor Geometry, and Hydrodynamics, Environ. Sci. Technol., 47 (2013) 1370213711.

[126] J. Fenoll, P. Sabater, G. Navarro, G. Pérez-Lucas, S. Navarro, Photocatalytic transformation of sixteen substituted phenylurea herbicides in aqueous semiconductor suspensions: Intermediates and degradation pathways, J. Hazard. Mater., 244-245 (2013) 370-379.

[127] L. Prieto-Rodríguez, S. Miralles-Cuevas, I. Oller, A. Aguera, G. Li Puma, S. Malato, Treatment of emerging contaminants in wastewater treatment plants (WWTP) effluents by solar photocatalysis using low $\mathrm{TiO}_{2}$ concentrations, J. Hazard. Mater., 211-212 (2012) 131-137.

[128] M.J. Lima, A.M.T. Silva, C.G. Silva, J.L. Faria, Graphitic carbon nitride modified by thermal, chemical and mechanical processes as metal-free photocatalyst for the selective synthesis of benzaldehyde from benzyl alcohol, J. Catal., 353 (2017) 44-53.

[129] S. Sakthivel, M.V. Shankar, M. Palanichamy, B. Arabindoo, D.W. Bahnemann, V. Murugesan, Enhancement of photocatalytic activity by metal deposition: characterisation and photonic efficiency of $\mathrm{Pt}, \mathrm{Au}$ and $\mathrm{Pd}$ deposited on $\mathrm{TiO}_{2}$ catalyst, Water Res., 38 (2004) 30013008 .

[130] S.B. Rawal, S. Bera, D. Lee, D.-J. Jang, W.I. Lee, Design of visible-light photocatalysts by coupling of narrow bandgap semiconductors and $\mathrm{TiO}_{2}$ : effect of their relative energy band positions on the photocatalytic efficiency, Catalysis Science \& Technology, 3 (2013) 1822-1830.

[131] A.M.T. Silva, C.G. Silva, G. Dražić, J.L. Faria, Ce-doped TiO2 for photocatalytic degradation of chlorophenol, Catal. Today, 144 (2009) 13-18.

[132] M. Pedrosa, L.M. Pastrana-Martínez, M.F.R. Pereira, J.L. Faria, J.L. Figueiredo, A.M.T. Silva, N/S-doped graphene derivatives and $\mathrm{TiO}_{2}$ for catalytic ozonation and photocatalysis of water pollutants, Chem. Eng. J., 348 (2018) 888-897.

[133] N.F.F. Moreira, C. Narciso-da-Rocha, M.I. Polo-López, L.M. Pastrana-Martínez, J.L. Faria, C.M. Manaia, P. Fernández-Ibáñez, O.C. Nunes, A.M.T. Silva, Solar treatment $\left(\mathrm{H}_{2} \mathrm{O}_{2}, \mathrm{TiO}_{2}-\mathrm{P} 25\right.$ and $\mathrm{GO}^{-\mathrm{TiO}_{2}}$ photocatalysis, photo-Fenton) of organic micropollutants, human pathogen indicators, antibiotic resistant bacteria and related genes in urban wastewater, Water Res., 135 (2018) 195-206.

[134] S. Morales-Torres, A.M.T. Silva, F.J. Maldonado-Hódar, B.F. Machado, A.F. PérezCadenas, J.L. Faria, J.L. Figueiredo, F. Carrasco-Marín, Pt-catalysts supported on activated carbons for catalytic wet air oxidation of aniline: Activity and stability, Appl. Catal. B, 105 (2011) 86-94. 
[135] S. Morales-Torres, A.M.T. Silva, A.F. Pérez-Cadenas, J.L. Faria, F.J. Maldonado-Hódar, J.L. Figueiredo, F. Carrasco-Marín, Wet air oxidation of trinitrophenol with activated carbon catalysts: Effect of textural properties on the mechanism of degradation, Appl. Catal. B, 100 (2010) 310-317.

[136] M.E. Metheniti, Z. Frontistis, R.S. Ribeiro, A.M.T. Silva, J.L. Faria, H.T. Gomes, D. Mantzavinos, Degradation of propyl paraben by activated persulfate using iron-containing magnetic carbon xerogels: investigation of water matrix and process synergy effects, Environ. Sci. Pollut. R., (2017) 1-10.

[137] D.F.M. Santos, O.S.G.P. Soares, A.M.T. Silva, J.L. Figueiredo, M.F.R. Pereira, Catalytic wet oxidation of organic compounds over $\mathrm{N}$-doped carbon nanotubes in batch and continuous operation, Appl. Catal. B, 199 (2016) 361-371.

[138] R.S. Ribeiro, A.M.T. Silva, J.L. Figueiredo, J.L. Faria, H.T. Gomes, Catalytic wet peroxide oxidation: A route towards the application of hybrid magnetic carbon nanocomposites for the degradation of organic pollutants. A review, Appl. Catal. B, 187 (2016) 428-460.

[139] R.S. Ribeiro, R.O. Rodrigues, A.M.T. Silva, P.B. Tavares, A.M.C. Carvalho, J.L. Figueiredo, J.L. Faria, H.T. Gomes, Hybrid magnetic graphitic nanocomposites towards catalytic wet peroxide oxidation of the liquid effluent from a mechanical biological treatment plant for municipal solid waste, Appl. Catal. B, 219 (2017) 645-657.

[140] L. Svoboda, P. Praus, M.J. Lima, M.J. Sampaio, D. Matýsek, M. Ritz, R. Dvorský, J.L. Faria, C.G. Silva, Graphitic carbon nitride nanosheets as highly efficient photocatalysts for phenol degradation under high-power visible LED irradiation, Mater. Res. Bull., 100 (2018) 322-332.

[141] A.L. Linsebigler, G. Lu, J.T. Yates, Photocatalysis on $\mathrm{TiO}_{2}$ Surfaces: Principles, Mechanisms, and Selected Results, Chem. Rev., 95 (1995) 735-758.

[142] S. Morales-Torres, L.M. Pastrana-Martínez, J.L. Figueiredo, J.L. Faria, A.M.T. Silva, Design of graphene-based $\mathrm{TiO}_{2}$ photocatalysts—a review, Environ. Sci. Pollut. R., 19 (2012) 3676-3687.

[143] C.S. Uyguner-Demirel, N.C. Birben, M. Bekbolet, Elucidation of background organic matter matrix effect on photocatalytic treatment of contaminants using $\mathrm{TiO}_{2}$ : A review, Catal. Today, 284 (2017) 202-214.

[144] T.E. Doll, F.H. Frimmel, Photocatalytic degradation of carbamazepine, clofibric acid and iomeprol with P25 and Hombikat UV100 in the presence of natural organic matter (NOM) and other organic water constituents, Water Res., 39 (2005) 403-411.

[145] G. Márquez, E.M. Rodríguez, M.I. Maldonado, P.M. Álvarez, Integration of ozone and solar $\mathrm{TiO}_{2}$-photocatalytic oxidation for the degradation of selected pharmaceutical compounds in water and wastewater, Sep. Purif. Technol., 136 (2014) 18-26.

[146] D. Friedmann, C. Mendive, D. Bahnemann, $\mathrm{TiO}_{2}$ for water treatment: Parameters affecting the kinetics and mechanisms of photocatalysis, Appl. Catal. B, 99 (2010) 398-406.

[147] G. Li, L. Lv, H. Fan, J. Ma, Y. Li, Y. Wan, X.S. Zhao, Effect of the agglomeration of $\mathrm{TiO}_{2}$ nanoparticles on their photocatalytic performance in the aqueous phase, J. Colloid Interface Sci., 348 (2010) 342-347. 
[148] R.A. French, A.R. Jacobson, B. Kim, S.L. Isley, R.L. Penn, P.C. Baveye, Influence of Ionic Strength, pH, and Cation Valence on Aggregation Kinetics of Titanium Dioxide Nanoparticles, Environ. Sci. Technol., 43 (2009) 1354-1359.

[149] C. Wang, L. Zhu, M. Wei, P. Chen, G. Shan, Photolytic reaction mechanism and impacts of coexisting substances on photodegradation of bisphenol A by $\mathrm{Bi}_{2} \mathrm{WO}_{6}$ in water, Water Res., 46 (2012) 845-853.

[150] M. Bourgin, B. Beck, M. Boehler, E. Borowska, J. Fleiner, E. Salhi, R. Teichler, U. von Gunten, H. Siegrist, C.S. McArdell, Evaluation of a full-scale wastewater treatment plant upgraded with ozonation and biological post-treatments: Abatement of micropollutants, formation of transformation products and oxidation by-products, Water Res., 129 (2018) 486498.

[151] W.T. Li, M. Majewsky, G. Abbt-Braun, H. Horn, J. Jin, Q. Li, Q. Zhou, A.M. Li, Application of portable online LED UV fluorescence sensor to predict the degradation of dissolved organic matter and trace organic contaminants during ozonation, Water Res., 101 (2016) 262-271.

[152] Y. Lee, D. Gerrity, M. Lee, A.E. Bogeat, E. Salhi, S. Gamage, R.A. Trenholm, E.C. Wert, S.A. Snyder, U. von Gunten, Prediction of Micropollutant Elimination during Ozonation of Municipal Wastewater Effluents: Use of Kinetic and Water Specific Information, Environ. Sci. Technol., 47 (2013) 5872-5881.

[153] U. von Gunten, Ozonation of drinking water: Part I. Oxidation kinetics and product formation, Water Res., 37 (2003) 1443-1467.

[154] M.S. Lucas, J.A. Peres, B.Y. Lan, G. Li Puma, Ozonation kinetics of winery wastewater in a pilot-scale bubble column reactor, Water Res., 43 (2009) 1523-1532.

[155] J. Santiago-Morales, M.J. Gomez, S. Herrera-Lopez, A.R. Fernandez-Alba, E. GarciaCalvo, R. Rosal, Energy efficiency for the removal of non-polar pollutants during ultraviolet irradiation, visible light photocatalysis and ozonation of a wastewater effluent, Water Res., 47 (2013) 5546-5556.

[156] M.-O. Buffle, J. Schumacher, S. Meylan, M. Jekel, U. von Gunten, Ozonation and Advanced Oxidation of Wastewater: Effect of $\mathrm{O}_{3}$ Dose, $\mathrm{pH}$, DOM and HO-- Scavengers on Ozone Decomposition and HO• Generation, Ozone Sci. Eng., 28 (2006) 247-259.

[157] M. Saquib, C. Vinckier, B. Van der Bruggen, The effect of UF on the efficiency of $\mathrm{O}_{3} / \mathrm{H}_{2} \mathrm{O}_{2}$ for the removal of organics from surface water, Desalination, 260 (2010) 39-42.

[158] Y. Liu, J. Jiang, J. Ma, Y. Yang, C. Luo, X. Huangfu, Z. Guo, Role of the propagation reactions on the hydroxyl radical formation in ozonation and peroxone (ozone/hydrogen peroxide) processes, Water Res., 68 (2015) 750-758.

[159] E.L. Yong, Y.-P. Lin, Kinetics of Natural Organic Matter as the Initiator, Promoter, and Inhibitor, and Their Influences on the Removal of Ibuprofen in Ozonation, Ozone Sci. Eng., 35 (2013) 472-481 .

[160] H.-F. Miao, M. Cao, D.-Y. Xu, H.-Y. Ren, M.-X. Zhao, Z.-X. Huang, W.-Q. Ruan, Degradation of phenazone in aqueous solution with ozone: Influencing factors and degradation pathways, Chemosphere, 119 (2015) 326-333. 
[161] J. Margot, C. Kienle, A. Magnet, M. Weil, L. Rossi, L.F. de Alencastro, C. Abegglen, D. Thonney, N. Chèvre, M. Schärer, D.A. Barry, Treatment of micropollutants in municipal wastewater: Ozone or powdered activated carbon?, Sci. Total Environ., 461-462 (2013) 480-498.

[162] N. Takeuchi, H. Mizoguchi, Study of optimal parameters of the $\mathrm{H}_{2} \mathrm{O}_{2} / \mathrm{O}_{3}$ method for the decomposition of acetic acid, Chem. Eng. J., 313 (2017) 309-316.

[163] T.E. Agustina, H.M. Ang, V.K. Vareek, A review of synergistic effect of photocatalysis and ozonation on wastewater treatment, J Photochem. Photobiol. C: Photochem. Rev., 6 (2005) 264-273.

[164] F. Thevenet, O. Guaïtella, J.M. Herrmann, A. Rousseau, C. Guillard, Photocatalytic degradation of acetylene over various titanium dioxide-based photocatalysts, Appl. Catal. B, 61 (2005) 58-68.

[165] J. Xiao, Y. Xie, H. Cao, Organic pollutants removal in wastewater by heterogeneous photocatalytic ozonation, Chemosphere, 121 (2015) 1-17.

[166] L. Sánchez, J. Peral, X. Domènech, Aniline degradation by combined photocatalysis and ozonation, Appl. Catal. B, 19 (1998) 59-65.

[167] P. Kopf, E. Gilbert, S.H. Eberle, $\mathrm{TiO}_{2}$ photocatalytic oxidation of monochloroacetic acid and pyridine: influence of ozone, J. Photochem. Photobiol. A: Chem., 136 (2000) 163-168.

[168] L. Li, W. Zhu, L. Chen, P. Zhang, Z. Chen, Photocatalytic ozonation of dibutyl phthalate over $\mathrm{TiO}_{2}$ film, J. Photochem. Photobiol. A: Chem., 175 (2005) 172-177.

[169] D.S. Bhatkhande, V.G. Pangarkar, A.A.C.M. Beenackers, Photocatalytic degradation for environmental applications - a review, J. Chem. Technol. Biotechnol., 77 (2002) 102-116.

[170] T.S. Müller, Z. Sun, G. Kumar, K. Itoh, M. Murabayashi, The combination of photocatalysis and ozonolysis as a new approach for cleaning 2,4-dichlorophenoxyaceticacid polluted water, Chemosphere, 36 (1998) 2043-2055.

[171] G.V. Buxton, C.L. Greenstock, W.P. Helman, A.B. Ross, Critical Review of rate constants for reactions of hydrated electrons, hydrogen atoms and hydroxyl radicals $(\cdot \mathrm{OH} / \cdot \mathrm{O}-$ in Aqueous Solution, J. Phys. Chem. Ref. Data, 17 (1988) 513-886.

[172] W.H. Koppenol, J. Butler, J.W.v. Leeuwen, THE HABER-WEISS CYCLE, Photochem. Photobiol., 28 (1978) 655-658.

[173] Y. Liu, X. He, X. Duan, Y. Fu, D. Fatta-Kassinos, D.D. Dionysiou, Significant role of UV and carbonate radical on the degradation of oxytetracycline in UV-AOPs: Kinetics and mechanism, Water Res., 95 (2016) 195-204.

[174] C. Walling, A. Goosen, Mechanism of the ferric ion catalyzed decomposition of hydrogen peroxide. Effect of organic substrates, J. Am. Chem. Soc., 95 (1973) 2987-2991.

[175] B.H.J. Bielski, D.E. Cabelli, R.L. Arudi, A.B. Ross, Reactivity of $\mathrm{HO}_{2} / \mathrm{O}_{-2}$ Radicals in Aqueous Solution, J. Phys. Chem. Ref. Data, 14 (1985) 1041-1100.

[176] N.M. Ram, R.F. Christman, K.P. Cantor, Significance and treatment of volatile organic compounds in water supplies, in, Chelsea, MI (US); Lewis Publishers, Inc., 1990, pp. 339. 


\section{Supplementary Information}

Impact of water matrix on the removal of micropollutants by advanced oxidation technologies

Ana R. Ribeiro ${ }^{1, *}$, Nuno F.F. Moreira ${ }^{1}$, Gianluca Li Puma ${ }^{2, *}$, Adrián M.T. Silva ${ }^{1}$

${ }^{1}$ Laboratory of Separation and Reaction Engineering - Laboratory of Catalysis and Materials (LSRE-

LCM), Faculdade de Engenharia, Universidade do Porto, Rua Dr. Roberto Frias s/n, 4200-465 Porto, Portugal

${ }^{2}$ Environmental Nanocatalysis \& Photoreaction Engineering, Department of Chemical Engineering, Loughborough University, Loughborough, United Kingdom

*Corresponding authors: ritalado@fe.up.pt (A.R. Ribeiro), G.Lipuma@lboro.ac.uk (G. Li Puma) 
Table S1. Matrix effects occurring in studies dealing with photolysis and $\mathrm{UV} / \mathrm{H}_{2} \mathrm{O}_{2}$, published since 2005. Unless otherwise stated, the experimental conditions refer to the tested conditions for the evaluation of matrix effects.

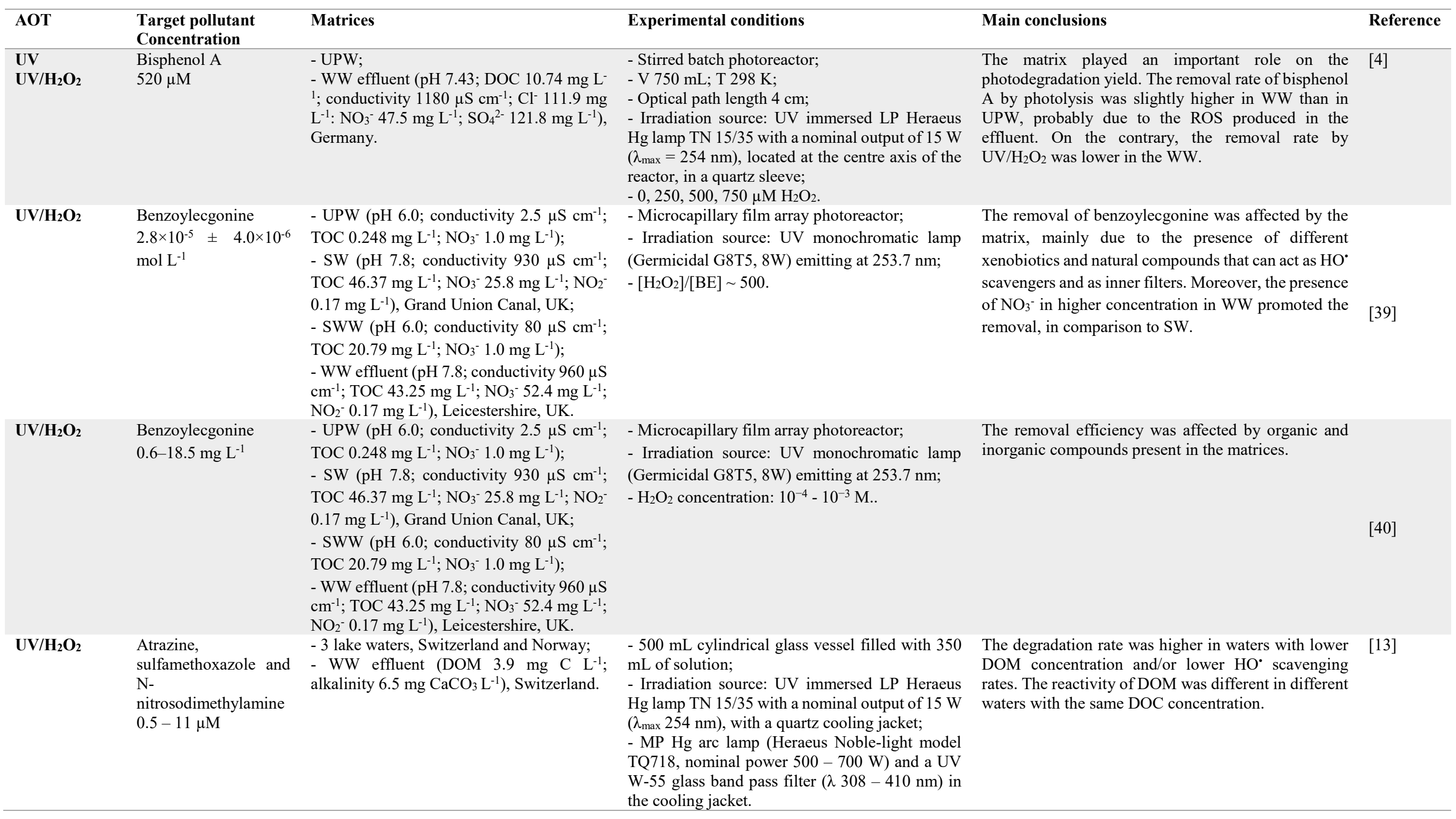


metoprolol,

benzotriazole,

mecoprop

ng L $\mathrm{L}^{-1}$ to $\mu \mathrm{g} \mathrm{L}^{-1}$ levels

UV

Hydrochlorothiazide

$1 \mu \mathrm{M}$

Azathioprine,

cyclophosphamide,

cytarabine,

doxorubicin,

methotrexate,

fluorouracil, flutamide

and mitotane

$100 \mu \mathrm{g} \mathrm{L}^{-1}$

$\begin{array}{ll}\mathbf{U V} & \mathrm{E} 1, \mathrm{E} 2, \mathrm{EE} 2\end{array}$

- WW effluents with different secondary treatment, namely activated sludge $(\mathrm{pH} 7.8$; TOC $37 \mathrm{mg} \mathrm{L}^{-1}$; COD $63 \mathrm{mg} \mathrm{L}^{-1}$; alkalinity $273 \mathrm{mg} \mathrm{CaCO} \mathrm{L}^{-1}$; Fe total $0.9 \mathrm{mg} \mathrm{L}^{-1}$; TSS $12 \mathrm{mg} \mathrm{L}^{-1}$ ); moving bed bioreactor ( $\mathrm{pH} 7.4$; TOC $20.2 \mathrm{mg} \mathrm{L} \mathrm{L}^{-1}$; COD $35 \mathrm{mg} \mathrm{L}^{-1}$ : alkalinity $85 \mathrm{mg} \mathrm{CaCO}_{3} \mathrm{~L}^{-1} ; \mathrm{Fe}_{\text {total }} 1.6 \mathrm{mg} \mathrm{L}^{-}$ 1; TSS $14 \mathrm{mg} \mathrm{L}^{-1}$ ) and coagulation flocculation $\left(\mathrm{pH} 7.9\right.$; TOC $57.2 \mathrm{mg} \mathrm{L}^{-1}$; COD $90 \mathrm{mg} \mathrm{L}^{-1}$; alkalinity $231 \mathrm{mg} \mathrm{\textrm {CaCO } _ { 3 }}$ $\mathrm{L}^{-1}$; $\mathrm{Fe}_{\text {total }} 1.9 \mathrm{mg} \mathrm{L}^{-1}$; TSS $30 \mathrm{mg} \mathrm{L}^{-1}$ ), Lausanne, Switzerland.

- UPW;

- SW from a public reservoir, Spain; - WW effluent (pH 8.0; TOC $23.3 \mathrm{mg} \mathrm{L}^{-1}$; alkalinity $250 \mathrm{mg} \mathrm{CaCO}_{3} \mathrm{~L}^{-1}$ ), Spain.

- DI (pH 6.0; turbidity <0.1 NTU; TOC 0.08 $\mathrm{mg} \mathrm{L}^{-1}$; Total alkalinity $<5.0 \mathrm{mg} \mathrm{L}^{-1} ; \mathrm{NO}_{3}{ }^{-}$ $<0.05 \mathrm{mg} \mathrm{L}{ }^{-1} ; \mathrm{SO}_{4}{ }^{2-}<0.05 \mathrm{mg} \mathrm{L}^{-1}, \mathrm{Cl}^{-}<5.0$ $\left.\mathrm{mg} \mathrm{L}^{-1}\right)$;

5- $\quad$ - Treated water from water treatment plant (pH 8.0; turbidity 0.2 NTU; TOC $0.8 \mathrm{mg} \mathrm{L}$ ${ }^{1}$; alkalinity $13.0 \mathrm{mg} \mathrm{L}^{-1} ; \mathrm{NO}_{3}^{-} 3.2 \mathrm{mg} \mathrm{L}^{-1}$; $\left.\mathrm{SO}_{4}^{2-} 21.6 \mathrm{mg} \mathrm{L}^{-1}, \mathrm{Cl}^{-1} 10.0 \mathrm{mg} \mathrm{L}^{-1}\right)$;

- WW effluent (pH 6.7; turbidity 5.3 NTU; TOC $10.6 \mathrm{mg} \mathrm{L}^{-1}$; alkalinity $54.9 \mathrm{mg} \mathrm{L}^{-1}$; $\mathrm{NO}_{3}{ }^{-6.3} \mathrm{mg} \mathrm{L}^{-1} ; \mathrm{SO}_{4}^{2-} 45.1 \mathrm{mg} \mathrm{L}^{-1}, \mathrm{Cl}^{-1} 145.5$ $\left.\mathrm{mg} \mathrm{L}^{-1}\right)$.

- DW;

- WW effluent ( $\mathrm{pH}$ 7.5-7.8; DOC 6.1-11 mg $\mathrm{L}^{-1}$; COD 18.5-21.7 $\mathrm{mg} \mathrm{L}^{-1}$; BOD $_{5} 3-5.8 \mathrm{mg}$ $\mathrm{L}^{-1}$; $\mathrm{SS} 2.0-4.7 \mathrm{mg} \mathrm{L}^{-1}: \mathrm{NH}_{4}^{+} 0.6-4.24 \mathrm{mg} \mathrm{L}^{-}$ ${ }_{1}^{1} ; \mathrm{NO}_{2}^{-}$0.09-0.54 mg L-1; $\mathrm{NO}_{3}^{-} 3.68-4.54$ $\mathrm{mg} \mathrm{L}^{-1}$ ), France.
- $300 \mathrm{~mL}$ double-wall, water-jacketed glass batch stirred reactors;

- UV-C irradiation source: $36 \mathrm{~W}$, low-pressure amalgam lamp $\left(\lambda_{\max } 254 \mathrm{~nm}\right)$;

$-\mathrm{H}_{2} \mathrm{O}_{2}: 25 \mathrm{mg} \mathrm{L}^{-1}$.

Regardless the type of secondary treatment, the degradation rates were higher when using $\mathrm{UV} / \mathrm{H}_{2} \mathrm{O}_{2}$ than UV-C. Both UV-based processes removed $80 \%$ of the selected MPs. Comparing matrices, the higher removal of both pollutants and TOC was achieved when using effluents resulting from moving bed bioreactor, following by activated sludge and coagulation flocculation. The $\mathrm{UV} / \mathrm{H}_{2} \mathrm{O}_{2}$ process led to a higher degradation rate of the MPs and TOC abatement.

- $500 \mathrm{~mL}$ cylindrical glass vessel filled with 350 $\mathrm{mL}$ of solution;

- Irradiation source: UV immersed LP Heraeus Hg lamp TN 15/35 with a nominal output of $15 \mathrm{~W}$ $\left(\lambda_{\max } 254 \mathrm{~nm}\right)$, located at the centre axis of the reactor, in a quartz sleeve;

- T $20^{\circ} \mathrm{C}$.

- Cylindrical photoreactor (1 L)

- Irradiation source: $5 \mathrm{~W}$ Philips UV lamp $\left(\lambda=\right.$ the target pollutants. $\mathrm{NO}_{3}^{-}\left(0.5\right.$ to $\left.5 \mathrm{mg} \mathrm{L}^{-1}\right)$ promoted $254 \mathrm{~nm})$

Addition of $\mathrm{HA}, \mathrm{HCO}_{3}{ }^{-}, \mathrm{NO}_{3}{ }^{-}, \mathrm{Cl}^{-}$, and $\mathrm{SO}_{4}{ }^{2-}$.

their photo did not affect it. The performance of the UV treatment was not reduced when applied to treated water since the TOC content of this matrix was very low. However, the degradation efficiency decreased in the WW effluent, with a much higher TOC content $(10.6$ $\mathrm{mg} \mathrm{L}^{-1}$ ). Furthermore, the addition of $\mathrm{S}_{2} \mathrm{O}_{8}{ }^{2-}$ and $\mathrm{H}_{2} \mathrm{O}_{2}$ increased the degradation efficiency.

- Commercial UVC reactor (COMAP WT) and a

$55 \mathrm{~W}$ LP lamp $\left(\lambda_{\max } 254 \mathrm{~nm}\right)$

UV photolysis was more efficient to degrade E1 than E2 and EE2 in both matrices, being the degradation Reactor: $81.5 \mathrm{~cm}$ long, $5.4 \mathrm{~cm}$ diameter, $1 \mathrm{~cm}$ rate constants in the same order of magnitude, distance between the lamp sleeve and the inner regardless the matrix. This low impact of the matrix on side of the chamber;

- V $1.12 \mathrm{~L} ; \mathrm{T} 20^{\circ} \mathrm{C}$;

$-\mathrm{H}_{2} \mathrm{O}_{2}: 10,40$ and $90 \mathrm{mg} \mathrm{L}^{-1}$

hotodegradation led to a lower removal rate in the regardless the matrix. This low impact of the matrix on
degradation rates was attributed to: (i) ROS formed by the action of UV on organic components of the matrices, probably balancing the low transmittance of the WW; and (ii) $\mathrm{NO}_{3}{ }^{-}$content, known to act as $\mathrm{HO}^{-}$ precursor. $\mathrm{UV} / \mathrm{H}_{2} \mathrm{O}_{2}$ process highly increased the removals of all hormones, but it was significantly affected by the water matrix, with lower degradation rate constants obtained in treated WW. The NOM competing for UV irradiation, and scavengers competing for $\mathrm{HO}^{*}$ (e.g., humic substances, $\mathrm{Cl}^{-}$, $\mathrm{HCO}_{3}{ }^{-}, \mathrm{SO}_{4}{ }^{2-}$, and $\mathrm{NO}_{3}{ }^{-}$) were suggested as main factors impacting the removals. 
$\mathrm{L}^{-1} ; \mathrm{PO}_{4}^{3-}<0.044 \mathrm{mg} \mathrm{L}^{-1} ; \mathrm{SO}_{4}{ }^{2-} 7.0 \mathrm{mg} \mathrm{L}^{-}$ - UV Irradiation source: two 8 W LP lamps (254 $0.5 \mathrm{mg} \mathrm{L}^{-1}$

$\left.{ }^{1}\right)$, Northwest of Spain

- Effect of $\mathrm{NO}_{3}{ }^{-}$addition $\left(25 \mathrm{mg} \mathrm{L}^{-1}\right)$.

- WW effluent (pH 7.1; DOC $3.61 \mathrm{mg} \mathrm{L}^{-1}$;

TC $12.8 \mathrm{mg} \mathrm{L}^{-1} ; \mathrm{NO}_{3}^{-} 4.7 \mathrm{mg} \mathrm{L}^{-1} ; \mathrm{Cl}^{-} 23.1$ $\mathrm{mg} \mathrm{L}^{-1} ; \mathrm{PO}_{4}^{3-} 1.32 \mathrm{mg} \mathrm{L}^{-1} ; \mathrm{SO}^{2-} 30.4 \mathrm{mg} \mathrm{L}$

$\left.{ }^{1}\right)$.

Monensin,

salinomycin, narasin

- DI

$0.5 \mathrm{mg} \mathrm{L}^{-1}$

- WW effluent (pH 7.4; $\mathrm{Cl}^{-} 23.1 \mathrm{mg} \mathrm{L}^{-1}$

DOC $0.435 \mathrm{mg} \mathrm{L}^{-1} ; \mathrm{NO}_{3}^{-} 1.45 \mathrm{mM} ; \mathrm{HCO}_{3}^{-}$

$0.120 \mathrm{mM} ; \mathrm{CO}^{2-} 0.000141 \mathrm{mM}$ ).

\section{photochamber;}

Cylindrical quartz reactor $(100 \mathrm{~mL})$ kept in a

$\mathrm{nm})$;

- Addition of DOM, $\mathrm{NO}_{3}^{-}$.

- Sealed quartz test tubes $(20 \mathrm{~mL})$

carbamazepine, $\quad-$ WW effluent $(\mathrm{pH}$ 7.85 \pm 0.21 ; DOC diuron, simazine, $\quad 11.55 \pm 2.05 \mathrm{mg} \mathrm{L}^{-1}$; COD $33.00 \pm 5.65 \mathrm{mg} \mathrm{L}^{-}$ sulfamethoxazole, $\quad{ }^{\prime} ; \mathrm{NO}_{3}^{-} 26.25 \pm 0.64 \mathrm{mg} \mathrm{L}^{-1}$; $\mathrm{UVA}_{254}$ triclosan, $\quad 2,4-\quad 0.36 \pm 0.02 \mathrm{~cm}^{-1}$; UVA254/DOC $3.10 \pm 0.28 \mathrm{~m}^{-}$ dichlorophenoxyacetic ${ }^{1} \mathrm{mg}^{-1}$ ), Victoria, Australia acid $150 \mu \mathrm{g} \mathrm{L}^{-1}$

Irradiation source: natural (average solar irradiance 7.7-9.2 $\mathrm{KW} \mathrm{m}^{-2}$ ) and simulated sunlight xenon arc lamp with an UV range of $290-400 \mathrm{~nm}$

- Effect of HA (DOC of 0, 2 and $4 \mathrm{mg} \mathrm{L}^{-1}$ ) or $\mathrm{NO}_{3}^{-}\left(10 \mathrm{mg} \mathrm{L}^{-1}\right.$ and $\left.20 \mathrm{mg} \mathrm{L}^{-1}\right)$ addition.

Monensin,

salinomycin

nigericin

$0.8-3.0 \mu \mathrm{M}$
- Deionized water (buffered at $\mathrm{pH} 7.0$ );

$\mathrm{UV} / \mathrm{H}_{2} \mathrm{O}_{2}$

W (SW)
- WW effluent ( $\mathrm{pH} 7.4$; DOC $0.435 \mathrm{mg} \mathrm{L}^{-1}$; $\mathrm{Cl}^{-} 0.41 \mathrm{mM} ; \mathrm{NO}_{3}^{-} 1.45 \mathrm{mM} ; \mathrm{PO}_{4}^{3-} 0.95$ $\mathrm{mM} ; \mathrm{HCO}_{3}^{-} 0.00011 \mathrm{mM} ; \mathrm{CO}_{3}^{2-} 0.12 \mathrm{mM}$ )
$-60 \mathrm{~mL}$ cylindrical quartz reactor with a 4-W LP UV lamp $\left(\lambda_{\max } 254 \mathrm{~nm}\right)$

- Incident light intensity $2.0 \mathrm{~mW} \cdot \mathrm{cm}^{-2}(\approx$ to a
photo fluence rate of $3.36 \times 10^{-6}$ Einstein $\left.\cdot \mathrm{L}^{-1} \cdot \mathrm{s}^{-1}\right)$

- Fluences from 0 to $6.05 \times 10^{-4}$ Einstein $\cdot \mathrm{L}^{-1}$.

$-30 \mathrm{mg} \mathrm{L}^{-1} \mathrm{H}_{2} \mathrm{O}_{2}$;

$-\mathrm{T} 22^{\circ} \mathrm{C}$.
Overall, the removal efficiencies were in the following order: $\mathrm{UP}>\mathrm{SW}>\mathrm{WW}$. $\mathrm{NO}_{3}{ }^{-}$had a positive effect in the removal of the investigated pollutants under sunlight and UV radiation, mainly by the enhancement of transformation routes involving $\mathrm{HO}^{*}$. In ultrapure and river water, $\mathrm{NO}_{3}{ }^{-}$addition reduced the compounds stability, while not significant changes were found in WW. However, reactive species could be partially consumed by DOC, reducing the removal efficiency.

The photodegradation rate of monensin was significantly increased in WW in comparison with deionized water while the photodegradation of salinomycin was not enhanced. The overall photodegradation of studied compounds in real water matrices is a result of both direct and indirect photolysis. $\mathrm{NO}_{3}^{-}$and DOM increased the photodegradation of monensin and salinomycin. An exception was found for the degradation of salinomycin in the presence of one type of DOM.

The photodegradation rates of the studied compounds were significantly greater in the WW than in the UPW, indicating they primarily degraded via indirect photolysis. However, sulfamethoxazole and triclosan were mainly degraded via direct photolysis. $\mathrm{NO}_{3}{ }^{-}$ could act as photosensitizer and produce $\mathrm{HO}^{\circ}$, promoting the photodegradation of the MPs. The addition of $\mathrm{NO}_{3}^{-}$promoted the photolysis of all compounds, with minor effect on those which indirect photolysis was not the main degradation pathway. HA enhanced the degradation of caffeine, diuron and sulfamethoxazole, inhibiting the photolysis of the other compounds.

Under UV irradiation, the degradation of the antibiotics in SW and WW was faster than in buffered DI. In this case, the degradation occurred by direct UV photolysis, whereas indirect photolysis contributed to the faster degradation in the actual matrices. Matrix components such as $\mathrm{NO}_{3}{ }^{-}, \mathrm{Cl}^{-}$and DOM may produce certain radicals and reactive transient species under UV irradiation, reacting quickly. However, the degradation rates by $\mathrm{UV} / \mathrm{H}_{2} \mathrm{O}_{2}$ were lower in $\mathrm{SW}$ and WW than in DI. The authors attributed this behaviour to matrix effects, mostly $\mathrm{HO}^{*}$ scavengers and competitors for UV absorption. Since the direct photolysis was significantly slower than the reaction of the compounds with $\mathrm{HO}^{\circ}$, the direct photolysis by UV can be considered negligible in the $\mathrm{UV} / \mathrm{H}_{2} \mathrm{O}_{2}$ process. 


\begin{tabular}{|c|c|c|c|c|c|}
\hline $\begin{array}{l}\mathbf{U V} \\
\mathbf{U V} / \mathrm{H}_{2} \mathbf{O}_{2}\end{array}$ & $\begin{array}{l}\text { Sulfamethoxazole, } \\
\text { sulfamethazine, } \\
\text { sulfadiazine, } \\
\text { trimethoprim, } \\
\text { bisphenol A, } \\
\text { diclofenac } \\
4 \mu \mathrm{M}\end{array}$ & 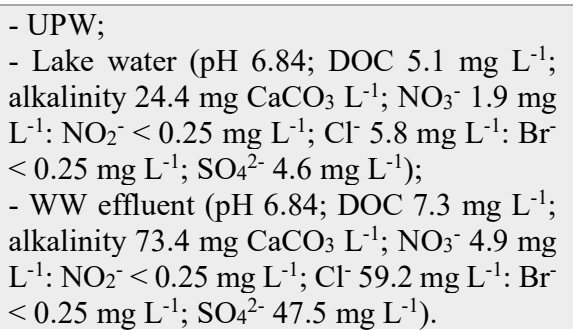 & $\begin{array}{l}\text { - Bench scale quasi-collimated beam apparatus } \\
\text { equipped with } 4 \text { LP UV lamps; } \\
\text { - pH in UPW experiments: } 3.6,7.85,9.7 \text { (only for } \\
\text { UV); } \\
\text { - pH in water matrices experiments: } 7.85 \text {; } \\
\text { - } \mathrm{H}_{2} \mathrm{O}_{2}: 2,6,10 \mathrm{mg} \mathrm{L}^{-1} \text {. }\end{array}$ & $\begin{array}{l}\mathrm{UV} / \mathrm{H}_{2} \mathrm{O}_{2} \text { treatment led to removals ranging from } 43 \% \\
\text { for trimethoprim to } 98 \% \text { for diclofenac in lake water. } \\
\text { In WW, the removals were lower }(31-97 \%) \text {, } \\
\text { suggesting a superior scavenging rate of } \mathrm{HO}^{\circ} \text {, namely } \\
\text { DOC, alkalinity, } \mathrm{Cl}^{-}, \mathrm{SO}_{4}^{2-} \text { and } \mathrm{NO}_{3}{ }^{-} \text {. }\end{array}$ & [38] \\
\hline $\mathbf{U V}$ & $\begin{array}{l}\text { Sulfamethoxazole } \\
1.0,2.0,5.0 \text { and } 10 \mathrm{mg} \\
\mathrm{L}^{-1}\end{array}$ & $\begin{array}{l}\text { - UPW; } \\
\text { - WW effluent (pH 7.0; DOC } 16 \mathrm{mg} \mathrm{L}^{-1} \text {; } \\
\text { COD } 21.2 \mathrm{mg} \mathrm{L}^{-1} \text {; turbidity } 2.0 \mathrm{NTU} \text {; } \mathrm{N}_{\text {total }} \\
23 \mathrm{mg} \mathrm{L} \mathrm{L}^{-1} \text { P Ptotal } 0.4 \mathrm{mg} \mathrm{L}^{-1} \text { ), Shanghai, } \\
\text { China. }\end{array}$ & $\begin{array}{l}-0.8 \mathrm{~L} \text { a cylindrical glass-jacketed reactor ; } \\
-10 \mathrm{~W} \text { power input } \mathrm{LP} \mathrm{Hg} \text { lamp (Shanghai, } \\
\text { China) }(\lambda \max 254 \mathrm{~nm}) \text {; } \\
- \text { Effect of organic anions }\left(\mathrm{Cl}^{-}, \mathrm{SO}_{4}{ }^{2-}, \mathrm{NO}_{3}{ }^{-} \text {, }\right. \\
\left.\mathrm{HCO}_{3}^{-}\right) \text {and HA. }\end{array}$ & 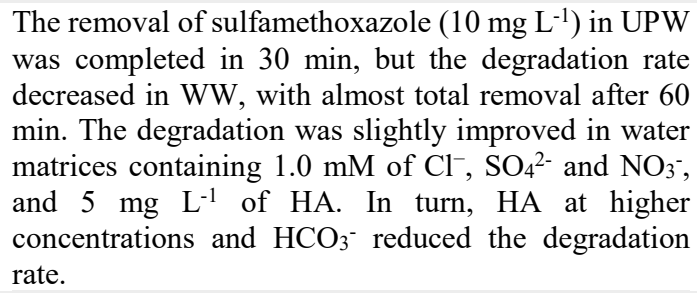 & [41] \\
\hline $\begin{array}{l}\mathbf{U V} \\
\mathbf{U V} / \mathbf{H}_{2} \mathbf{O}_{2}\end{array}$ & $\begin{array}{l}\text { Erythromycin, } \\
\text { doxycycline, } \\
\text { clindamycin, } \\
\text { ciprofloxacin, } \\
\text { penicillin-G, } \\
\text { trimethoprim } \\
0.68-1.72 \mu \mathrm{M}\end{array}$ & $\begin{array}{l}\text { - UPW; } \\
\text { - WW effluent } 1\left(\mathrm{pH} 6.84 ; \text { DOC } 5.8 \mathrm{mg} \mathrm{L}^{-}\right. \\
{ }^{\prime} ; \text { alkalinity } 123 \mathrm{mg} \mathrm{CaCO}_{3} \mathrm{~L}^{-1} ; \mathrm{NO}_{3}^{-} 4.04 \\
\left.\mathrm{mg} \mathrm{L}^{-1}: \mathrm{NO}_{2}^{-}<0.015 \mathrm{mg} \mathrm{L}^{-1}\right) ; \\
\text { - WW effluent } 1(\mathrm{pH} 6.58 ; \text { DOC } 4.9 \mathrm{mg} \mathrm{L}- \\
{ }^{-} ; \text {alkalinity } 88 \mathrm{mg} \mathrm{CaCO}_{3} \mathrm{~L}^{-1} ; \mathrm{NO}_{3}^{-} 10.3 \mathrm{mg} \\
\left.\mathrm{L}^{-1}: \mathrm{NO}_{2}^{-} 0.021 \mathrm{mg} \mathrm{L}^{-1}\right) .\end{array}$ & $\begin{array}{l}\text { - MP lamp system consisting of a } 1-\mathrm{kW} \text { lamp } \\
\text { emitting a polychromatic spectrum }>200 \mathrm{~nm} \text {; } \\
\text { - LP lamp system consisting of four } 15-\mathrm{W} \text { lamps } \\
\text { emitting monochromatic light at } \lambda 253.7 \mathrm{~nm} \text {; } \\
\text { - } \mathrm{H}_{2} \mathrm{O}_{2}: 10 \mathrm{mg} \mathrm{L}^{-1} \text {. }\end{array}$ & $\begin{array}{l}\text { Photolysis and } \mathrm{UV} / \mathrm{H}_{2} \mathrm{O}_{2} \text { experiments showed the } \\
\text { matrix influence. UV-photosensitized reactions were } \\
\text { recorded for clindamycin. In } \mathrm{UV} / \mathrm{H}_{2} \mathrm{O}_{2} \text { process, } \\
\text { erythromycin and doxycycline originated some active } \\
\text { intermediates at low treatment doses of } \mathrm{UV}_{254} \text { and only } \\
\text { in WW effluents, suggesting that these by-products } \\
\text { does not result from direct reaction with } \mathrm{HO} \text {. The } \\
\text { reactions seem to be controlled by some components } \\
\text { of the matrix by the following mechanisms: (i) reaction } \\
\text { initiated when } \mathrm{HO} \text { interact with the pollutant in the } \\
\text { presence of other matrix components; (ii) result of dark } \\
\text { reactions of photoproducts; or (iii) result from } \\
\text { photosensitized reactions in complex matrices under } \\
\text { UV, namely with }{ }^{1} \mathrm{O}_{2} \text { or }{ }^{3} \mathrm{DOM}^{*} \text {. }\end{array}$ & [19] \\
\hline $\begin{array}{l}\mathbf{U V} \\
\mathbf{U V} / \mathbf{H}_{2} \mathbf{O}_{2}\end{array}$ & $\begin{array}{l}\text { Oxytetracycline, } \\
\text { doxycycline, } \\
\text { ciprofloxacin } \\
5 \mu \mathrm{M}\end{array}$ & $\begin{array}{l}\text { - UPW; } \\
\text { - SW; } \\
\text { - DW; } \\
\text { - WW effluent (pH 7.84; DOC } 5.0 \mathrm{mg} \mathrm{L}^{-1} \text {; } \\
\text { alkalinity } 1.58 \mathrm{mM} \mathrm{HCO}_{3}^{-} ; \mathrm{NO}_{3}^{-} 132 \mathrm{mg} \mathrm{L}^{-} \\
{ }^{1} ; \mathrm{Cl}^{-} 107.3 \mathrm{mg} \mathrm{L}^{-1} ; \mathrm{F}^{-} 0.4 \mathrm{mg} \mathrm{L}^{-1} ; \mathrm{SO}_{4}^{2-} 60.7 \\
\left.\mathrm{mg} \mathrm{L}^{-1}\right) .\end{array}$ & $\begin{array}{l}\text { - } 11 \mathrm{~W} \text { LP Hg lamp emitting monochromatic light } \\
\text { at } \lambda 254 \mathrm{~nm} \text {; } \\
-\mathrm{H}_{2} \mathrm{O}_{2}: 1 \mathrm{mM} \text {. }\end{array}$ & $\begin{array}{l}\text { The performance of } \mathrm{UV} / \mathrm{H}_{2} \mathrm{O}_{2} \text { process was influenced } \\
\text { by water matrix. For all target antibiotics, the DW was } \\
\text { the matrix which led to faster degradation and the } \\
\text { opposite occurred in WW due to the higher } \\
\text { background } \mathrm{HO}^{\circ} \text { radical scavenging in this matrix. }\end{array}$ & [35] \\
\hline $\begin{array}{l}\mathbf{U V} \\
\mathbf{U V} / \mathbf{H}_{2} \mathrm{O}_{2}\end{array}$ & $\begin{array}{l}\text { 1-H-Benzotriazole, } \\
\mathrm{N}, \mathrm{N}-\text { diethyl-m- } \\
\text { toluamide (DEET), } \\
\text { Chlorophene, 3- } \\
\text { Methylindole, } \\
\text { Nortripty-line } \mathrm{HCl} \\
1 \mu \mathrm{M}\end{array}$ & 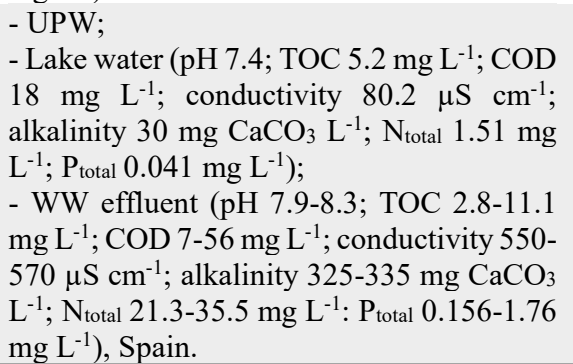 & $\begin{array}{l}\text { - Irradiation source: UV immersed LP Heraeus } \\
\text { Hg lamp TN } 15 / 35 \text { with a nominal output of } 15 \mathrm{~W} \\
\left(\lambda_{\max } 254 \mathrm{~nm}\right) \text {; } \\
-\mathrm{H}_{2} \mathrm{O}_{2}: 1 \text { and } 5 \times 10^{-5} \mathrm{M} \text {; } \\
\text { - Natural pH of each water; } \\
\text { - Temperature of } 20^{\circ} \mathrm{C} \text {. }\end{array}$ & $\begin{array}{l}\text { In the simultaneous photodegradation by UV and } \\
\mathrm{UV} / \mathrm{H}_{2} \mathrm{O}_{2} \text {, the removal rate of all compounds } \\
\text { decreased with the relative organic matter contents of } \\
\text { the different water matrices. }\end{array}$ & [42] \\
\hline
\end{tabular}




$\begin{array}{lll}\text { Benalaxyl, cyprodinil, } & \text { - Tap water; } & - \text { Middle-scale photoreactor with water } \\ \text { dimethomorph, } & \text { - Swimming pool water; } & \text { recirculation to simulate real conditions; } \\ \text { fenhexamide, } & \text { - River water; } & - \text { Irradiation source: UVC 6W lamp }(\lambda=254 \mathrm{~nm}) \\ \text { iprovalicarb, } & \text { - WW effluent (composition not provided). } & -\mathrm{H}_{2} \mathrm{O}_{2}: 20 \mathrm{mg} \mathrm{L}^{-1} .\end{array}$

iprovalicarb,

- WW effluent (composition not provided). $\quad-\mathrm{H}_{2} \mathrm{O}_{2}: 20 \mathrm{mg} \mathrm{L}^{-1}$.

Under UVC radiation, degradation occurred in all water samples and was quite similar despite of the kresoxim-methyl,

metalaxyl,

myclobutanil,

extrimately $>50 \%$

tebuconazole

(except for benalaxyl, iprovalicarb and myclobutanil) after $30 \mathrm{~min}$.

Regarding the removal efficiency by $\mathrm{UVC} / \mathrm{H}_{2} \mathrm{O}_{2}$, an average removal of $75 \%$ was verified for all the water matrices in less than $6 \mathrm{~min}$. The addition of $\mathrm{H}_{2} \mathrm{O}_{2}$ under

$10 \mu \mathrm{g} \mathrm{L}^{-1}$

UVC light allowed an improvement of the reaction

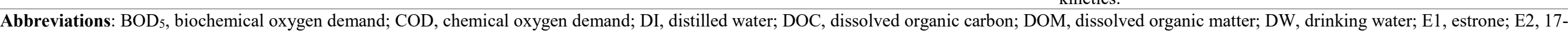

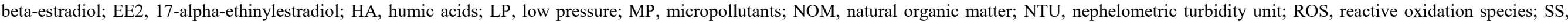

suspended solids; SW, surface water; SWW, synthetic wastewater; TC, total carbon; TOC, total organic carbon; TSS, total suspended solids; UPW, ultrapure water; WW, wastewater. 
Table S2. Reaction rate constants $(k)$.

\begin{tabular}{|c|c|c|c|}
\hline Reaction & & $\boldsymbol{k}$ & Reference \\
\hline 9 & $\mathrm{H}_{2} \mathrm{O}_{2}+\mathrm{HO}^{\bullet} \rightarrow \mathrm{HO}_{2}{ }^{\bullet}+\mathrm{H}_{2} \mathrm{O}$ & $3.3 \times 10^{7} \mathrm{M}^{-1} \mathrm{~s}^{-1}$ & {$[171]$} \\
\hline 10 & $\mathrm{H}_{2} \mathrm{O}_{2}+\mathrm{HO}_{2}{ }^{\cdot} \rightarrow \mathrm{HO}^{*}+\mathrm{O}_{2}+\mathrm{H}_{2} \mathrm{O}$ & $3 \mathrm{M}^{-1} \mathrm{~s}^{-1}$ & {$[172]$} \\
\hline 15 & $\mathrm{HO}^{\bullet}+\mathrm{HCO}_{3}^{-} \rightarrow \mathrm{H}_{2} \mathrm{O}+\mathrm{CO}_{3}{ }^{-}$ & $8.5 \times 10^{6} \mathrm{M}^{-1} \mathrm{~s}^{-1}$ & {$[173]$} \\
\hline 16 & $\mathrm{HO}^{*}+\mathrm{CO}_{3}^{2-} \rightarrow \mathrm{HO}^{-}+\mathrm{CO}_{3}{ }^{--}$ & $3.9 \times 10^{8} \mathrm{M}^{-1} \mathrm{~s}^{-1}$ & {$[173]$} \\
\hline 17 & $\mathrm{Fe}^{2+}+\mathrm{H}_{2} \mathrm{O}_{2} \rightarrow \mathrm{Fe}^{3+}+\mathrm{HO}^{-}+\mathrm{HO}^{-}$ & $76 \mathrm{M}^{-1} \mathrm{~s}^{-1}$ & {$[37]$} \\
\hline 18 & $\mathrm{Fe}^{2+}+\mathrm{HO}^{\cdot} \rightarrow \mathrm{Fe}^{3+}+\mathrm{HO}^{-}$ & $3.2 \times 10^{8} \mathrm{M}^{-1} \mathrm{~s}^{-1}$ & {$[118]$} \\
\hline 19 & $\mathrm{HO}^{\bullet}+\mathrm{RH} \rightarrow \mathrm{H}_{2} \mathrm{O}+\mathrm{R}^{\bullet}$ & $10^{7} \mathrm{M}^{-1} \mathrm{~s}^{-1}$ & {$[118]$} \\
\hline 21 & $\mathrm{Fe}^{3+}+\mathrm{H}_{2} \mathrm{O}_{2} \rightarrow \mathrm{Fe}^{2+}+\mathrm{HO}_{2}{ }^{\cdot}+\mathrm{H}^{+}$ & $0.001-0.01 \mathrm{M}^{-1} \mathrm{~s}^{-1}$ & {$[174]$} \\
\hline 41 & $\mathrm{O}_{2}^{\bullet-}+\mathrm{H}^{+} \rightarrow \mathrm{HO}_{2}^{\bullet-}$ & $2 \times 10^{9} \mathrm{M}^{-1} \mathrm{~s}^{-1}$ & {$[175]$} \\
\hline 44 & $\mathrm{O}_{3}+\mathrm{HO}^{-} \rightarrow \mathrm{HO}_{2}^{-}+\mathrm{O}_{2}($ basic $\mathrm{pH})$ & $70 \mathrm{M}^{-1} \mathrm{~s}^{-1}$ & {$[153]$} \\
\hline 45 & $\mathrm{O}_{3}+\mathrm{HO}_{2}^{-} \rightarrow \mathrm{HO}^{\bullet}+\mathrm{O}_{2}^{--}+\mathrm{O}_{2}$ & $2.8 \times 10^{6} \mathrm{M}^{-1} \mathrm{~s}^{-1}$ & [153] \\
\hline 46 & $\mathrm{O}_{3}+\mathrm{O}_{2}{ }^{--} \rightarrow \mathrm{O}_{3}^{*-}+\mathrm{O}_{2}$ & $1.6 \times 10^{9} \mathrm{M}^{-1} \mathrm{~s}^{-1}$ & {$[153]$} \\
\hline 47 & $\mathrm{O}_{3} \cdot-\mathrm{H}^{+} \leftrightarrow \mathrm{HO}_{3} \cdot(\mathrm{pH}<8)$ & $\begin{array}{c}k+=5 \times 10^{10} \mathrm{M}^{-1} \mathrm{~s}^{-1} \\
k-=3.3 \times 10^{2} \mathrm{~s}^{-1}\end{array}$ & [153] \\
\hline 48 & $\mathrm{HO}_{3}{ }^{\circ} \rightarrow \mathrm{HO}^{*}+\mathrm{O}_{2}(\mathrm{pH}<8)$ & $1.4 \times 10^{5} \mathrm{~s}^{-1}$ & {$[153]$} \\
\hline 49 & $\mathrm{O}_{3} \cdot \stackrel{\leftrightarrow}{*} \mathrm{O}^{\bullet}+\mathrm{O}_{2}(\mathrm{pH}>8)$ & $\begin{array}{c}k+=2.1 \times 10^{3} \mathrm{M}^{-1} \mathrm{~s}^{-1} \\
k-=3.3 \times 10^{9} \mathrm{~s}^{-1}\end{array}$ & {$[153]$} \\
\hline 50 & $\mathrm{O}^{\bullet}+\mathrm{H}_{2} \mathrm{O} \rightarrow \mathrm{HO}^{\bullet}+\mathrm{HO}^{-}(\mathrm{pH}>8)$ & $10^{8} \mathrm{~s}^{-1}$ & {$[153]$} \\
\hline 51 & $\mathrm{HO}^{\bullet}+\mathrm{O}_{3} \rightarrow \mathrm{HO}_{2}^{\cdot}+\mathrm{O}_{2}$ & $1 \times 10^{8} \mathrm{M}^{-1} \mathrm{~s}^{-1}-2 \times 10^{9} \mathrm{M}^{-1} \mathrm{~s}^{-1}$ & {$[153]$} \\
\hline 57 & $\mathrm{O}_{3}{ }^{--}+\mathrm{H}^{+} \rightarrow \mathrm{HO}_{3}{ }^{\cdot}$ & $5 \times 10^{10} \mathrm{M}^{-1} \mathrm{~s}^{-1}$ & {$[176]$} \\
\hline 58 & $\mathrm{HO}_{3}{ }^{\circ} \rightarrow \mathrm{O}_{2}+\mathrm{HO}^{\cdot}$ & $1.4 \times 10^{5} \mathrm{~s}^{-1}$ & {$[176]$} \\
\hline 59 & $\mathrm{HO}^{\bullet}+\mathrm{O}_{3} \rightarrow \mathrm{O}_{2}+\mathrm{HO}_{2}^{\bullet}$ & $2 \times 10^{9} \mathrm{M}^{-1} \mathrm{~s}^{-1}$ & {$[175]$} \\
\hline
\end{tabular}


Table S3. Matrix effects occurring in studies dealing with Fenton-based processes, published since 2005. Unless otherwise stated, the experimental conditions refer to the tested conditions for the evaluation of matrix effects.

\begin{tabular}{|c|c|c|c|c|c|}
\hline AOT & $\begin{array}{l}\text { Target pollutant } \\
\text { Concentration }\end{array}$ & Matrices & Experimental conditions & Main conclusions & Reference \\
\hline Fenton-like & $\begin{array}{l}\text { Bisphenol A } \\
285-14200 \mu \mathrm{g} \mathrm{L}^{-1}\end{array}$ & $\begin{array}{l}\text { - UPW; } \\
\text { - DW; } \\
\text { - GW; } \\
\text { - SW; } \\
\text { - WW effluent (pH } 8 ; \text { TOC } 7 \mathrm{mg} \mathrm{L}^{-1} \text {; } \\
\text { conductivity } 311 \mu \mathrm{S} \mathrm{cm}^{-1} ; \mathrm{Cl}^{-} 0.5 \mathrm{mg} \mathrm{L}^{-1} \text { : } \\
\mathrm{NO}_{3}^{-} 57 \mathrm{mg} \mathrm{L}^{-1} ; \mathrm{HCO}_{3}^{-} 182 \mathrm{mg} \mathrm{L}^{-1} ; \mathrm{SO}_{4}^{2-} \\
\left.30 \mathrm{mg} \mathrm{L}^{-1}\right) \text {. }\end{array}$ & $\begin{array}{l}\text { - Glass cylindrical reaction vessel; } \\
-20 \mathrm{~mL} \text { of an aqueous solution containing } \\
\text { Bisphenol A; } \\
\text { - Magnetic stirring, open air equilibrium; } \\
\text { - Catalyst: sodium persulphate (SPS) and a } \\
\text { magnetic carbon xerogel, consisting of } \\
\text { interconnected carbon microspheres with } \\
\text { embedded iron and cobalt microparticles. }\end{array}$ & $\begin{array}{l}\text { The elimination rate in UPW was always lower than in } \\
\text { any other matrices. This resulted from an interplay } \\
\text { among many effects, namely: (i) the presence of } \mathrm{HA} \text { and } \\
\text { low molecular weight organic acids (e.g., oxalate) able } \\
\text { to form complexes with iron species, promoting the } \\
\text { Fenton-like reactions; and (ii) the presence of } \\
\text { organic/inorganic species that could led to competitive } \\
\text { adsorption onto the xerogel surface, as well as } \\
\text { scavenging effects. The experiments performed in } \\
\text { spiked UPW showed that organics and } \mathrm{HCO}_{3}{ }^{-} \text {hindered } \\
\text { the degradation, by acting as scavengers of } \mathrm{SO}_{4}^{*-} \text { and } \\
\mathrm{HO}^{\circ} \text {, whereas } \mathrm{Cl}^{-}(>50 \mathrm{mg} / \mathrm{L}) \text { had a positive effect, } \\
\text { maybe due to the formation } \mathrm{Cl}_{2}{ }^{-} \text {. }\end{array}$ & {$[14]$} \\
\hline $\begin{array}{l}\text { Bio-electro- } \\
\text { Fenton }\end{array}$ & $\begin{array}{l}\text { Ketoprofen, } \\
\text { diclofenac, ibuprofen } \\
\text { and naproxen } \\
40 \mu \mathrm{g} \mathrm{L}^{-1}\end{array}$ & 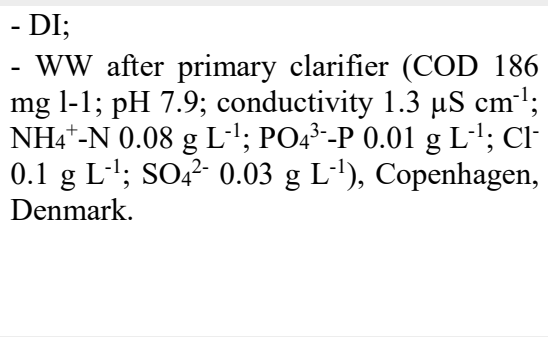 & $\begin{array}{l}\text { - Lab-scale rectangular bio-electrochemical } \\
\text { system; } \\
\text { - Reactors were maintained with } 90 \mathrm{~mL} \text { of WW; } \\
\text {-Voltage: } 0.5 \mathrm{~V} \text {; } \\
\text { - pH 2; } \\
\text { - Airflow rate: } 8 \mathrm{~mL} \mathrm{~min}^{-1} \text {; } \\
\text { - FeSO}: 5 \mathrm{mM} \text {. }\end{array}$ & $\begin{array}{l}\text { Lower removal rates were found when actual WW was } \\
\text { used as matrix. Regarding ketoprofen, diclofenac and } \\
\text { naproxen the kapp were } 30-65 \% \text { lower, which can be } \\
\text { explained by the presence of organic matter present in } \\
\text { WW competing with the targeted compounds for } \mathrm{HO}^{\circ} \text {. } \\
\text { Fenton reactions can be inhibited by inorganic ions. } \\
\text { Ferric ion can form complexes with } \mathrm{PO}_{4}^{3-} . \mathrm{SO}_{4}{ }^{2-}, \mathrm{Cl}^{-} \text {and } \\
\mathrm{F}^{-} \text {can reduce the reactivity of ferric ion. }\end{array}$ & {$[44]$} \\
\hline $\begin{array}{l}\text { Fenton } \\
\text { Fe(II)-activated } \\
\text { persulfate }\end{array}$ & $\begin{array}{l}\text { Trimethoprim } \\
0.05 \mathrm{mM}\end{array}$ & $\begin{array}{l}\text { - DI; } \\
\text { - SWW; } \\
\text { - WW effluent, Beijing. }\end{array}$ & $\begin{array}{l}\text { - Glass bottle }(150 \mathrm{~mL}) \text { fill with } 100 \mathrm{~mL} \text {; } \\
\text { - } \mathrm{Fe}^{2+}: 0.05 \mathrm{mM} \text {; } \\
\text { - } \mathrm{H}_{2} \mathrm{O}_{2}: 1 \mathrm{mM} \text {. } \\
\text { - pH } 3 \text {. }\end{array}$ & $\begin{array}{l}\text { Complete degradation of trimethoprim was obtained } \\
\text { when using DI. A decrease in the treatment efficiency } \\
\text { was found in actual WW, with } 35.8 \% \text { and } 43.6 \% \\
\text { removal for Fenton and the } \mathrm{Fe} \text { (II)-activated persulfate } \\
\text { processes, respectively. Furthermore, the } \\
\text { decomposition efficiencies for } \mathrm{H}_{2} \mathrm{O}_{2} \text { was lower in } \\
\text { comparison to DI and SWW, which may be due the } \\
\text { formation of Fe(II) complexes with organic matter } \\
\text { present in actual WW, decreasing the amount of Fe(II) } \\
\text { available for reaction with } \mathrm{H}_{2} \mathrm{O}_{2} \text {. The removal } \\
\text { efficiency in the presence of persulfate decreased in } \\
\text { WW, possibly due to the reaction between the sulphate } \\
\text { radicals and organic MPs. }\end{array}$ & {$[45]$} \\
\hline $\begin{array}{l}\text { Fenton } \\
\text { Photo-Fenton }\end{array}$ & $\begin{array}{l}\text { Prednisolone } \\
100 \mathrm{mg} \mathrm{L}^{-1}\end{array}$ & - DI; & $\begin{array}{l}\text { - Cylindrical glass reactor }(550 \mathrm{~mL}) \text {; } \\
\text { - Irradiation source: } \operatorname{LED}\left(40 \mathrm{~W}, \lambda_{\max }=360 \mathrm{~nm}\right) \text {; }\end{array}$ & $\begin{array}{l}\text { Matrix constituents affected the mineralization rates, } \\
\text { with only } 10 \% \text { removal after } 1 \text { hour treatment, while }\end{array}$ & {$[46]$} \\
\hline
\end{tabular}


Solar

irradiation

Fenton

Solar

Fenton

photo-

Carbamazepine,

clarithromycin,

diclofenac,

metoprolol,

benzotriazole

mecoprop

ng $\mathrm{L}^{-1}$ to $\mu \mathrm{g} \mathrm{L}^{-1}$ levels
- WW effluent (pH 6.9; COD $35 \mathrm{mg} \mathrm{O}_{2} \mathrm{~L}^{-}$

\section{$\begin{array}{ll}\text { Photo-Fenton } & \text { Tetracycline } \\ & 24 \mathrm{mg} \mathrm{L}^{-1}\end{array}$}

Photo-Fenton

62 MPs

3-66,379 ng L-1

Acetaminophen, caffeine,

carbamazepine,

diclofenac,

flumequine,

hydroxybiphenyl,

ibuprofen,

isoproturon,
Photo-Fenton
1; TOC $52.7 \mathrm{mg} \mathrm{L}^{-1}$; BOD $2 \mathrm{mg} \mathrm{O}_{2} \mathrm{~L}^{-1}$ :

SS $\left.12 \mathrm{mg} \mathrm{L}^{-1}\right)$, Spain.

- WW effluents with different secondary treatment, namely activated sludge $(\mathrm{pH}$ 7.8; TOC $37 \mathrm{mg} \mathrm{L}^{-1}$; COD $63 \mathrm{mg} \mathrm{L}^{-1}$ : alkalinity $273 \mathrm{mg} \mathrm{CaCO}_{3} \mathrm{~L}^{-1} ; \mathrm{Fe}_{\text {total }} 0.9 \mathrm{mg}$ $\mathrm{L}^{-1}$; TSS $12 \mathrm{mg} \mathrm{L}^{-1}$ ), moving bed bioreactor (pH 7.4; TOC $20.2 \mathrm{mg} \mathrm{L}^{-1}$; COD $35 \mathrm{mg} \mathrm{L}^{-1}$; alkalinity $85 \mathrm{mg} \mathrm{CaCO}_{3}$ $\mathrm{L}^{-1}$; Fetotal $1.6 \mathrm{mg} \mathrm{L}^{-1}$; TSS $14 \mathrm{mg} \mathrm{L}^{-1}$ ) and coagulation flocculation $(\mathrm{pH} 7.9$; TOC $57.2 \mathrm{mg} \mathrm{L}^{-1}$; COD $90 \mathrm{mg} \mathrm{L}^{-1}$ : alkalinity $231 \mathrm{mg} \mathrm{CaCO}_{3} \mathrm{~L}^{-1} ;$ Fetotal $^{1.9} \mathrm{mg} \mathrm{L}^{-1}$; TSS $30 \mathrm{mg} \mathrm{L}^{-1}$ ), Lausanne, Switzerland.

- UPW

- SW;

- WW effluent (pH 8.0; TOC 10.6 mg L-1; IC $52.4 \mathrm{mg} \mathrm{L}^{-1}$; COD $136 \mathrm{mg} \mathrm{L}^{-1}$; BOD $30.0 \mathrm{mg} \mathrm{L}^{-1}$; DO $5.0 \mathrm{mg} \mathrm{L}^{-1} ; \mathrm{Cl}^{-} 54.4 \mathrm{mg}$ $\mathrm{L}^{-1} ; \mathrm{NO}_{3}^{-} 0.73 \mathrm{mg} \mathrm{L}^{-1}$; turbidity $134 \mathrm{NTU}$; TDS $510 \mathrm{mg} \mathrm{L}^{-1}$ ), Brazil.

- WW effluent ( $\mathrm{pH}$ 7.6-8.3; TC 87-132

- Solution pH 3;

$-\mathrm{Fe}^{2+}: 3 \mathrm{mM}$;

$-\mathrm{H}_{2} \mathrm{O}_{2}: 3 \mathrm{mM}$

- 100-mL brown bottles;

$\mathrm{H}_{2} \mathrm{O}_{2}: 25 \mathrm{mg} \mathrm{L}^{-1}$;

$\mathrm{Fe}^{2+}: 5 \mathrm{mg} \mathrm{L}{ }^{-1}$.

- Iron $(0.2 \mathrm{mM})$ source: $\mathrm{Fe}\left(\mathrm{NO}_{3}\right)_{3}$ or potassium ferrioxalate;

$-\mathrm{H}_{2} \mathrm{O}_{2}: 3,10 \mathrm{mM}$;

Black-light irradiation

- Upflow reactor; V $280 \mathrm{~mL}$;

- Irradiation source: $15 \mathrm{~W}$ black-light lamp $\left(\lambda_{\max }\right.$ $365 \mathrm{~nm}$ ), with an irradiance of $19 \mathrm{~W} \mathrm{~m}^{-2}$,

- Recirculation of the solution at a flow rate of $80 \mathrm{~mL} \mathrm{~min}^{-1}$, after addition of iron, $\mathrm{pH}$ adjustment to 2.5 and addition of $\mathrm{H}_{2} \mathrm{O}_{2}$

Solar irradiation

- Transparent glass vessel; V $500 \mathrm{~mL}$;

- Direct sunlight, during summer between 10

a.m. and 14 p.m., in Brazil $\left(22^{\circ} \mathrm{S} 48^{\circ} \mathrm{W}\right)$;

- Irradiance: 15 to $20 \mathrm{~W} \mathrm{~m}^{-2}$.

- CPC plant under natural solar irradiation;

WW effluent (pH 7.6-8.3; TOC 16-18 $\mathrm{mg} \mathrm{L}^{-1}$; IC 69-116 mg L-1 ; COD 20-29 mg $\mathrm{L}^{-1}$ ), Almería, Spain.

- Stripped WW: 0.4-0.5 g $\mathrm{H}_{2} \mathrm{SO}_{4} \mathrm{~L}^{-1}$ effluent) was added to reduce $\mathrm{HCO}_{3}{ }^{-} / \mathrm{CO}_{3}{ }^{-}$content to less than $5 \mathrm{mg} \mathrm{L}^{-1}$ as IC, with no significant decrease on the $\mathrm{pH}$. $\mathrm{mg} \mathrm{L}^{-1}$; IC 69-116 $\mathrm{mg} \mathrm{L}^{-1}$; COD 20-19 mg $\left.\mathrm{L}^{-1}\right)$, Almería, Spain.

- Stripped WW: 0.4-0.5 g $\mathrm{H}_{2} \mathrm{SO}_{4} \mathrm{~L}^{-1}$ effluent was added to reduce $\mathrm{HCO}_{3}^{-} / \mathrm{CO}_{3}$ content to less than $5 \mathrm{mg} \mathrm{L}^{-1}$ as IC, with no significant decrease on the $\mathrm{pH}$.

- Fe(II): $5 \mathrm{mg} \mathrm{L}^{-1}$

$-\mathrm{H}_{2} \mathrm{O}_{2}: 50 \mathrm{mg} \mathrm{L}^{-1}$;

- Complexing agents (HA and EDDS);

- pH: 3 (classical photo-Fenton), 6.5 (modified photo-Fenton).

\section{CPC solar plant;}

Solution of Fe:EDDS (molar ratio 1:2 or 1:1);

$\mathrm{H}_{2} \mathrm{O}_{2}: 50 \mathrm{mg} \mathrm{L}^{-1}$.
- Irradiation source: solar simulator;

$50 \%$ was obtained in DI. The presence of inorganic and organic compounds in the WW may reduce the concentration of oxidant species by reacting with $\mathrm{HO}^{*}$. Regardless the type of secondary treatment, the order of degradation rates was photo-Fenton $>$ solar irradiation $>$ Fenton. In general, the higher abatement of both pollutants and TOC was reached when using effluents from moving bed bioreactor, following by activated sludge. Although the moving bed bioreactor effluents led to a higher removal by Fenton process than the other matrices, the consumption of peroxide was inferior due to the lower alkalinity, showing the $\mathrm{HCO}_{3}{ }^{-}$effect.

The SW matrix did not decrease the degradation efficiency, in comparison to UPW, under either blacklight or solar irradiation. In the case of WW under solar irradiation in the presence of ferrioxalate, no influence of the matrix was also observed. However, lower efficiency was obtained under black-light, indicating the interference of the matrix components on the efficiency of the process. This effect could be originated by the high TOC and/or IC content of $52.4 \mathrm{mg} \mathrm{L}^{-1}$ at $\mathrm{pH}$ 8. The increase of $\mathrm{H}_{2} \mathrm{O}_{2}$ resulted in an even lower efficiency, suggesting the influence of other matrix constituents.

Modified photo-Fenton with $\mathrm{HA}$ at neutral $\mathrm{pH}$ resulted in a longer treatment time required to reach a similar degradation to that observed on conventional photoFenton. Modified photo-Fenton with EDDS showed promising results, with lower consumption of $\mathrm{H}_{2} \mathrm{O}_{2}$ and keeping the $\mathrm{pH}$.

The removal rate by photo-Fenton was only slightly lower in the WW effluent than in the stripped effluent, since the first radical formed with Fe:EDDS during Fenton-like or photoactivated $\mathrm{Fe}$ is the $\mathrm{O}_{2}{ }^{*}$. The reactivity of $\mathrm{HCO}_{3}{ }^{-}$with the $\mathrm{O}_{2}{ }^{-}$is much lower than with the $\mathrm{HO}^{*}$, turning its influence negligible. 
Photo-Fenton Acetaminophen, antipyrine, atrazine, caffeine,

carbamazepine,

diclofenac,

flumequine,

hydroxybiphenyl,

ibuprofen,

isoproturon,

ketorolac, ofloxacin,

progesterone,

sulfamethoxazole and

triclosan

5 and $100 \mu \mathrm{g} \mathrm{L}^{-1}$

Ofloxacin

$10 \mathrm{mg} \mathrm{L}^{-1}$
- WW effluent (pH 7.6-8.3; DOC 10-24 Modified solar photo-Fenton;

$\mathrm{mg} \mathrm{L}^{-1}$; IC 91-120 $\mathrm{mg} \mathrm{L}^{-1}$; COD 26-63 mg - 5 $\mathrm{mg} \mathrm{L}^{-1}$ of Fe(II);

$\mathrm{L}^{-1}$ ), Almería, Spain.

$-50 \mathrm{mg} \mathrm{L}^{-1}$ of $\mathrm{H}_{2} \mathrm{O}_{2}$;

Stripped WW: $0.4-0.5$ g $\mathrm{H}_{2} \mathrm{SO}_{4} \quad \mathrm{~L}^{-1} \quad-\mathrm{pH} \approx 7$

effluent) was added to reduce - Addition of $35 \mathrm{mg} \mathrm{L}^{-1}$ oxalic acid;

$\mathrm{HCO}_{3}{ }^{-} / \mathrm{CO}_{3}{ }^{-}$content to less than $1 \mathrm{mg} \mathrm{L} \mathrm{L}^{-1}$ - Addition of $\mathrm{HA}\left(10,25,50 \mathrm{mg} \mathrm{L}^{-1}\right)$; as IC.

- Mixing 31\% of WWTP influent and $69 \%$ effluent.
Photo-Fenton

Trimethoprim

$10 \mathrm{mg} \mathrm{L}^{-1}$

$\begin{array}{ll}\text { Photo-Fenton } & \begin{array}{l}\text { Trimethoprim } \\ 10 \mathrm{mg} \mathrm{L}^{-1}\end{array} \\ & \\ \text { Fenton } & \\ & \begin{array}{l}\text { Nonionic surfactants } \\ \text { (6 alcohol ethoxylates } \\ \text { and } 4 \text { alkylphenol } \\ \text { ethoxylates }) \\ 1.4 \text { mg L }\end{array} \\ & \end{array}$

- Demineralized water;

- Simulated natural freshwater

- Simulated municipal WW;

- WW effluent (pH 7.8; DOC 10.72 mg L

1. COD $63.7 \mathrm{mg} \mathrm{L}^{-1}$; conductivity $3.05 \mu \mathrm{S}$ $\mathrm{cm}^{-1} ; \mathrm{Cl}^{-} 0.54 \mathrm{mg} \mathrm{L}^{-1} ; \mathrm{NO}_{3}^{-} 0.02 \mathrm{mg} \mathrm{L}^{-1}$; $\mathrm{SO}_{4}^{2-} 1.05 \mathrm{mg} \mathrm{L}^{-1} ; \mathrm{Na}^{+} 0.37 \mathrm{mg} \mathrm{L}^{-1} ; \mathrm{NH}_{4}^{+}$ $0.11 \mathrm{mg} \mathrm{L}^{-1} ; \mathrm{K}^{+} 0.045 \mathrm{mg} \mathrm{L}^{-1} ; \mathrm{Ca}^{2+} 0.12$ $\mathrm{mg} \mathrm{L}^{-1} ; \mathrm{Mg}^{2+} 0.064 \mathrm{mg} \mathrm{L}^{-1}$ ), Almería, Spain.

Demineralized water;

- Simulated natural freshwater

- SWW;

-WW effluent (pH 7.8; DOC $10.72 \mathrm{mg} \mathrm{L}$ ${ }^{1}$; COD $63.7 \mathrm{mg} \mathrm{L}^{-1}$; conductivity $3.05 \mu \mathrm{S}$ $\mathrm{cm}^{-1} ; \mathrm{Cl}^{-} 0.54 \mathrm{mg} \mathrm{L}^{-1}: \mathrm{NO}_{3}^{-} 0.02 \mathrm{mg} \mathrm{L}^{-1}$ $\mathrm{SO}_{4}^{2-} 1.05 \mathrm{mg} \mathrm{L}^{-1} ; \mathrm{Na}^{+} 0.37 \mathrm{mg} \mathrm{L}^{-1} ; \mathrm{NH}_{4}^{+}$ $0.11 \mathrm{mg} \mathrm{L}^{-1} ; \mathrm{K}^{+} 0.045 \mathrm{mg} \mathrm{L}^{-1} ; \mathrm{Ca}^{2+} 0.12$ $\mathrm{mg} \mathrm{L}^{-1} ; \mathrm{Mg}^{2+} 0.064 \mathrm{mg} \mathrm{L}^{-1}$ ), Almería, Spain.

UPW

- WW effluent

(pH 7.6; TOC $13 \mathrm{mg} \mathrm{L}^{-1}$; COD $42 \mathrm{mg} \mathrm{L}^{-1}$; conductivity $540 \mu \mathrm{S} \mathrm{cm}^{-1} ; \mathrm{Cl}^{-1} 124 \mathrm{mg} \mathrm{L}^{-1}$; $\mathrm{HCO}_{3}{ }^{-} 232 \mathrm{mg} \mathrm{L}^{-1} \cdot \mathrm{Na}^{+} 74 \mathrm{mg} \mathrm{L}^{-1} \cdot \mathrm{Ca}^{2+} 77$ $\left.\mathrm{mg} \mathrm{L}^{-1} ; \mathrm{Mg}^{2+} 11 \mathrm{mg} \mathrm{L}^{-1}\right)$, Como, Italy.
- CPC plant under natural solar irradiation;

- $\mathrm{pH} 2.8-2.9$

- Fe(II): $2 \mathrm{mg} \mathrm{L}^{-1}$;

$-\mathrm{H}_{2} \mathrm{O}_{2}: 2.5 \mathrm{mg} \mathrm{L}^{-1}$

- CPC plant under natural solar irradiation

- $\mathrm{pH} 2.8-2.9$

- Fe(II): $2 \mathrm{mg} \mathrm{L}^{-1}$;

$-\mathrm{H}_{2} \mathrm{O}_{2}: 2.5 \mathrm{mg} \mathrm{L}^{-1}$

- $29 \mathrm{ml}$ of solution in $40 \mathrm{ml}$ glass vials to which acidic $\mathrm{Fe}(\mathrm{II})$ sulphate solution and $\mathrm{H}_{2} \mathrm{O}_{2}$ were added;

$-\mathrm{H}_{2} \mathrm{O}_{2} / \mathrm{Fe}$ ratio: 1.4 ;

$\mathrm{Fe}^{2+}: 14 \mathrm{mg} \mathrm{L}^{-1}$ (WW) and $10.5 \mathrm{mg} \mathrm{L}^{-1}$ (UPW)

$-\mathrm{H}_{2} \mathrm{O}_{2}: 12 \mathrm{mg} \mathrm{L}^{-1}$ (WW) and $9 \mathrm{mg} \mathrm{L}^{-1}$ (UPW); - pH range: $3-4$.
The use of ferrioxalate, humic substances and mixing the WWTP effluent with a percentage of influent, were attempted to form photoactive Fe(III) complexes. Both oxalate- and HA-enhanced processes provided higher degradation of MPs, but mixing influent was not successful.
The process was efficient to remove ofloxacin. DOC removal and the formation of by-products were dependent on the chemical composition of the matrix, with a lower mineralization of ofloxacin observed in the WW, due to the higher concentration of inorganic (i.e. $\mathrm{Cl}^{-}$and $\mathrm{SO}_{4}{ }^{2-}$ ) and organic species in the more complex matrix. The presence of inorganic ions in the simulated natural freshwater also affected the mineralization.

In comparison to demineralized water and simulated natural freshwater, the higher organic carbon and salt content in simulated/real effluents reduced the mineralization per dose of $\mathrm{H}_{2} \mathrm{O}_{2}$. A slightly higher amount of $\mathrm{H}_{2} \mathrm{O}_{2}$ was required in the case of simulated freshwater. The organic/inorganic content of WW competed with the target pollutant and interfered with its degradation pathways.

The efficiency of Fenton process decreased when using the real effluents and higher doses of reactants were required in order to achieve the same removal reached in UPW, maintaining the $\mathrm{H}_{2} \mathrm{O}_{2}$ Fe ratio. 
- WW effluent (pH 7.4; DOC $16.5 \mathrm{mg} \mathrm{L}^{-1}$; conductivity $602 \mu \mathrm{S} \mathrm{cm}^{-1} ; \mathrm{Cl}^{-} 295.7 \mathrm{mg} \mathrm{L}^{-}$

${ }^{1}$; $\mathrm{NO}_{3}{ }^{-} 42.0 \mathrm{mg} \mathrm{L}^{-1}$; $\mathrm{SO}_{4}^{2-} 128.6 \mathrm{mg} \mathrm{L}^{-1}$. $\mathrm{PO}_{4}{ }^{3-} 6.2 \mathrm{mg} \mathrm{L}^{-1} ; \mathrm{Na}^{+} 172.2 \mathrm{mg} \mathrm{L}^{-1} ; \mathrm{NH}_{4}{ }^{+}$ $22.6 \mathrm{mg} \mathrm{L}^{-1} ; \mathrm{K}^{+} 24.8 \mathrm{mg} \mathrm{L}^{-1} ; \mathrm{Ca}^{2+} 79.8 \mathrm{mg}$ $\mathrm{L}^{-1} ; \mathrm{Mg}^{2+} 26.1 \mathrm{mg} \mathrm{L}^{-1}$; turbidity 10.7 NTU), Almería, Spain.

\section{Photo-Fenton}

Acetaminophen,

- Synthetic water;

antipyrine, atrazine, - Simulated effluent;

caffeine,

carbamazepine,

diclofenac,

flumequine,

hydroxybiphenyl,

ibuprofen,

isoproturon,

ketorolac, ofloxacin,

progesterone,

sulfamethoxazole and

triclosan

$100 \mu \mathrm{g} \mathrm{L}^{-1}$

Fenton

Hydroquinone

$100 \mathrm{mg} \mathrm{L}^{-1}$

Fenton

\section{MPs}

ng $L^{-1}-\mu g L^{-1}$ levels

- WW effluent (DOC $25 \mathrm{mg} \mathrm{L}^{-1}$; IC 106

$\mathrm{mg} \mathrm{L}^{-1}$; COD $60 \mathrm{mg} \mathrm{L}^{-1}$ ), Almería, Spain.

\section{- DI;}

- WW effluent 2 (pH 7.6, TOC 88.9 mg L ${ }^{1}$; COD $308.7 \mathrm{mg} \mathrm{L}^{-1}$; TN $12.14 \mathrm{mg} \mathrm{L}^{-1}$; TP $13.22 \mathrm{mg} \mathrm{L}^{-1}$; TSS $22.0 \mathrm{mg} \mathrm{L}^{-1} ; \mathrm{NO}_{3}^{-}<$ $\left.0.18 \mathrm{mg} \mathrm{L}^{-1} ; \mathrm{NO}_{2}^{-} 0.007 \mathrm{mg} \mathrm{L}^{-1}\right)$, Portugal. - WW effluent $1\left(\mathrm{pH} \approx 7\right.$, DOC $3-5 \mathrm{mg} \mathrm{L}^{-}$ ; $\mathrm{COD} 25 \mathrm{mg} \mathrm{L}^{-1}$; $\mathrm{BOD}_{5}<5 \mathrm{mg} \mathrm{L}^{-1}$; TN 20-30 mg L-1; TP 10-14 mg L-1; TSS 35 $\mathrm{mg} \mathrm{L}^{-1} ;(49-51 \mathrm{MPs}$ detected up to $3770 \mathrm{ng}$ $\left.\mathrm{L}^{-1}\right)$, Mexico;

- WW effluent $2\left(\mathrm{pH} \approx 7\right.$, DOC $2-4 \mathrm{mg} \mathrm{L}^{-}$ ${ }^{1}$; COD 20-35 mg L${ }^{-1}$; BOD $_{5}<5 \mathrm{mg} \mathrm{L}^{-1}$ TN 6-8 mg L-1; TP 4-10 $\mathrm{mg} \mathrm{L}^{-1}$; TSS $9 \mathrm{mg}$ $\mathrm{L}^{-1} ; 11-16 \mathrm{MPs}$ detected up to $210 \mathrm{ng} \mathrm{L}^{-1}$ ), Mexico.

Fenton E1, E2, EE2, - WW effluents from 3 different locations; carbamazepine,

triclosan and

acetylsalicylic acid ng L ${ }^{-1}$ to $\mu \mathrm{g} \mathrm{L}^{-1}$ levels
PC reactor under solar irradiation;

$\mathrm{H}_{2} \mathrm{O}_{2}: 0-50 \mathrm{mg} \mathrm{L}^{-1}$

Iron: $5 \mathrm{mg} \mathrm{L}^{-1}$;

Unchanged $\mathrm{pH}$;

Addition of $406 \mathrm{mg} \mathrm{L}^{-1} \mathrm{H}_{2} \mathrm{SO}_{4}$ to reach an IC $<$ $20 \mathrm{mg} \mathrm{L}^{-1}$

- Bubble column reactor $(10 \mathrm{~L})$ fill with $5 \mathrm{~L}$;

$\mathrm{Fe}^{2+}: 45 \mathrm{mg} \mathrm{L}{ }^{-1}$

$-\mathrm{H}_{2} \mathrm{O}_{2}: 500 \mathrm{mg} \mathrm{L}^{-1}$

- Continuous stir tank reactor $\left(31.34 \mathrm{dm}^{-3}\right)$ containing the modified polyacrylonitrile (PAN) catalyst, corresponding to 1.31 moles of iron catalyst;

- Residence time $3 \mathrm{~h}$;

- Flow rate $10.6 \mathrm{~L} \mathrm{~h}^{-1}$

$-\mathrm{H}_{2} \mathrm{O}_{2}$ mass flow rate $4.7 \mathrm{mg} \min ^{-1}$,
Sulfamethoxazole was completely removed from all matrices by Solar Fenton, with a removal of $93 \%$ in actual effluents $\left(\mathrm{t}_{30} \mathrm{~W}, \mathrm{n}=250 \mathrm{~min}\right)$ and a complete removal in simulated effluents $\left(\mathrm{t}_{30} \mathrm{w}, \mathrm{n}=198 \mathrm{~min}\right)$ and DI $\left(\mathrm{t}_{30} \mathrm{w}, \mathrm{n}=85 \mathrm{~min}\right)$. A lower removal $(77 \%)$ was observed for clarithromycin at the end of the treatment time $\left(\mathrm{t}_{30} \mathrm{~W}, \mathrm{n}=252 \mathrm{~min}\right)$, but it was totally eliminated in the other matrices. The lower removal in the real effluents was related to the high concentrations of DOM and inorganic ions, specifically $\mathrm{Cl}^{-}$and $\mathrm{SO}_{4}{ }^{2-}$ anions that can complex iron and scavenge $\mathrm{HO}^{\circ}$, forming less oxidative radicals $\left(\mathrm{Cl}_{2}{ }^{-}\right.$and $\left.\mathrm{SO}_{4}{ }^{--}\right)$, compared to $\mathrm{HO}^{\circ}$. The MPs were successfully degraded to negligible concentrations with mild solar photo-Fenton at low iron concentrations $\left(5 \mathrm{mg} \mathrm{L}^{-1}\right)$ and $50 \mathrm{mg} \mathrm{L}^{-1}$ of $\mathrm{H}_{2} \mathrm{O}_{2}$, without adjusting the $\mathrm{pH}$. The degradation was dependent on the type of matrix and scavengers present in the matrix, such as $\mathrm{CO}_{3}{ }^{2-}$ and $\mathrm{HCO}_{3}{ }^{-}$. The removal was faster in the WW effluent than in the simulated one, but the DOC decrease was similar, which suggests that HA present in the actual matrix might produce solvated electrons and $\mathrm{HO}^{\circ}$ upon irradiation.

No reduction in terms of MP removal from WW and mineralization was observed, in comparison to the solution prepared in DI.

The use of Fenton as post-treatment of secondary effluents from WWTPs increased the removal efficiencies of various contaminants up to $100 \%$, but some compounds such as metformin (44\%) and dehydronifedipine (29-71\%, depending on the effluent), were not completely removed. The Fenton process was more efficient to treat the WW effluent 2, since WW effluent 1 had a higher content of the main chemical parameters and MPs analysed.

A modified PAN catalyst system was effective in the removal of the target pollutants in $\mathrm{WW}$, at ambient temperature and natural $\mathrm{pH}:>80 \%$ of the estrogens were removed; $>84 \%$ of triclosan; $46-84.5 \%$ of carbamazepine; depending on the sampling location and consequent different characteristics of the WW effluents. 


\begin{tabular}{|c|c|c|c|c|}
\hline & & & - Room temperature; natural $\mathrm{pH}$. & \\
\hline $\begin{array}{l}\mathrm{UV} / \mathrm{H}_{2} \mathrm{O}_{2} \\
\text { Photo-Fenton }\end{array}$ & $\begin{array}{l}\text { Gabapentin, } \\
\text { metformin, } \\
\text { metoprolol, atenolol, } \\
\text { clarithromycin, } \\
\text { primidone, } \\
\text { methylbenzotriazole, } \\
\text { and benzotriazole } \\
2 \mu \mathrm{M}\end{array}$ & 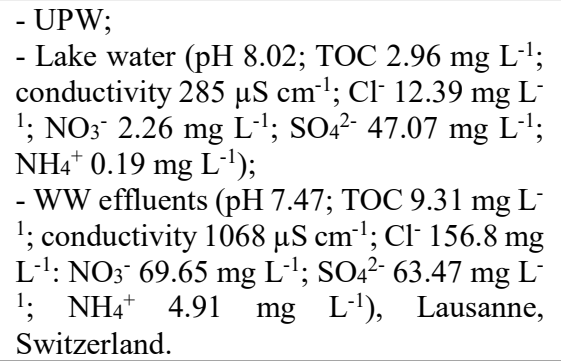 & $\begin{array}{l}\text { - UVC light LP Hg lamp }\left(\left(\lambda_{\max } 365 \mathrm{~nm}\right) \text {; }\right. \\
\text { - Solar UV-simulator: irradiation source } 1.8 \mathrm{~kW} \\
\text { Xe lamp; } \\
\text { - } \mathrm{Fe}(\mathrm{II}): 30 \mu \mathrm{M} \text {; } \\
\text { - } \mathrm{H}_{2} \mathrm{O}_{2}: 300 \mu \mathrm{M} \text {. }\end{array}$ & $\begin{array}{l}\text { The lower removal was observed in WWTP effluents } \\
\text { and lake water, which was suggested to be due to light } \\
\text { absorption at } 253.7 \mathrm{~nm} \text { and competition for } \mathrm{HO}^{*} \text { by } \\
\text { scavengers occurring in water (e.g., } \mathrm{CO}_{3}^{2-}, \mathrm{Cl}^{-} \text {, or } \\
\text { humic-like substances). The high } \mathrm{Cl}^{-} \text {content in the } \\
\text { WWTP effluent was suggested to originate coordinating } \\
\text { effect over ferric ions. }\end{array}$ \\
\hline
\end{tabular}

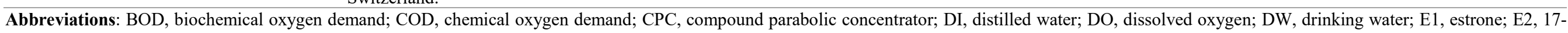

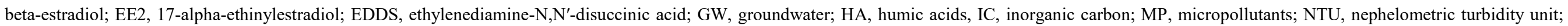

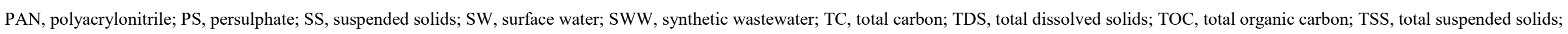

UPW, ultrapure water; WW, wastewater; WWTP, wastewater treatment plant. 
Table S4. Matrix effects occurring in studies dealing with photocatalysis, published since 2005. Unless otherwise stated, the experimental conditions refer to the tested conditions for the evaluation of matrix effects.

\begin{tabular}{|c|c|c|c|c|c|}
\hline AOT & $\begin{array}{l}\text { Target pollutant } \\
\text { Concentration }\end{array}$ & Matrices & Experimental conditions & Main conclusions & Reference \\
\hline Photocatalysis & $\begin{array}{l}\text { Diclofenac } \\
5-20 \mathrm{mg} \mathrm{L}^{-1}\end{array}$ & $\begin{array}{l}\text { - DI; } \\
\text { - GW (characterization not provided), Cyprus; } \\
\text { - WW effluent (characterization not provided), Cyprus. }\end{array}$ & $\begin{array}{l}\text { - Immersion well reactor; } \\
\text { - V } 350 \mathrm{~mL} \text {; } \\
\text { - T } 23^{\circ} \mathrm{C} \text {; } \mathrm{pH} 6 \text {; } \\
\text { - Irradiation source: } 9 \mathrm{~W} \text { UV-A lamp } \\
(350-400 \mathrm{~nm}) \text {; } \\
\text { - } \mathrm{TiO}_{2}: \mathrm{TOC} \text { ratio: } 79(\mathrm{GW}) \text { and } 32(\mathrm{WW}) \text {; } \\
\text { - } \mathrm{H}_{2} \mathrm{O}_{2}: \mathrm{TOC} \text { ratio: } 0.8(\mathrm{GW}) \text { and } 0(\mathrm{WW})\end{array}$ & $\begin{array}{l}\mathrm{UV}-\mathrm{A} / \mathrm{TiO}_{2} \text { was efficient for the } \\
\text { degradation and mineralization of } \\
\text { diclofenac in treated municipal } \\
\text { effluents. NOM and other species } \\
\text { present in the effluent reduced the } \\
\text { degradation in comparison with DI. } \\
\text { The effect of water matrix on } \\
\text { mineralization was negligible since } \\
\text { the TOC reduction was } 45 \pm 5 \% \\
\text { regardless the matrix and the addition } \\
\text { or not of } \mathrm{H}_{2} \mathrm{O}_{2} \text {. TOC analysis showed } \\
\text { that macromolecules (e.g., humic and } \\
\text { fulvic acids, biopolymers) were } \\
\text { stable to the AOT. }\end{array}$ & {$[32]$} \\
\hline Photocatalysis & $\begin{array}{l}\text { Clofibric acid } \\
1 \mathrm{mg} \mathrm{L}^{-1}\end{array}$ & $\begin{array}{l}\text { - DI; } \\
\text { - WW effluent (pH 7.54; conductivity } 818 \mu \mathrm{S} \mathrm{cm}^{-1} \text {; TOC } \\
27.1 \mathrm{mg} \mathrm{L}^{-1} \text { ). }\end{array}$ & $\begin{array}{l}\text { - } 150 \mathrm{~mL} \text { reaction cells; } \\
\text { - Irradiation source: } \mathrm{UV} \text {-A lamp }(\lambda 365 \mathrm{~nm} \text {, } \\
\left.0.89 \mathrm{~mW} \mathrm{~cm}^{-2}\right) \text {; } \\
\text { - Catalyst: } 500 \mathrm{mg} \mathrm{L}^{-1} \text { of Aeroxide } \mathrm{P} 25 \text { and } \\
\mathrm{P} 90 \text { and titania-P25/silica particles; } \\
\text { - Addition of inorganic }\left(\mathrm{NaCl}_{2} \mathrm{FeCl}_{3} \text {, }\right. \\
\mathrm{FeCl}_{2}, \mathrm{AlCl}_{3}, \mathrm{CaCl}_{2}, \mathrm{Al}_{2}\left(\mathrm{SO}_{4}\right)_{3}, \mathrm{Fe}_{2}\left(\mathrm{SO}_{4}\right)_{3} \text {, } \\
\left.\mathrm{Na}_{2} \mathrm{SO}_{4}, \quad \mathrm{NaHCO}_{3}, \text { and } \mathrm{Na}_{2} \mathrm{CO}_{3}\right) \text { or } \\
\text { organic compounds (HA, surfactant). }\end{array}$ & $\begin{array}{l}\text { Generally, the removal efficiency } \\
\text { decreased by adding inorganic salts to } \\
\text { UPW, especially } \mathrm{SO}_{4}^{2-} \text { and } \mathrm{CO}_{3}^{2-} \\
\text { ions, which are good scavengers of } \\
\text { ROS, leading to more than } 70 \% \text { of } \\
\text { deactivation. Overall, the } \\
\text { environmental waters led to a higher } \\
\text { deactivation }(>90 \%) \text {. }\end{array}$ & {$[58]$} \\
\hline Photocatalysis & $\begin{array}{l}\text { Acetaminophen, antipyrine, } \\
\text { atrazine, carbamazepine, } \\
\text { diclofenac, flumequine, } \\
\text { hydroxybiphenyl, ibuprofen, } \\
\text { isoproturon, ketorolac, } \\
\begin{array}{l}\text { ofloxacin, progesterone, } \\
\text { sulfamethoxazole, triclosan } \\
100 \mu \mathrm{g} \mathrm{L}^{-1}\end{array}\end{array}$ & $\begin{array}{l}\text { - Simulated water; } \\
\text { - SWW; } \\
\text { - WW effluent (DOC } 13 \text { mg L-1), Almería, Spain. }\end{array}$ & $\begin{array}{l}\text { - CPC solar pilot plant; } \\
\text { - Catalyst: } \mathrm{TiO}_{2} \text { immobilized on a glass } \\
\text { substrate; } \\
\text { - Natural } \mathrm{pH} \text {. }\end{array}$ & $\begin{array}{l}\text { MPs were removed using } \\
\text { immobilized } \mathrm{TiO}_{2} \text { under solar } \\
\text { irradiation in the following order of } \\
\text { efficiency removal: simulated water } \\
>\text { simulated } \mathrm{WW}>\mathrm{WW} \text { effluent. The } \\
\text { photocatalyst remained active even } \\
\text { after five cycles of reuse and } \\
\text { degraded most of the MPs in the } \\
\text { actual WW, however the time } \\
\text { required was longer. }\end{array}$ & {$[59]$} \\
\hline
\end{tabular}


Photocatalysis

$\mathrm{UV} / \mathrm{H}_{2} \mathrm{O}_{2}$

Alprazolam, clonazepam, - UPW;

diazepam, lorazepam, and

Carbamazepine

$100 \mu \mathrm{g} \mathrm{L}{ }^{-1}$
- WW effluent (pH 7.55; COD 37.2 mg L-1; IC $3.72 \mathrm{mg} \mathrm{L}^{-}$ ${ }^{1}$; TOC $37.14 \mathrm{mg} \mathrm{L}^{-1} ; \mathrm{N}_{\text {total }} 17.18 \mathrm{mg} \mathrm{L}^{-1}$; conductivity $506.0 \mu \mathrm{S} \mathrm{cm}^{-3}$; turbidity $11.13 \mathrm{NTU}$; DO $6.1 \mathrm{mg} \mathrm{L}^{-1}$; alkalinity $133.0 \mathrm{mg} \mathrm{L}^{-1}$; TS $281.0 \mathrm{mg} \mathrm{L}^{-1}$; VSS $121.0 \mathrm{mg}$ $\mathrm{L}^{-1}$; Total fixed solids $160.0 \mathrm{mg} \mathrm{L}^{-1} ; \mathrm{Cl}^{-} 54.3 \mathrm{mg} \mathrm{L}^{-1} ; \mathrm{NO}_{3}{ }^{-}$ $1.8 \mathrm{mg} \mathrm{L}^{-1} ; \mathrm{F}^{-} 0.6 \mathrm{mg} \mathrm{L}^{-1} ; \mathrm{PO}_{4}^{3-} 26.4 \mathrm{mg} \mathrm{L}^{-1} ; \mathrm{SO}_{4}{ }^{2-} 28.4$ $\mathrm{mg} \mathrm{L}^{-1}$ ), Rio de Janeiro, Brazil.

- UPW (pH 6, , conductivity $0.56 \mu \mathrm{S} \mathrm{cm}^{-1}$ ); - Bottled water ( $\mathrm{pH} 7.5$, conductivity $396 \mu \mathrm{S} \mathrm{cm}^{-1}, \mathrm{HCO}_{3}$ $15 \mathrm{mg} \mathrm{L}^{-1}, \mathrm{SO}_{4}{ }^{2-} 15 \mathrm{mg} \mathrm{L}^{-1}, \mathrm{Cl}^{-} 9.8 \mathrm{mg} \mathrm{L}^{-1}$ );

- River water ( $\mathrm{pH} 7.5$, conductivity $491 \mu \mathrm{S} \mathrm{cm}^{-1}$, TOC 2.7 $\left.\mathrm{mg} \mathrm{L}-1, \mathrm{SO}_{4}^{2-} 274 \mathrm{mg} \mathrm{L}^{-1}, \mathrm{Cl}^{-} 5 \mathrm{mg} \mathrm{L}^{-1}\right)$, Athens, Greece - Diluted WW (50\% water);

- WW effluent (pH 8, TOC $7 \mathrm{mg} \mathrm{L}^{-1}$, TSS $1.1 \mathrm{mg} \mathrm{L}^{-1}$, COD

$21 \mathrm{mg} \mathrm{L}^{-1}$, conductivity $311 \mu \mathrm{S} \mathrm{cm}^{-1}, \mathrm{SO}_{4}{ }^{2-} 30 \mathrm{mg} \mathrm{L}^{-1}, \mathrm{Cl}^{-}$ $\left.0.44 \mathrm{mg} \mathrm{L}^{-1}\right)$, Patras, Greece.
Batch magnetically stirred reactor (500 $\mathrm{mL}$ );

-Irradiation source: Polychromatic high pressure $125 \mathrm{~W}$ mercury vapor lamp $(\lambda$ m $=365 \mathrm{~nm}$ ) and solar radiation;

- Catalyst: $0.1,0.05$, and $0.005 \mathrm{~g} \mathrm{~L}^{-1} \mathrm{TiO}_{2}$ $-\mathrm{H}_{2} \mathrm{O}_{2}: 250,200,100,50,25$, and $10 \mathrm{mg}$ $\mathrm{L}^{-1}$

- Glass cylindrical vessel $(120 \mathrm{~mL})$;

- Catalyst: $500 \mathrm{mg} \mathrm{L}^{-1}$ of $\mathrm{Al}$-doped $\mathrm{TiO}_{2}$

- Solar simulator equipped with a $100 \mathrm{~W}$ xenon ozone-free lamp.

Pyrex glass cells $(5 \mathrm{~mL})$;

- $\mathrm{ZnO}$ based materials and enzyme hybrid materials $\left(1 \mathrm{~g} \mathrm{~L}^{-1}\right)$;

- Irradiation source: 40 Watt Philips

TLK/05 lamp $\left(\lambda_{\max }=365 \mathrm{~nm}\right)$;

Soybean peroxidase $\left(1 \times 10^{-8} \mathrm{M}\right)$;

$-\mathrm{H}_{2} \mathrm{O}_{2}: 1 \times 10^{-4} \mathrm{M}$.

- 11W UV LED $(\lambda=365410$ or $523 \mathrm{~nm})$

Photocatalysis

$1000 \mu \mathrm{g} \mathrm{L}-1$

- UPW;

Photocatalysis

Bisphenol A, EE2 100-300 $\mu \mathrm{g} \mathrm{L}^{-1}$
- SWW (pH 7.41; conductivity $56.3 \mu \mathrm{S} \mathrm{cm}$-1; $^{-1}$ DOC 5.40 $\mathrm{mg} \mathrm{L}^{-1}$; IC $3.71 \mathrm{mg} \mathrm{L}^{-1}$; COD $23.6 \mathrm{mg} \mathrm{L}^{-1}$; alkalinity 6.0 $\mathrm{mg} \mathrm{CaCO}_{3} \mathrm{~L}^{-1} ; \mathrm{Cl}^{-} 1.47 \mathrm{mg} \mathrm{L}^{-1} ; \mathrm{SO}_{4}^{2-} 6.95 \mathrm{mg} \mathrm{L}^{-1} ; \mathrm{PO}_{4}{ }^{3-}$ $3.82 \mathrm{mg} \mathrm{L}^{-1} ; \mathrm{NO}_{3}^{-} 0.34 \mathrm{mg} \mathrm{L}^{-1} ; \mathrm{NO}_{2}^{-} 0.04 \mathrm{mg} \mathrm{L}^{-1} ; \mathrm{Br}^{-} 0.65$

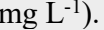

- WW effluent ( $\mathrm{pH} 7.55$, conductivity $621 \mu \mathrm{S} \mathrm{cm}^{-1}$; DOC $8.04 \mathrm{mg} \mathrm{L}^{-1}$; IC $39.23 \mathrm{mg} \mathrm{L}^{-1}$; COD $26.2 \mathrm{mg} \mathrm{L}^{-1}$; alkalinity $27.5 \mathrm{mg} \mathrm{CaCO} \mathrm{L}^{-1} ; \mathrm{Cl}^{-} 32.68 \mathrm{mg} \mathrm{L}^{-1} ; \mathrm{SO}_{4}{ }^{2-} 33.03 \mathrm{mg} \mathrm{L}^{-1}$; $\mathrm{PO}_{4}{ }^{3-} 0.21 \mathrm{mg} \mathrm{L}^{-1} ; \mathrm{NO}_{3}^{-} 36.30 \mathrm{mg} \mathrm{L}^{-1} ; \mathrm{NO}_{2}^{-}$n.d.; $\mathrm{Br}^{-} 0.54$ $\left.m g L^{-1}\right)$, Sidney.

laced $5 \mathrm{~cm}$ above the liquid reactor;

$500 \mathrm{~mL}$

$50 \mathrm{mg} \mathrm{L} \mathrm{L}^{-1}$ of catalyst (gold-modified $\mathrm{TiO}_{2}\left(\mathrm{Au}-\mathrm{TiO}_{2}\right)$ or $\left.\mathrm{TiO}_{2} \mathrm{P} 25\right)$.

\section{- UPW} - WW effluent (pH 8; conductivity $820 \mu \mathrm{S} \mathrm{cm}^{-1}$; DOC 7.8 - $150 \mathrm{~W}$ xenon lamp (solar radiation $\mathrm{mg} \mathrm{L}{ }^{-1}$; $\mathrm{COD} 24 \mathrm{mg} \mathrm{L}{ }^{-1}$; $\mathrm{Cl}^{-} 220 \mathrm{mg} \mathrm{L}^{-1}$; $\mathrm{SO}_{4}^{2-} 60 \mathrm{mg} \mathrm{L}^{-1}$; simulator: 5\% UV-A radiation, $0.1 \% \mathrm{UV}$ - strong matrix effect was found when WW effluents were used, with a decrease in efficiency of approximately $50 \%$. This effect might be due to the presence of adical scavenger species such as, $\mathrm{DOC}, \mathrm{CO}_{3}{ }^{2-}$ and anions. These species can also absorb UV light decreasing the activation of $\mathrm{TiO}_{2}$ and $\mathrm{H}_{2} \mathrm{O}_{2}$. Moreover, anions can compete for the absorption site on the catalyst. Water matrix played a considerable role on the degradation efficiency, decreasing with an increase of water matrix complexity. HA decreased greatly the degradation of propyl paraben, since it has high light absorbing capacity and can also occupy the active sites of the catalyst. Other organics can also compete for oxidizing species. A slightly negative effect was found for $\mathrm{HCO}_{3}^{-}$and $\mathrm{Cl}^{-}$. Moreover, the performance was enhanced in the presence of persulfate.

A complete removal of all studied compounds was found for both matrices, however a loss of efficiency was found when using WW, mainly due to the presence of DOM and inorganic ions.

The $\mathrm{Au}-\mathrm{TiO}_{2}$ catalyst showed better photocatalytic activity than $\mathrm{P} 25 \mathrm{TiO}_{2}$, for all the water matrices under all light sources. The removal rate of E1 decreased in the order: ultrapure > synthetic water $\approx$ WW. The differences between UPW and actual matrices were attributed to the NOM whereas the lower removal in WW was ascribed to the higher content of anions in comparison to synthetic water.

Degradation in WW was estimated as one order of magnitude lower than those obtained for UPW, which was attributed to the scavenging of $\mathrm{HO}^{*}$ by 
$\mathrm{HCO}_{3}^{-} 188 \mathrm{mg} \mathrm{L}{ }^{-1} ; \mathrm{NO}_{3}^{-} 26 \mathrm{mg} \mathrm{L}^{-1} ; \mathrm{NO}_{2}^{-} 57 \mathrm{mg} \mathrm{L}^{-1}$ ), Greece.

\begin{tabular}{|c|c|c|}
\hline Photocatalysis & $\begin{array}{l}\text { Bisphenol A } \\
100 \mu \mathrm{g} \mathrm{L}^{-1}\end{array}$ & 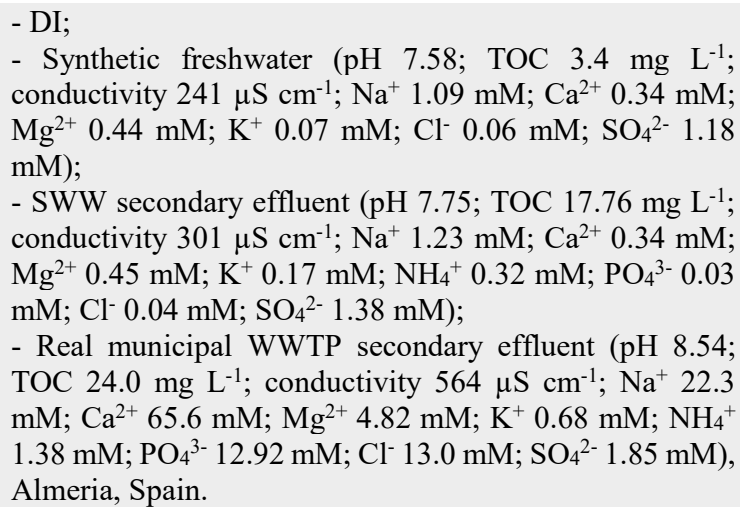 \\
\hline Photocatalysis & $\begin{array}{l}\text { Amoxicillin }\left(10 \mathrm{mg} \mathrm{L}^{-1}\right) \text {, } \\
\text { carbamazepine }\left(5 \mathrm{mg} \mathrm{L}^{-1}\right) \text {, } \\
\text { diclofenac }\left(2.5 \mathrm{mg} \mathrm{L}^{-1}\right)\end{array}$ & $\begin{array}{l}\text { - DI; } \\
\text { - WW effluent (pH 8.1; TOC } 4.51 \mathrm{mg} \mathrm{L}^{-1} \text {; BOD } 510 \mathrm{mg} \mathrm{L}^{-} \\
\left.\text {1; TSS } 11 \mathrm{mg} \mathrm{L}^{-1}\right) \text {, Italy. }\end{array}$ \\
\hline
\end{tabular}

Photocatalysis

$\mathrm{EE} 2$
$100 \mu \mathrm{g} \mathrm{L^{-1 }}$

B radiation, equipped with a $280 \mathrm{~nm}$ cutoff);

- Incident photon flux $58 \times 10^{-8}$ einstein L${ }^{1} \mathrm{~s}^{-1}$ - $\left[0.5 \% \mathrm{Pt} / \mathrm{TiO}_{2}\right]=500 \mathrm{mg} \mathrm{L}{ }^{-1}$ (ten titania
catalysts were synthesized, characterized and tested);

- T $25^{\circ} \mathrm{C}$; Matrix inherent pH (i.e., ca. 8 for WW and 6.2 for UPW)

- CPC solar pilot plant;

- Catalyst: $\mathrm{TiO}_{2}$ immobilized in glass spheres $\left(\sim 0.6 \mathrm{mg}\right.$ of $\mathrm{TiO}_{2}$ was supported on the surface of each glass sphere);

(n)

inorganic anions present in WW and also to the NOM that could compete with the spiked contaminants for oxidizing species.

- $125 \mathrm{~W}$ black-light fluorescent lamp (300-420 nm);

- Catalyst: $0.2-0.8 \mathrm{~g} \mathrm{~L}^{-1}$ of $\mathrm{TiO}_{2}$.

- Immersion well, batch type, lab scale photoreactor;

- Irradiation source: $9 \mathrm{~W}$ UV-A lamp (350-400 nm);

$\left.\mathrm{mg} \mathrm{L}^{-1}\right)$; - WW effluent (pH 8.0; COD $24 \mathrm{mg} \mathrm{L}^{-1}$; DOC $8.4 \mathrm{mg} \mathrm{L}^{-1}$; conductivity $820 \mu \mathrm{S} \mathrm{cm} \mathrm{c}^{-1} ; \mathrm{Cl}^{-} 172 \mathrm{mg} \mathrm{L}^{-1} ; \mathrm{NO}_{3}^{-} 37$ $\mathrm{mg} \mathrm{L}^{-1}$ ).
Water matrix affected drastically the photocatalytic degradation of bisphenol A, remaining in water approximately $30 \%$. This results could be explained by the presence of substances, such as, organics, $\mathrm{CO}_{3}{ }^{2-}$ and $\mathrm{Cl}^{-}$in the matrix, acting as radical scavengers.

The half-life of diclofenac was lower than that of carbamazepine. The mineralization of the spiked urban WW was lower than that of the spiked DI due to interference of scavengers (e.g., $\mathrm{CO}_{3}{ }^{2-}$ ) and other oxidizable compounds, typically occurring in WWs.

Water matrix showed a negative ffect on conversion and reaction rate. To achieve a complete removal of EE2 in WW, the treatment was three times longer in comparison with UPW and twice longer the needed for WW diluted with an equal volume of UPW, mainly due to the reactions involving the residual organic fraction present in WW and oxidizing agents. Moreover, $\mathrm{HCO}_{3}{ }^{-}, \mathrm{Cl}^{-}$and $\mathrm{SO}_{4}{ }^{2-}$ present in WW and DW can act as scavengers of $\mathrm{HO}^{\circ}$. Similar removal values to those obtained for diluted WW were found for DW samples. 
distinct water matrices. However, the removal efficiency decreased in the following order: UPW > DW > diluted WW $>$ WW. The organic and inorganic constituents typically found in WW and DW impeded degradation presumably due to the scavenging of oxidizing species. Moreover, the presence of HA affected in a greater extent the removal efficiency in comparison to a mixture of anions in UPW experiments.

Photocatalysis

EE2

$100-500 \mu \mathrm{g} \mathrm{L}$

\section{Ibuprofen}

$6 \mu \mathrm{g} \mathrm{L}$

$6,60,213 \mathrm{mg} \mathrm{L}^{-1}$
- UPW; $\mathrm{Cl}^{-} 220 \mathrm{mg} \mathrm{L}{ }^{-1} ; \mathrm{SO}_{4}{ }^{2-} 60 \mathrm{mg} \mathrm{L}{ }^{-1} ; \mathrm{HCO}_{3}{ }^{-} 188 \mathrm{mg} \mathrm{L}^{-1}$; conductivity $820 \mu \mathrm{S} \mathrm{cm}^{-1}$ ), Greece.
- WW effluent (pH 8; DOC $7.8 \mathrm{mg} \mathrm{L}^{-1}$; COD $24 \mathrm{mg} \mathrm{L}^{-1}$;

- Cylindrical Pyrex cell with a useful volume of $300 \mathrm{ml}$;

Solar irradiation simulator (5\% UV-A radiation and $0.1 \%$ UV-B radiation) equipped with a $150 \mathrm{~W}$ xenon ozone-free lamp and an AirMass 1.5 Global Filter; - Catalyst load: $50-500 \mathrm{mg} \mathrm{L}^{-1} \mathrm{ZnO}$

- Spiked WW and UPW (250 mL):

- WW effluent ( $\mathrm{pH} 7.3$; DOC $215 \mathrm{mg} \mathrm{L}^{-1}$; conductivity $610 \mu \mathrm{S} \mathrm{cm}^{-1} ; \mathrm{Cl}^{-} 58 \mathrm{mg} \mathrm{L}^{-1} ; \mathrm{SO}_{4}{ }^{2-} 34 \mathrm{mg} \mathrm{L}^{-1} ; \mathrm{NO}_{3}^{-} 19$ $\mathrm{mg} \mathrm{L}^{-1} ; \mathrm{NO}_{2}^{-} 30 \mathrm{mg} \mathrm{L}^{-1} ; \mathrm{PO}_{4}^{3-} 7 \mathrm{mg} \mathrm{L}^{-1} ; \mathrm{Na}^{+} 40 \mathrm{mg} \mathrm{L}{ }^{-1}$; $\left.\mathrm{NH}_{4}^{+} 22 \mathrm{mg} \mathrm{L}^{-1} ; \mathrm{K}^{+} 10 \mathrm{mg} \mathrm{L}^{-1} ; \mathrm{Ca}^{2+} 21 \mathrm{mg} \mathrm{L}^{-1}\right)$; Portugal. - Pharmaceutical WW (pH 7.9; DOC $170 \mathrm{mg} \mathrm{L}^{-1}$; conductivity $3770 \mu \mathrm{S} \mathrm{cm}^{-1} ; \mathrm{Cl}^{-} 978 \mathrm{mg} \mathrm{L}^{-1} ; \mathrm{SO}^{{ }^{2-}} 661$ $\mathrm{mg} \mathrm{L}^{-1} ; \mathrm{Na}^{+} 310 \mathrm{mg} \mathrm{L}^{-1} ; \mathrm{Mg}^{2+} 27 \mathrm{mg} \mathrm{L}^{-1}$ ), Sfax, Tunisia.
Photoreactor equipped with four $10 \mathrm{~W}$ UV

high intensity LEDs $\left(\lambda_{\max } 382 \mathrm{~nm}\right)$;

Catalyst load: $0.5,1.0,1.5 \mathrm{~g} \mathrm{~L}^{-1} \mathrm{TiO}_{2}$.

Pharmaceutical WW and WW effluent $(7.5 \mathrm{~mL})$ : Quartz cylindrical reactor equipped with a single LED

Catalyst load: $0.5,1.0,2.0,2.5,3.0,4.0$

Among the five different operating variables, the water matrix was the only with a negative effect on the removal efficiency. Since usually estrogens are found in WW effluents, water matrix can have an important role on their treatment, mainly by the presence of organic and inorganic matter. Furthermore, $\mathrm{HO}^{*}$ may be scavenged by $\mathrm{HCO}_{3}-\mathrm{Cl}^{-}$and $\mathrm{SO}_{4}{ }^{2-}$ present in WW.

Lower ibuprofen removals were found when treating WW effluents and pharmaceutical WW in comparison to UPW. Moreover, comparison to UPW. Moreover,
ibuprofen was more difficult to be removed in the case of WW effluent mainly due to the higher $\mathrm{DOC}, \mathrm{NO}_{2}{ }^{-}$, $\mathrm{L}^{-1} \mathrm{TiO}_{2}$. 


\section{Photocatalysis Tetracycline $55 \mathrm{mg} \mathrm{L}^{-1}$}

Photocatalysis Azo dye congo
carbamazepine $10 \mathrm{mg} \mathrm{L}^{-1}$
- UPW (pH 6.6; DOC $8.4 \mathrm{mg} \mathrm{L}^{-1}$; conductivity $0.067 \mu \mathrm{S}$ $\mathrm{cm}^{-1}$; transmittance (at $254 \mathrm{~nm}$ ) 100\%);

- DW (pH 7.8; conductivity $334 \mu \mathrm{S} \mathrm{cm}^{-1} ; \mathrm{Cl}^{-} 5.8 \mathrm{mg} \mathrm{L}^{-1}$;

$\mathrm{NO}_{3}{ }^{-}<5 \mathrm{mg} \mathrm{L}^{-1} ; \quad \mathrm{NO}_{2}{ }^{-}<0.1 \mathrm{mg} \mathrm{L}^{-1} ; \quad \mathrm{SO}_{4}^{2-} 47 \mathrm{mg} \mathrm{L}^{-1}$;

$\mathrm{HCO}_{3}{ }^{-} 63 \mathrm{mg} \mathrm{L}^{-1} ; \mathrm{Ca}^{2+} 68 \mathrm{mg} \mathrm{L}^{-1} ; \mathrm{Mg}^{2+} 11.5 \mathrm{mg} \mathrm{L}^{-1}$

transmittance (at $254 \mathrm{~nm}$ ) $97.6 \%$ );

- WW effluent (pH 8; conductivity $855 \mu \mathrm{S} \mathrm{cm} \mathrm{cm}^{-1}$; COD

$24 \mathrm{mg} \mathrm{L}^{-1} ; \mathrm{Cl}^{-} 92 \mathrm{mg} \mathrm{L}^{-1} ; \mathrm{NO}_{3}^{-} 23 \mathrm{mg} \mathrm{L}^{-1}$,

$\mathrm{NO}_{2}^{-} 48 \mathrm{mg} \mathrm{L}^{-1} ; \quad \mathrm{SO}_{4}{ }^{2-} 74 \mathrm{mg} \mathrm{L}{ }^{-1} ; \quad \mathrm{HCO}_{3}{ }^{-} \quad 156$

$\mathrm{mg} \mathrm{L}^{-1} ; \mathrm{Ca}^{2+} 88 \mathrm{mg} \mathrm{L}^{-1} ; \mathrm{Mg}^{2+} 54 \mathrm{mg} \mathrm{L}^{-1}$; transmittance (at $254 \mathrm{~nm}$ ) $61.6 \%$ ).
- Photocatalytic reactor $(500 \mathrm{~mL})$

- Irradiation source: $18 \mathrm{~W}$ lamp emitting at

$254 \mathrm{~nm}$;

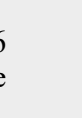

The removal efficiency of
tetracycline was higher in DW in comparison with UPW, which could be explained by the presence of dissolved organic matter acting as photosensitizer with the generation of reactive species. However, the removal decreased when WW was used as matrix. The organic matter could act as a filter for UV radiation and $\mathrm{HO}^{\circ}$ can be scavenged by the high concentration of $\mathrm{HCO}_{3}^{-}$and $\mathrm{Cl}^{-}$ present in the WW effluent.

\section{Photocatalysis}

Acetaminophen,
thiabendazole,
acetamiprid
$100 \mu \mathrm{g} \mathrm{L}^{-1}$

red, - DI; - Saline water (pH 7.5; conductivity $1300818 \mu \mathrm{S} \mathrm{cm}^{-1}$,
$\mathrm{NaCl} 1 \mathrm{~g} \mathrm{~L}^{-1}, \mathrm{KH}_{2} \mathrm{PO}_{4} 6 \mathrm{mg} \mathrm{P} \mathrm{L}^{-1}$ );

- WW effluent (pH 7.5; conductivity $1700818 \mu \mathrm{S} \mathrm{cm}^{-1}$, COD $30 \mathrm{mg} \mathrm{L}^{-1} ; \mathrm{PO}_{4}^{-3} 6 \mathrm{mg} \mathrm{P} \mathrm{L}^{-1} ; \mathrm{NO}_{3}{ }^{-} 30 \mathrm{mg} \mathrm{N} \mathrm{L}^{-1}$ ), collected from a lab-scale MBR system fed on real municipal primary effluent.
Glass cylinder (1 L) photo-reactor, quipped with an axial quartz tube holding the UV lamp;

Catalysts: Hydrogen titanate nanofiber and commercial $\mathrm{TiO}_{2}(\mathrm{P} 25)$;

-8W lamp ( $\lambda$ 360nm).
- CPC solar pilot plant;

- Solar simulator equipped with a Xenon lamp and a $290 \mathrm{~nm}$ cut-off filter;

Catalyst: $\mathrm{TiO}_{2}$-coated glass beads.
The photocatalytic activity of both catalysts was similar in saline water and effluent, but the degradation of the target compounds had an opposite trend regarding the matrix effects. Matrix effect on the dark adsorption of congo red was higher in real effluents than in saline water, while carbamazepine had negligible adsorption, explained by the different polarity, which causes different adsorption and interaction with the catalyst surface. Anions affected slightly the removal rates, whereas calcium had a pronounced negative effect on the photocatalytic performance using nanofiber catalyst. The matrix effect led to a reduction of degradation rate due to the presence of other substances in the matrix (organics, $\mathrm{CO}_{3}{ }^{2-}$, etc.), which can be adsorbed onto the catalyst surface (blocking and/or competing for reaction sites) and/or compete for $\mathrm{HO}^{*}$ in the bulk.
- WW effluent ( $\mathrm{pH} 8.4$; conductivity $2670 \mu \mathrm{S} \mathrm{cm}^{-1}$, DOC $21.10 \mathrm{mg} \mathrm{L}^{-1}$; IC $60.4 \mathrm{mg} \mathrm{L}^{-1} ; \mathrm{Cl}^{-1} 12.9 \mathrm{mg} \mathrm{L}^{-1} ; \mathrm{SO}_{4^{2-}} 1.85$ $\mathrm{mg} \mathrm{L}^{-1} ; \mathrm{Na}^{+} 23.0 \mathrm{mg} \mathrm{L}^{-1} ; \mathrm{NH}_{4}^{+} 0.06 \mathrm{mg} \mathrm{L}^{-1} ; \mathrm{K}^{+} 0.68 \mathrm{mg}$ $\left.\mathrm{L}^{-1} ; \mathrm{Ca}^{2+} 65.7 \mathrm{mg} \mathrm{L}^{-1} ; \mathrm{Mg}^{2+} 4.82 \mathrm{mg} \mathrm{L}^{-1}\right)$, Spain. 
- Solar simulator equipped with a Xenon $50 \mathrm{mg} \mathrm{L}^{-1}$ ;

\section{Photocatalysis Carbamazepine $5 \mathrm{mg} \mathrm{L}^{-1}$}

Photocatalysi

$$
\text { Ofloxacin, atenolol }
$$$$
10 \mathrm{mg} \mathrm{L}^{-1}
$$

- UPW

- GW;

- WW effluent (pH 8.22; TOC $11 \mathrm{mg} \mathrm{L}^{-1}$; COD $6 \mathrm{mg} \mathrm{L}^{-1}$; turbidity 1.9 NTU; conductivity $1424 \mu \mathrm{S} \mathrm{cm}^{-1}$; TSS $4.5 \mathrm{mg}$ $\mathrm{L}^{-1} ; \mathrm{N}_{\text {total }} 3.7 \mathrm{mg} \mathrm{L}^{-1} ; \mathrm{P}_{\text {total }} 2.96 \mathrm{mg} \mathrm{L}^{-1} ; \mathrm{N}^{-N_{H}}{ }_{4}^{+} 0.16 \mathrm{mg}$ $\left.\mathrm{L}^{-1} ; \mathrm{Cl}^{-1} 196 \mathrm{mg} \mathrm{L}-\right)$, Cyprus.

\section{Photocatalysis Diclofenac, fluoxetine $\mathrm{mg} \mathrm{L}^{-1}$ levels}

Photocatalysis

\section{Sulfamethoxazole} $10 \mathrm{mg} \mathrm{L}^{-1}$ m $10.4 \mathrm{NTU}$; alkalinity $471 \mathrm{mg} \mathrm{CaCO}_{3} \mathrm{~L}^{-1}$; TSS 18.8 $\mathrm{mg} \mathrm{L}^{-1}$; VSS $14.6 \mathrm{mg} \mathrm{L}^{-1} ; \mathrm{Cl}^{-} 745 \mathrm{mg} \mathrm{L}^{-1} ; \mathrm{NO}_{3}{ }^{-} 3.0$ $\mathrm{mg} \mathrm{L}{ }^{-1}$; $\mathrm{NO}_{2}{ }^{-}$n.d.; $\mathrm{PO}_{4}{ }^{3-} 15 \mathrm{mg} \mathrm{L}^{-1}$; $\mathrm{SO}_{4}{ }^{2-} 232 \mathrm{mg} \mathrm{L}^{-1}$; $\mathrm{NH}_{4}^{+} 57.1 \mathrm{mg} \mathrm{L}^{-1} ; \mathrm{Na}^{+} 495 \mathrm{mg} \mathrm{L}^{-1} ; \mathrm{K}^{+} 45.9 \mathrm{mg} \mathrm{L}^{-1}$; $\left.\mathrm{Ca}^{2+} 138 \mathrm{mg} \mathrm{L}^{-1} ; \mathrm{Mg}^{2+} 59.6 \mathrm{mg} \mathrm{L}^{-1}\right)$, Spain.
- DI;

- WW effluent (pH 6.15; TOC $5.15 \mathrm{mg} \mathrm{L}^{-1}$; DOC $4.65 \mathrm{mg}$ $\mathrm{L}^{-1}$; SS $\left.11 \mathrm{mg} \mathrm{L}^{-1}\right)$, Portugal. $\mathrm{nm}$ );

Photon flux $2.99 \times 10^{-6}$ Einstein $\mathrm{s}^{-1}$ (290-400 nm);

Duran tubular photoreactor $(24 \mathrm{~cm}$ length, $2.11 \mathrm{~cm}$ diameter, $0.078 \mathrm{~L}$ illuminated volume) placed at the bottom of the solarbox in the axis of a parabolic mirror; Recirculation at a flow rate of $0.65 \mathrm{~L}$ $\min ^{-1}$;

- Catalyst: boron-modified $\mathrm{TiO}_{2}(5 \% \mathrm{w} / \mathrm{w}$ of B)

- V $1.0 \mathrm{~L} ; \mathrm{T} 25^{\circ} \mathrm{C}$.

- WW effluent from a lab-scale MBR used to treat primary WWs from a WWTP (COD 13.5-22 $\mathrm{mg} \mathrm{L}^{-1}$; $\mathrm{PO}_{4}^{3-}$
$23.8 \mathrm{mg} \mathrm{L}^{-1} ; \mathrm{NO}_{3}^{-}$210-238 $\mathrm{mg} \mathrm{L}^{-1}$ ), South Australia

Sequential

photoreactor;

- Low-intensity (11 W) UV-C lamp;

- Catalysts: immobilized $\mathrm{TiO}_{2}$, namely anatase titanate nanofiber and mesoporous $\mathrm{TiO}_{2}$ impregnated kaolinite;

- Presence of effluent organic matter and inorganic ions.

$-9 \mathrm{~W}$ lamp emitting predominantly at 350 $400 \mathrm{~nm}$;

-Catalyst: $0.25 \mathrm{~g} \mathrm{~L}^{-1}$ of $\mathrm{TiO}_{2}$.

- XX-15 BLB UV lamp ( $\lambda 365 \mathrm{~nm})$,

Catalysts: Single-phase Hydroxyapatite (HAp) and HAp-titania (TiHAp) materials (1 wt $\% \mathrm{TiO}_{2}$ );

- DI: spiked with 2-8 $\mathrm{mg} \mathrm{L}^{-1}$; catalyst load between 1 and $4 \mathrm{~g} \mathrm{~L}^{-1}$,

Effluents: spiked with $5 \mathrm{mg} \mathrm{L}^{-1}$ of both contaminants; $4 \mathrm{~g} \mathrm{~L}^{-1}$ of TiHAp.

- 9W lamp emitting predominantly at 350 nm;

- GW;

- WW effluent (pH 8.22; TOC $11 \mathrm{mg} \mathrm{L}^{-1}$; COD 6 mg L $\mathrm{L}^{-1}$; Catalyst: $0.5 \mathrm{~g} \mathrm{~L}^{-1}$ of $\mathrm{TiO}_{2}$ turbidity $1.9 \mathrm{NTU}$; conductivity $1424 \mu \mathrm{S} \mathrm{cm}^{-1}$; TSS $4.5 \mathrm{mg}$

$\mathrm{L}^{-1} ; \mathrm{N}_{\text {total }} 3.7 \mathrm{mg} \mathrm{L}^{-1} ; \mathrm{P}_{\text {total }} 2.96 \mathrm{mg} \mathrm{L}^{-1} ; \mathrm{N}^{-N_{H}}{ }^{+} 0.16 \mathrm{mg}$

$\left.\mathrm{L}^{-1} ; \mathrm{Cl}^{-1} 196 \mathrm{mg} \mathrm{L}^{-}\right)$, Cyprus.
The optimal photocatalyst concentration was higher in WW due to the competition of organic matter for active species generated and for adsorption in the photocatalyst surface. Inorganic ions may also interfere, by deactivation of the catalyst surface.

The sequential batch annular slurry photoreactor system was successfully applied for the elimination of carbamazepine from WW, but high molecular weight effluent organic matter competed for the photocatalytic reaction. The presence of inorganic ions interfered with the surface fouling of immobilized photocatalysts, reducing their photoactivity.

The extent of mineralization followed the decreasing order: UPW $>\mathrm{GW}>$ WW. This could be attributed to the corresponding TOC increment and other species present in the actual matrices, which are able to scavenge radicals or other reactive moieties.

The HAp-titania photocatalyst was effective when using actual treated WW, but the removal efficiency decreased by $20 \%$ for diclofenac and by $4 \%$ for fluoxetine, probably due to the suspended solids present in the WW. The degradation rate using centrifuged WW was comparable to that observed in DI.

The degradation was favoured at acidic $\mathrm{pH}$. Comparing to UPW, the matrix effects on degradation were negligible, even for WW with high TOC and GW with high content of $\mathrm{HCO}_{3}^{-}$, both known scavengers of radicals. At near-neutral $\mathrm{pH}$, the 
Photocatalysis

Sulfonamides (sulfathiazole, - DI;

sulfamethoxazole,

sulfadiazine)

$5 \mathrm{mg} \mathrm{L}^{-1}$

- Influents (with and without preliminary filtration and coagulation);

- WW effluents (pH 7.10-7.66; conductivity 1204-1722 $\mu \mathrm{S}$ $\mathrm{cm}^{-1}$; COD 137-774 $\mathrm{mg} \mathrm{L}^{-1}$; BOD $560-89 \mathrm{mg} \mathrm{L}^{-1}$; turbidity

4-50), Poland.

\section{Photocatalysis Carbamazepine}

$133 \mathrm{ng} \mathrm{L}^{-1}$

\section{- Deionized water;}

- WW effluent from a sequential batch reactor (SBR) activated sludge process with phosphate precipitation by $\mathrm{Fe}^{3+}$ (pH 7.7; TOC $10 \mathrm{mg} \mathrm{L}^{-1}$, electrical conductivity 803 $\mu \mathrm{mho} \mathrm{cm}^{-1}$; IC $26.3 \mathrm{mg} \mathrm{L}^{-1}$; alkalinity $139 \mathrm{mg} \mathrm{CaCO}_{3} \mathrm{~L}^{-1}$ )

Temperature: between 21 and $25^{\circ} \mathrm{C}$; Catalyst: $100 \mathrm{mg} \mathrm{L}^{-1}$ of $\mathrm{TiO}_{2}$;

- $\mathrm{pH} 7.3$;

- Presence and absence of powdered activated carbon.

presence of co-existing substances in environmental samples slightly affected the degradation of the pharmaceutical, suggesting that the ionic strengths of both environmental matrices had a role on promoting the agglomeration of $\mathrm{TiO}_{2}$ particles, decreasing the effective surface area.

The optimum photocatalytic system

4 UV lamps emitting at $\lambda_{\max } 366 \mathrm{~nm}$;

Catalyst: $0.5 \mathrm{~g} \mathrm{~L}^{-1}$ of $\mathrm{TiO}_{2}$ and/or $1 \mathrm{mM}$ was $\mathrm{TiO}_{2} / \mathrm{FeCl}_{3}$ under acid $\mathrm{pH}$. The of $\mathrm{FeCl}_{3}$;

degradation rate was significantly lower in WW than in DI. Similar results were obtained using the model WW. Preliminary microfiltration and coagulation of the influents did not improved the photocatalytic efficiency, in comparison to untreated influents.

The photocatalytic efficiency was matrix and $\mathrm{pH}$ dependent. Carbamazepine present in the WW (pH 7.3) was not completely removed by photocatalysis with a UV dose of about $6 \mathrm{~kJ} \mathrm{~L}^{-1}$. In contrast, spiking carbamazepine at $10 \mathrm{mg} \mathrm{L}^{-1}$ in carbamazepine at $10 \mathrm{mg} \mathrm{L}^{-1}$ in
deionized water and in acidic effluent led to an efficient removal with the same UV dose. Under alkaline conditions, the UV dose needed for the same removal from the spiked effluent was 10 times higher.

Photocatalysis Diclofenac, carbamazepine, - DI; ibuprofen and propranolol

-WW effluent (pH 7.3; DOC $12.2 \mathrm{mg} \mathrm{L}^{-1}$; COD $35.2 \mathrm{mg}$ $5 \mathrm{mg} \mathrm{L}^{-1}$

$\mathrm{L}^{-1}$. BOD $6 \mathrm{mg} \mathrm{L}^{-1}, \mathrm{Cl}^{-} 49.5 \mathrm{mg} \mathrm{L}^{-1}, \mathrm{SO}_{4}^{2-} 24.4 \mathrm{mg} \mathrm{L}^{-1}$. $\mathrm{NO}_{3}^{-} 4.5 \mathrm{mg} \mathrm{L}^{-1}$; TN $7.2 \mathrm{mg} \mathrm{L}^{-1}$; TP $\left.0.55 \mathrm{mg} \mathrm{L}^{-1}\right)$, The Netherlands.

- Simulated solar irradiation (96 h): Xenon Photolysis efficiency was enhanced high-intensity discharge lamps $(55 \mathrm{~W})$ by the DOM present in WW effluent, mitting at $\lambda$ range of $300-800 \mathrm{~nm}$; Stirring at $75 \mathrm{rpm}$; - Catalyst: $25 \mathrm{~g}$ of immobilized $\mathrm{TiO}_{2}$.

organic matter, which might absorb light to excite triplet states of DOM $\left({ }^{3} \mathrm{DOM}^{*}\right)$ and further to reactive radicals. $\mathrm{NO}_{3}{ }^{-}$could also play a role by adsorption of light $<350 \mathrm{~nm}$ and production of $\mathrm{HO}^{\circ}$, accelerating the indirect photolysis. Photocatalysis led to superior removal efficiencies for all pharmaceuticals. However, carbamazepine and ibuprofen were degraded at less extent in WW, probably due a proposed partial or selective reduction of the oxidized intermediates back to parent compounds. 


$\begin{array}{llll}\text { Photocatalysis- } & \text { Diclofenac, naproxen and } & \text { - UPW; } \\ \text { DCMD (direct } & \text { ibuprofen } & \text { - DW; } \\ \text { contact } & 100 \mu \mathrm{g} \mathrm{L}^{-1} & \text { - Primary WW effluents; } \\ \text { membrane } & & \text { - Secondary WW effluents, Poland. } \\ \text { distillation) } & & \end{array}$

distillation)
Photocatalysis Carbamazepine

$50 \mu \mathrm{M}$
- DW;

- WW effluents.
- Photoreactor equipped with an UV-C germicidal lamp $\left(\lambda_{\max } 254 \mathrm{~nm}\right)$ located between a feed tank and a membrane module;

- Catalyst load: $0.5 \mathrm{~g} \mathrm{~L}^{-1}$ of $\mathrm{TiO}_{2}$;

- DCDM: hydrophobic polypropylene membranes, with an area of $0.014 \mathrm{~m}^{2}$ and nominal pore size of $0.2 \mu \mathrm{m}$;

- Feed and distillate solution temperatures: 60 and $20^{\circ} \mathrm{C}$.

Carbamazepine/peroxymonosulphate (PMS) molar ratio: from 1 to 30 ;

- Cobalt salts tested: $\mathrm{CoCl}_{2} .6 \mathrm{H}_{2} \mathrm{O}$ and $\mathrm{Co}\left(\mathrm{NO}_{3}\right)_{2} .6 \mathrm{H}_{2} \mathrm{O}$.

Photocatalysis

Diatrizoate $\left(744 \pm 28 \mu \mathrm{g} \mathrm{L}^{-1}\right), \quad$ - WW effluent (pH 7.7 \pm 0.3 ; conductivity $1.3 \pm 0.2 \mathrm{mS} \mathrm{cm}^{-}$ acetaminophen $\left(736 \pm 36 \mu \mathrm{g} \quad{ }^{\prime}\right.$; DOC $6 \pm 2 \mathrm{mg} \mathrm{L}^{-1}$; COD $18 \pm 6 \mathrm{mg} \mathrm{L}^{-1}$; $\mathrm{BOD}_{5} 3.4 \pm 1.7 \mathrm{mg}$

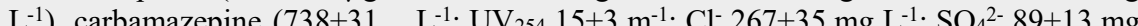
$\left.\mu \mathrm{g} \mathrm{L}^{-1}\right)$, atenolol $(757 \pm 67 \mu \mathrm{g}$ $\mathrm{L}^{-1}$ $\mathrm{L}^{-1} ; \mathrm{UV}_{254} 15 \pm 3 \mathrm{~m}^{-1} ; \mathrm{Cl}^{-} 267 \pm 35 \mathrm{mg} \mathrm{L}^{-1} ; \mathrm{SO}_{4}^{2-} 89 \pm 13 \mathrm{mg}$
$\mathrm{L}^{-1} ; \mathrm{NO}_{3}^{-} 7 \pm 3 \mathrm{mg} \mathrm{L}^{-1} ; \mathrm{NO}_{2}^{-} 0.08 \pm 0.06 \mathrm{mg} \mathrm{L}^{-1} ; \mathrm{HCO}_{3}^{-}$ $259 \pm 64 \mathrm{mg} \mathrm{L}^{-1} ; \mathrm{Na}^{+} 152 \pm 14 \mathrm{mg} \mathrm{L}^{-1} ; \mathrm{Ca}^{2+} 160 \pm 17 \mathrm{mg} \mathrm{L}^{-1}$ $\left.\mathrm{Mg}^{2+} 6.6 \pm 0.8 \mathrm{mg} \mathrm{L}^{-1} ; \mathrm{K}^{+} 22 \pm 3 \mathrm{mg} \mathrm{L}^{-1}\right)$, France.

\section{Photocatalysis Trimethoprim}

$\left(\mathrm{TiO}_{2}\right.$ and $1 \mathrm{mg} \mathrm{L}^{-1}$
- WW effluent (pH 7.30; conductivity $2.15 \mathrm{mS} \mathrm{cm}^{-1}$; - CPC solar pilot plant; turbidity 4.2 NTU; TOC $13.9 \mathrm{mg} \mathrm{L}^{-1}$; IC $59.5 \mathrm{mg} \mathrm{L}^{-1} ; \mathrm{Cl}^{-} \quad$-V $39 \mathrm{~L}$;

$477.4 \mathrm{mg} \mathrm{L}{ }^{-1} ; \mathrm{SO}_{4}^{2-} 157.5 \mathrm{mg} \mathrm{L}{ }^{-1} ; \mathrm{NO}_{3}^{-} 47 \mathrm{mg} \mathrm{L}^{-1} ; \mathrm{Na}^{+} \quad$ - Catalyst: $200 \mathrm{mg} \mathrm{L}{ }^{-1} \mathrm{TiO}_{2}$;

$\begin{array}{ll}269.5 \mathrm{mg} \mathrm{L}^{-1} ; \mathrm{Ca}^{2+} 81 \mathrm{mg} \mathrm{L}^{-1} ; \mathrm{Mg}^{2+} 54.4 \mathrm{mg} \mathrm{L}^{-1} ; \mathrm{NH}_{4}^{+} & \text {- HA: } 10 \mathrm{mg} \mathrm{L}^{-1} \text {; } \\ \left.25.1 \mathrm{mg} \mathrm{L}^{-1}\right) & \text { - Sodium persulph }\end{array}$ $\left.25.1 \mathrm{mg} \mathrm{L}^{-1}\right)$.

- Natural water ( $\mathrm{pH} 7.55$; conductivity $1.1 \mathrm{mS} \mathrm{cm}^{-1}$; TOC $2.6 \mathrm{mg} \mathrm{L}^{-1}$; IC $89.4 \mathrm{mg} \mathrm{L}^{-1} ; \mathrm{Cl}^{-1} 148 \mathrm{mg} \mathrm{L}^{-1} ; \mathrm{SO}_{4}^{2-} 159.4$
Modular tube reactor;

Irradiation source: UV-A lamp $(\lambda 365$ $\mathrm{nm}, 3-40 \mathrm{Wuv} \mathrm{m}^{-2}$ );

Recirculation flow rate: $1.5 \mathrm{~L} \mathrm{~min}^{-1}$; - Catalyst: $2 \mathrm{~g} \mathrm{~L}^{-1} \mathrm{TiO}_{2}$.

- Sodium persulphate: $0.125-0.5 \mathrm{mM}$;
$\mathrm{UVA} / \mathrm{TiO}_{2}$ and $\mathrm{UVA} / \mathrm{ZnO}$ system led to a significant degradation of the analysed pharmaceuticals and in the particular case of carbamazepine, for which the matrix effect was also studied. Similar results were obtained when comparing UPW and WW for each photocatalytic system, but $\mathrm{ZnO}$ nanoparticles showed a better performance.

A PMR using DCMD and UV-C radiation was applied to WWTP effluents. In general the removal efficiency by the hybrid process was in the following decreasing order, except for diclofenac: UPW > tap water $>$ secondary effluent $>$ primary effluent. Diclofenac was faster removed in the primary vs secondary effluents, possibly due to adsorption of the drug on the suspended matter present in the WW.

Sulphate radical yielded a faster degradation of carbamazepine compared to $\mathrm{HO}^{*}$, in both real and DI. The WW matrix had an important effect on the inhibition of degradation by both $\mathrm{PMS} / \mathrm{Co}$ (II) and Fenton systems. The $\mathrm{Cl}^{-}$ions were involved in the inhibition effect, but the organic matter could also affect the oxidation kinetic decrease.

Organic matter, phosphate and bicarbonate ions affected negatively the process efficiency by $\mathrm{HO}^{\circ}$ scavenging. Consequently, the kinetic constant of mineralization decreased. Degradation of target compounds ranged from $20 \%$ to $80 \%$, decreasing for higher volumetric reduction factor.

The removal occurred by the combination of heterogeneous photocatalysis, photolysis and persulphate oxidation. Trimethoprim degradation rate decreased as the complexity of the matrix increases. The addition of sodium persulphate 


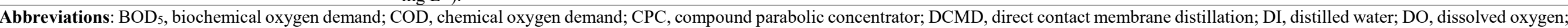

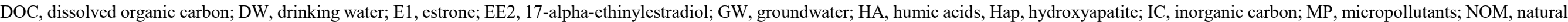

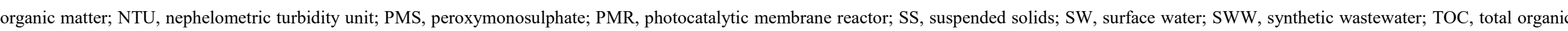
carbon; TS, total solids; TSS, total suspended solids; UPW, ultrapure water; VSS, volatile suspended solids; WW, wastewater; WWTP, wastewater treatment plant. 
Table S5. Matrix effects occurring in studies dealing with ozone-based processes, published since 2005. Unless otherwise stated, the experimental conditions refer to the tested conditions for the evaluation of matrix effects.

\begin{tabular}{|c|c|c|c|c|c|}
\hline AOT & $\begin{array}{l}\text { Target pollutant } \\
\text { Concentration }\end{array}$ & Matrices & Experimental conditions & Main conclusions & Reference \\
\hline $\mathrm{O}_{3} / \mathrm{H}_{2} \mathrm{O}_{2}$ & $\begin{array}{l}\text { Atrazine, } \\
\text { sulfamethoxazole, N- } \\
\text { nitrosodimethylamine } \\
0.5-11 \mu \mathrm{M}\end{array}$ & $\begin{array}{l}\text { - } 3 \text { Lake waters, Switzerland and Norway; } \\
\text { - WW effluent (DOM } 3.9 \mathrm{mg} \mathrm{C} \mathrm{L}^{-1} \text {; alkalinity } \\
6.5 \mathrm{mg} \mathrm{CaCO}_{3} \mathrm{~L}^{-1} \text { ), Switzerland. }\end{array}$ & $\begin{array}{l}\text { - } 500 \mathrm{~mL} \text { batch reactor; } \\
\text { - T } 20{ }^{\circ} \mathrm{C} \text {; } \\
\text { - pH } 8.0 \text {; } \\
\text { - Spiked } \mathrm{O}_{3} \text { stock solution; } \\
\text { - Addition of } \mathrm{H}_{2} \mathrm{O}_{2}\left(2: 1, \mathrm{O}_{3} / \mathrm{H}_{2} \mathrm{O}_{2}\right) \text { prior to } \\
\mathrm{O}_{3} \text { addition. }\end{array}$ & $\begin{array}{l}\text { The } \mathrm{O}_{3} \text { dose needed was higher for WW. The } \\
\text { addition of } \mathrm{H}_{2} \mathrm{O}_{2} \text { enhanced the removal and } \\
\text { reduced bromate formation. Generally, the waters } \\
\text { with lower DOM concentration and/or lower } \mathrm{HO} \\
\text { scavenging rates had a higher transformation. The } \\
\text { reactivity of DOM was different in waters with the } \\
\text { same DOC concentration. The content on } \mathrm{CO}_{3}{ }^{2-} \\
/ \mathrm{HCO}_{3}^{-} \text {led to an inhibitory effect of } \mathrm{O}_{3} \text { decay. }\end{array}$ & [13] \\
\hline $\begin{array}{l}\text { UV } \\
\mathrm{O}_{3} \\
\mathrm{O}_{3} / \mathrm{UV} \\
\text { Photocatalysis } \\
\text { Catalytic } \\
\text { ozonation } \\
\text { Photocatalytic } \\
\text { ozonation }\end{array}$ & $\begin{array}{l}\text { Diclofenac, } \\
\text { sulfamethoxazole, } \\
\text { caffeine } \\
10 \mathrm{mg} \mathrm{L}^{-1}\end{array}$ & $\begin{array}{l}\text { - UPW; } \\
\text { - WW effluent (pH 7-8; TOC } 35 \mathrm{mg} \mathrm{L}^{-1} \text {; IC } 23 \\
\text { mg L-1; COD 58-84 mg L-1; BOD 30-60 mg L- } \\
\text { 1), Spain. }\end{array}$ & 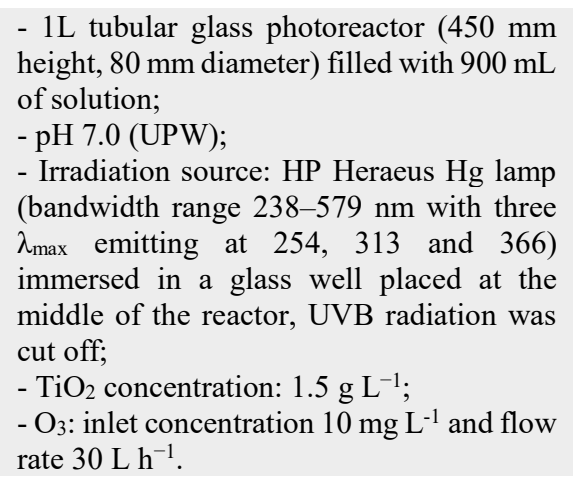 & $\begin{array}{l}\text { Diclofenac elimination rate with UVA radiation } \\
\text { was higher in WW than that in UPW, possibly due } \\
\text { to some substance present in the effluent acting as } \\
\text { photosensitizing agent. The removal rates of all } \\
\text { compounds and TOC by the other AOTs were } \\
\text { slightly slower in WW. For all the } \\
\text { pharmaceuticals, no significant differences were } \\
\text { verified on their removal by single } \mathrm{O}_{3} \text { with/without } \\
\text { the presence of } \mathrm{HCO}_{3}-\mathrm{CO}_{3}^{2-} \text {, suggesting that } \\
\text { direct attack by } \mathrm{O}_{3} \text { is the main mechanism. }\end{array}$ & {$[28]$} \\
\hline $\mathbf{O}_{3}$ & $\begin{array}{l}\text { Metoprolol, naproxen, } \\
\text { amoxicillin, phenacetin } \\
1 \mu \mathrm{M}\end{array}$ & $\begin{array}{l}\text { - GW, Spain; } \\
\text { - SW from a public reservoir, Spain; } \\
\text { - } 3 \text { WW effluents (pH 7.8-8.1; TOC 13.2-23.3 } \\
\text { mg L L }^{-1} \text { COD } 28.2-49.7 \mathrm{mg} \mathrm{L}^{-1} \text {; conductivity } \\
637-905 \mu \mathrm{S} \mathrm{cm}^{-1} \text {; alkalinity } 93-325 \mathrm{mg} \mathrm{CaCO} \\
\mathrm{L}^{-1} \text { ), Spain. }\end{array}$ & $\begin{array}{l}\text { - Each run was initiated by injecting a } \\
\text { variable volume of the } \mathrm{O}_{3} \text { stock solution to } \\
\text { achieve a dose of } \mathrm{O}_{3} \text { varying between } 0.5 \\
\text { and } 5 \mathrm{mg} \mathrm{L}^{-1} \text { for the secondary effluents, } \\
\text { and between } 0.1 \text { and } 2 \mathrm{mg} \mathrm{L}^{-1} \text { for the } \\
\text { natural waters; } \\
\text { - } \mathrm{T} 20^{\circ} \mathrm{C} \text {; } \\
\text { - pH } 7 \text { by using the phosphoric } \\
\text { acid/phosphate buffer; } \\
\text { - Initial concentrations of p-chlorobenzoic } \\
\text { acid of } 1.0 \mu \mathrm{M} \text {. }\end{array}$ & $\begin{array}{l}\text { The removal of pharmaceuticals in the WW was } \\
\text { lower than in the SW, which was in turn lower than } \\
\text { in GW. The amount of dissolved organic matter } \\
\text { present in each water explains this trend (COD and } \\
\text { TOC: GW }<\text { SW }<\text { WW effluents). The organic } \\
\text { matter content consumed part of the oxidant in } \\
\text { competition with the pharmaceuticals. }\end{array}$ & [87] \\
\hline
\end{tabular}




\section{UV \\ Photocatalysis \\ $\left(\mathrm{TiO}_{2}\right.$ and \\ persulphate (PS)}

Photo-Fenton

UV/PS/Fe

\section{Photocatalysis \\ Photo-Fenton}

$\mathrm{O}_{3} / \mathrm{H}_{2} \mathrm{O}_{2}$
- DI;

- Synthetic WW; $44 \mathrm{mg} \mathrm{L}^{-1}$; COD $71 \mathrm{mg} \mathrm{L}^{-1} ; \mathrm{NO}_{3}^{-} 2.1 \mathrm{mg} \mathrm{L}^{-1}$; $\mathrm{mg} \mathrm{L}^{-1}$ ).
- WW effluent (pH 8.6; DOC $18.5 \mathrm{mg} \mathrm{L}^{-1}$; IC $\mathrm{NO}_{2}^{-} 0.02 \mathrm{mg} \mathrm{L}^{-1} ; \mathrm{PO}_{4}^{3-} 4.1 \mathrm{mg} \mathrm{L}{ }^{-1} ; \mathrm{SO}_{4}^{2-} 58$
- Three 30W UV-C LP lamps (254 nm); - Catalysts: $\mathrm{TiO}_{2}$ at $50,100,200 \mathrm{mg} \mathrm{L}^{-1}$ an persulphate at $25,50,100 \mathrm{mg} \mathrm{L}^{-1}$.

$-\mathrm{H}_{2} \mathrm{O}_{2}: 25,50,100 \mathrm{mg} \mathrm{L}^{-1}$;

- pH natural (2.8 for $\left.\mathrm{UV} / \mathrm{H}_{2} \mathrm{O}_{2} / \mathrm{Fe}\right)$;

- Effect of organic matter: addition of HA, lignin-derivative and lauryl sulphate.
- T $25{ }^{\circ} \mathrm{C}$ and $\mathrm{pH} 7.0$, except for photo- DI; - WW effluent (pH 7.45; COD $119 \mathrm{mg} \mathrm{L}^{-1} ; \quad$ Fenton (pH 3.0); The order of the inhibition caused by matrix BOD $250 \mathrm{mg} \mathrm{L}^{-1} ; \mathrm{N}_{\text {total }} 30 \mathrm{mg} \mathrm{L}^{-1} ; \mathrm{P}_{\text {total }} 0.38 \mathrm{mg}$ Photo-Fenton

- Three $4 \mathrm{~W}$ near-UV-A (black light) fluorescent lamps with a radiation peak at $352 \mathrm{~nm}$;

$-\mathrm{Fe}^{2+}: 10 \mathrm{mg} \mathrm{L}^{-1}$

$-\mathrm{H}_{2} \mathrm{O}_{2}: 100 \mathrm{mg} \mathrm{L}-1$

$\mathrm{O}_{3} / \mathrm{H}_{2} \mathrm{O}_{2}$

- $\mathrm{O}_{3}$ : inlet concentration $0.36 \mathrm{mg} \mathrm{L}^{-1}$ and flow rate $3.0 \mathrm{~L} \mathrm{~h}^{-1}$

$-\mathrm{H}_{2} \mathrm{O}_{2}: 20 \mathrm{mg} \mathrm{L}^{-1}$;

Heterogeneous photocatalysis

- $\mathrm{TiO}_{2}: 200 \mathrm{mg} \mathrm{L}^{-1}$

$\mathrm{O}_{3}$

Tetrabromobisphenol $100 \mathrm{mg} \mathrm{L}^{-1}$

- UPW spiked with anions and HA;

- River water (pH 7.49; DOC 9.10 mg L-1);

- Raw WW (pH 7.74; DOC $45.31 \mathrm{mg} \mathrm{L}^{-1}$ );

- WW effluent (pH 7.65; DOC $\left.17.04 \mathrm{mg} \mathrm{L}^{-1}\right)$.

- $100 \mathrm{~mL}$ conical flasks filled with $50 \mathrm{~mL}$ of pollutant solution;

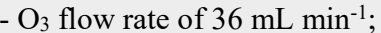

- inlet $\mathrm{O}_{3}$ concentration in the gas phase was measured as $140.6 \mathrm{mg} \mathrm{L}^{-1}$.

- Effect of inorganic ions $\left(\mathrm{Cl}^{-}, \mathrm{NO}_{3}^{-}, \mathrm{HCO}_{3}\right.$

, $\left.\mathrm{SO}_{4}^{2-}\right)$ at 0.5 and $5.0 \mathrm{mmol} \mathrm{L}^{-1}$;

- Effect of HA at 5.0 and $50.0 \mathrm{mg} \mathrm{L}^{-1}$.

$\mathbf{O}_{3}$

Flumequine

$20 \mu \mathrm{g} \mathrm{L}^{-1}-20 \mathrm{mg} \mathrm{L}^{-1}$

- UPW;

- River water;

- WW influent

- WW effluent (characterization not provided)
All processes at neutral $\mathrm{pH}$ were able to effectively remove acetamiprid, being the photo-Fenton the most efficient for all water matrices. UV/PS and UV/PS/Fe systems also showed good efficiencies. The matrix effect retarded the removal rates, due to the high alkalinity and organic matter content of both synthetic and actual effluents. HA interfered with UV photolysis at high concentration due to the absorptivity of UV radiation. In turn, they had no impact on $\mathrm{UV} / \mathrm{H}_{2} \mathrm{O}_{2} / \mathrm{Fe}$ and $\mathrm{UV} / \mathrm{PS} / \mathrm{Fe}$ processes. AOTs using iron probably originated $\mathrm{Fe}(\mathrm{II})$ complexes with lignin, acting as filter due to the high absorptivity. The lauryl sulphate did not promoted the formation such complexes at natural $\mathrm{pH}$, leading to similar removal rates for all processes. components was as follows: $\mathrm{O}_{3} / \mathrm{H}_{2} \mathrm{O}_{2}>\mathrm{UV} / \mathrm{TiO}_{2}$ $>\mathrm{UV} / \mathrm{H}_{2} \mathrm{O}_{2} / \mathrm{Fe}$. For $\mathrm{UV} / \mathrm{H}_{2} \mathrm{O}_{2} / \mathrm{Fe}$, the Fenton existing substances, possibly providing additional iron ions, while the photo-reduction was inhibited by the complex-forming reaction and/or light scattering. For $\mathrm{UV} / \mathrm{TiO}_{2}$, substances present in the matrix could inhibit the removal via scavenger effects, light scattering and adsorption. In the $\mathrm{O}_{3} / \mathrm{H}_{2} \mathrm{O}_{2}$ process, the matrix affected the mass transfer of $\mathrm{O}_{3}$ from the gas to the liquid phase, in addition to the scavenger effects on both $\mathrm{HO}^{\circ}$ and dissolved $\mathrm{O}_{3}$.

Tetrabromobisphenol A was completely removed after 6 min of ozonation at $\mathrm{pH} 8.0$. The anions $\left(\mathrm{Cl}^{-}\right.$ , $\mathrm{NO}_{3}{ }^{-}, \mathrm{HCO}_{3}{ }^{-}$and $\mathrm{SO}_{4}{ }^{2-}$ ) and $\mathrm{HA}$ did not significantly affect its degradation. Additionally, no significant difference in the abatement of the the different water matrices. The little influence of WW components in the oxidation rate is probably due to the excessive $\mathrm{O}_{3}$ and $\mathrm{HO}^{*}$ in solution.

The different ions and types of water (UPW, river water, WW influent and effluent) did not influenced the reaction efficiency significantly. However, the DOM extract composed by river sediment behaved as inhibitor and two DOM extracts, namely rice straw and pig manure, promoted the oxidation of the target pollutants pollutant was found employing ozonation to treat
- $100 \mathrm{~mL}$ semi-batch glass reactor filled with $50 \mathrm{~mL}$ of solution stirred at $450 \mathrm{rpm}$; $\mathrm{T} 25^{\circ} \mathrm{C}$;

- $\mathrm{O}_{3}$ continuously bubbled into the reacto bottom at a constant flow rate $(36 \mathrm{~mL}$ $\left.\mathrm{min}^{-1}\right)$ through a glass tube $(0.5 \mathrm{~m})$ with a sintered end;

- Inlet $\mathrm{O}_{3}$ concentration in the gas phase:

$140.6 \mathrm{mg} \mathrm{L}^{-1}$ 
$\mathrm{O}_{3}$

$\mathrm{O}_{3} / \mathrm{H}_{2} \mathrm{O}_{2}$

Metoprolol, naproxen, - UPW;

amoxicillin, phenacetin - $2 \mathrm{WW}$ effluents.

$1 \mu \mathrm{M}$
$-500 \mathrm{~mL}$ cylindrical glass reactor;

- T $25^{\circ} \mathrm{C}$

Natural $\mathrm{pH}$;

$-\mathrm{O}_{3}: 16 \mathrm{mg} \mathrm{h}^{-1}$.

- Cylindrical borosilicate glass photo-

Photocatalytic

ozonation

Diclofenac

$10^{-4}$ and $10^{-6} \mathrm{M}$

- UPW;

- WW effluent ( $\mathrm{pH} 7-8$; TOC $33 \mathrm{mg} \mathrm{L}^{-1}$; IC 28 reactor ( $0.45 \mathrm{~m}$ height, $0.08 \mathrm{~m}$ diameter);

$\mathrm{mg} \mathrm{L}{ }^{-1}$; COD $60 \mathrm{mg} \mathrm{L}^{-1}$; BOD $33 \mathrm{mg} \mathrm{L}^{-1}$ ), - HP Hg lamp (UV-Vis $\lambda>300 \mathrm{~nm}$ );

Spain.

\section{- T $20^{\circ} \mathrm{C} ;$ - pH 7.0}

- Inlet $\mathrm{O}_{3}$ gas concentration: $10 \mathrm{mg} \mathrm{L}^{-1}$;

- Gas flow rate: $30 \mathrm{~L} \mathrm{~h}^{-1}$;

- Catalyst: $1.5 \mathrm{~g} \mathrm{~L}^{-1}$ of $\mathrm{TiO}_{2}$

O3 42 APIs

$1 \mu \mathrm{g} \mathrm{L}-1$

$\mathbf{O}_{3}$

Ofloxacin

$22 \mathrm{mg} \mathrm{L}^{-1}$

Benzalkonium chloride $10 \mathrm{mg} \mathrm{L}^{-1}$

$\mathbf{O}_{3}$

Propiconazole, atrazine,

2,4

dichlorophenoxyacetic
- 6 WW effluents (pH 6.6-7.2; TOC 5.2-13.7 $\mathrm{mg} \mathrm{L}^{-1}$; COD 29-90 $\mathrm{mg} \mathrm{L}^{-1} ; \mathrm{NH}_{4}^{+} 0.77-5.98 \mathrm{mg}$ $\mathrm{L}^{-1}$; alkalinity $\left.154-256 \mathrm{mg} \mathrm{CaCO}_{3} \mathrm{~L}^{-1}\right)$, Sweden.

- WW effluent (pH 7.4; DOC $8.4 \mathrm{mg} \mathrm{L}^{-1}$; COD $28 \mathrm{mg} \mathrm{L}^{-1}$; turbidity 7.0 NTU; conductivity 750 $\mu \mathrm{S} \mathrm{cm}^{-1}$; TSS $11 \mathrm{mg} \mathrm{L}^{-1} ; \mathrm{Na}^{+} 65 \mathrm{mg} \mathrm{L}^{-1} ; \mathrm{NH}_{4}^{+}$ $4.1 \mathrm{mg} \mathrm{L}^{-1} ; \mathrm{K}^{+} 15 \mathrm{mg} \mathrm{L}^{-1} ; \mathrm{Mg}^{2+} 18 \mathrm{mg} \mathrm{L}{ }^{-1} ; \mathrm{Ca}^{2+}$ $52 \mathrm{mg} \mathrm{L}^{-1} ; \mathrm{NO}_{3}^{-} 59 \mathrm{mg} \mathrm{L}^{-1} ; \mathrm{PO}_{4}^{3-} 3.3 \mathrm{mg} \mathrm{L}^{-1}$; $\left.\mathrm{SO}_{4}^{2-} 81 \mathrm{mg} \mathrm{L}^{-1} ; \mathrm{Cl}^{-} 86 \mathrm{mg} \mathrm{L}^{-1}\right)$, Spain.

- Synthetic matrix prepared in UPW spiked with $\mathrm{NaHCO}_{3}$ to equal the alkalinity and $\mathrm{pH}$ values of the WW effluent.

$150 \mathrm{~mL}$ flask reactor;

- Spiked $\mathrm{O}_{3}$ stock solution (concentration $0.5-12 \mathrm{mg} \mathrm{L}^{-1}$ ).

- Cylindrical reactor $(51 \mathrm{~cm}$ height and 6.0 $\mathrm{cm}$ internal diameter) with a total working volume of $1.44 \mathrm{~L}$, operating in continuous co-current mode;

- Average retention time of $10.3 \mathrm{~min}$;

- Water flow rate: $142 \mathrm{~mL} \mathrm{~min}^{-1}$,

- Gas flow was $390 \mathrm{~mL} \mathrm{~min}^{-1}$ with different inlet $\mathrm{O}_{3}$ concentrations;

- Inlet $\mathrm{O}_{3}$ dosage: $4.2-145 \mathrm{mg} \mathrm{O}_{3} \mathrm{~L}^{-1}$;

- Samples taken once the stationary state was reached.

WW influent before biological treatment $(\mathrm{pH}$ - Cylindrical reactor with a total working 8.3; DOC $61.2 \mathrm{mg} \mathrm{L}^{-1}$; COD $121 \mathrm{mg} \mathrm{L}^{-1}$; volume of $1.44 \mathrm{~L}$, operating in continuous turbidity $145 \mathrm{NTU}$; conductivity $1,234 \mu \mathrm{S} \mathrm{cm}^{-}$co-current mode;

'; TSS $108 \mathrm{mg} \mathrm{L}^{-1} ; \mathrm{Na}^{+} 110 \mathrm{mg} \mathrm{L}^{-1} ; \mathrm{NH}_{4}^{+} 53.8$ - Average retention time of $10.3 \mathrm{~min}$; $\mathrm{mg} \mathrm{L}^{-1}, \mathrm{~K}^{+} 26.2 \mathrm{mg} \mathrm{L}^{-1} ; \mathrm{Mg}^{2+} 19.3 \mathrm{mg} \mathrm{L}^{-1} ; \mathrm{Ca}^{2+}$ $41.4 \mathrm{mg} \mathrm{L}{ }^{-1} ; \mathrm{NO}_{3}^{-} 0.10 \mathrm{mg} \mathrm{L}^{-1} ; \mathrm{PO}_{4}^{3-} 14.9 \mathrm{mg}$ $\mathrm{L}^{-1} ; \mathrm{SO}_{4}^{2-} 56.0 \mathrm{mg} \mathrm{L}^{-1} ; \mathrm{Cl}^{-1} 127 \mathrm{mg} \mathrm{L}^{-1}$ ), Spain; - Synthetic matrix prepared in UPW spiked with $\mathrm{NaHCO}_{3}$ to equal the alkalinity and $\mathrm{pH}$ values of the wastewater effluent.

Water flow rate: $142 \mathrm{~mL} \mathrm{~min}^{-1}$.

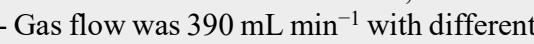
inlet $\mathrm{O}_{3}$ concentrations:

- Inlet $\mathrm{O}_{3}$ dosage: $5-300 \mathrm{mg} \mathrm{O}_{3} \mathrm{~L}^{-1}$;

- Samples taken once the stationary state was reached.

- Ozone dose: 0, 0.2, 0.7, 1.9, 4.9, 9.9 and

$14.8 \mathrm{mg} \mathrm{O}_{3} \mathrm{~L}^{-1}$ in reverse osmosis water;

- SWW;
- WW effluent.
For both processes, the removal rate was lower in the WW effluents than in UPW, due to the presence of DOM in WW, which consumes part of the oxidant, competing with the target substances. The two WW had different DOM contents, giving higher degradation rates for that with less amount of DOM, for both processes. To achieve the same removal, higher oxidant doses would be required. Diclofenac (initial concentration $10^{-4} \mathrm{M}$ ) was completely removed within 6 min and $60-75 \%$ of TOC removals were observed after $60 \mathrm{~min}$, regardless of the matrix. However, for lower initial concentration of diclofenac $\left(10^{-6} \mathrm{M}\right)$ in WW, TOC removal largely depended on the organicinorganic WW content.

A large variability was observed in the required $\mathrm{O}_{3}$ dose to attain elimination of different APIs in the same effluent and for the same API between effluents. The removal was lower when COD and alkalinity were higher, requiring higher $\mathrm{O}_{3}$ doses.

For similar $\mathrm{O}_{3}$ exposures, ofloxacin was removed at a higher extent in synthetic WW, in comparison to WW effluent, showing the competition between the DOM and ofloxacin for $\mathrm{O}_{3}$ and suggesting that $\mathrm{O}_{3}$ and/or $\mathrm{HO}^{*}$ preferably attack certain moieties of DOM present in WW. A higher $\mathrm{O}_{3}$ dose was required to achieve the complete abatement of the pharmaceutical.

Water matrix strongly influenced benzalkonium chloride depletion, in comparison to synthetic WW, mainly due to the high DOC content. An instantaneous ozone demand of $77 \mathrm{mg} \mathrm{L}^{-1}$ was required in non-spiked raw wastewater. The presence of $\mathrm{NiO}$ nanoparticles affected the ozone dose required. The consumed ozone in WW was approximately fivefold the corresponding value in synthetic WW.

As the matrix complexity increased, lower removals of the studied compounds were found. Moreover, in some cases the effect was greater in 


\section{tebuconazole,}

climbazole,

myclobutanil, irgarol,

terbutryn, dicamba,

mecoprop and diuron

5, $20 \mathrm{mg} \mathrm{L}^{-1}$

Catalytic Mesoxalic and oxalic acids

ozonation $50 \mathrm{mg} \mathrm{L}^{-1}$ Sulfamethoxazole,

$\mathrm{O}_{3}$ clofenac $30 \mathrm{mg} \mathrm{L}^{-1}$

\section{3 pharmaceuticals} ng L ${ }^{-1}$ levels

$\mathrm{O}_{3} / \mathrm{H}_{2} \mathrm{O}$

Diclofenac,

sulfamethoxazole, EE2 $10 \mathrm{mg} \mathrm{L}^{-1}$

Catalytic ozonation
- Ozone dose: 0 - $38.2 \mathrm{mg} \mathrm{O} \mathrm{O}_{3} \mathrm{~L}^{-1}$ in $\mathrm{SWW}$ in comparison with WW effluent, mainly synthetic wastewater and wastewater due to the higher COD values, the presence of effluent.

$\mathrm{HCO}_{3}{ }^{-}, \mathrm{PO}_{4}{ }^{3-}$ and $\mathrm{Cl}^{-}$. Furthermore, dicamba and 2,4-dichlorophenoxyacetic acid, followed by atrazine, were the most recalcitrant compounds.

The removal rate by ozonation was almost inhibited by the suspended solids and strongly

(p) 7.7; TOC $8.1 \mathrm{mg} \mathrm{L}^{-1}, \mathrm{COD}-\mathrm{T}^{\circ} 25^{\circ} \mathrm{C}$

$27 \mathrm{mg} \mathrm{L}^{-1}$; turbidity $5.3 \mathrm{NTU}$; conductivity $667 \quad-\mathrm{pH} 8$;

- Catalyst: copper oxide supported on dependent on the presence of inorganic anions,

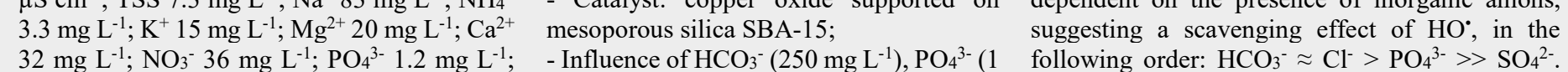

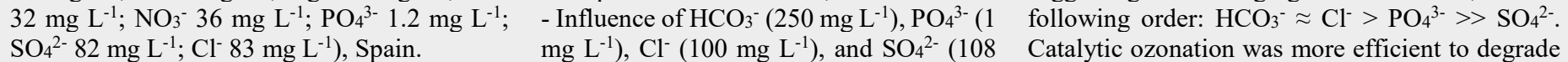

$\left.\mathrm{mg} \mathrm{L}^{-1}\right)$

- Influence of suspended solids. organic acids, being almost unaffected by the presence of the inorganic anions or suspended solids, only $\mathrm{PO}_{4}{ }^{3-}$ having a noticeable effect on oxalic acid depletion.

- Synthetic matrix prepared in DI $(\mathrm{pH} 7 ;-0.5 \mathrm{~L}$ magnetically stirred reactor Significant differences were not found on the $\mathrm{NaHPO}_{4} 1.44 \mathrm{~g} \mathrm{~L}^{-1} ; \mathrm{NaH}_{2} \mathrm{PO}_{4} 0.24 \mathrm{~g} \mathrm{~L}^{-1} ; \mathrm{NaOH}$ $\left.0.5 \mathrm{M} ; \mathrm{COD} 88.5 \pm 4.0 \mathrm{mg} \mathrm{O}_{2} \mathrm{~L}^{-1}\right)$

- WW effluent (pH 7.58; COD $188.2 \pm 13.2 \mathrm{mg}$ $\left.\mathrm{L}^{-1}\right)$.

orating in semi-continuous mode;

- Inlet $\mathrm{O}_{3}$ concentration: $20 \mathrm{~g} \mathrm{Nm}^{-3}$

removal of sulfamethoxazole and diclofenac in both synthetic and WW matrices, which were totally removed in 45 and $60 \mathrm{~min}$, respectively. On the other hand, the removal of COD was much lower, with higher ozone and $\mathrm{H}_{2} \mathrm{O}_{2}$ consumption, when WW was used, which might be explained by the presence of ions, such as $\mathrm{CO}_{3}^{2-}, \mathrm{HCO}_{3}{ }^{-}, \mathrm{SO}_{4}{ }^{2-}$, $\mathrm{PO}_{4}^{3-}$, among others.

The degradation kinetics in urban and domestic WW was significantly different and TOC

- 2 WW effluents: urban WW composed by -5 -L glass jacketed reactor domestic and industrial WW $\left(\mathrm{pH} 7.54-8.01 ;-\mathrm{T} 25^{\circ} \mathrm{C}\right.$;

elimination was markedly higher for urban WW.

5.7-15.7 mg L-1; COD $35-72 \mathrm{mg} \mathrm{L}^{-1}$

- pH 8.0;

- Gas flow rate: $360 \mathrm{~L} \mathrm{~h}^{-1}$,

$\mathrm{cm}^{-1}$; TSS $\approx 0-12.4 \mathrm{mg} \mathrm{L}^{-1}$; alkalinity 345-539 - $\mathrm{O}_{3}$ concentration: $46 \mathrm{~g} \mathrm{~N} \mathrm{~m}^{-3}$.

$\mathrm{mg} \mathrm{CaCO}_{3} \mathrm{~L}^{-1} ; \mathrm{Cl}^{-6} 61-81 \mathrm{mg} \mathrm{L}^{-1} ; \mathrm{SO}_{4}^{2-} 91-133$ $\left.\mathrm{mg} \mathrm{L}^{-}\right)$and domestic WW (pH 7.52-8.38; TOC 8.4-17.5 $\mathrm{mg} \mathrm{L}^{-1}$; COD 44-182 $\mathrm{mg} \mathrm{L}^{-1}$; BOD $_{5}$ 4.7-24 $\mathrm{mg} \mathrm{L}^{-1}$; conductivity $368-631 \mu \mathrm{S} \mathrm{cm} \mathrm{c}^{-1}$; TSS $0.55-23.9 \mathrm{mg} \mathrm{L}^{-1}$; alkalinity $305-580 \mathrm{mg}$ $\mathrm{CaCO}_{3} \mathrm{~L}^{-1} ; \mathrm{Cl}^{-} 52-63 \mathrm{mg} \mathrm{L}^{-1} ; \mathrm{SO}_{4}^{2-} 81-114 \mathrm{mg}$ $\left.\mathrm{L}^{-}\right)$, Madrid, Spain

- WW effluent pre-treated to partially remove its $\mathrm{CO}_{3}{ }^{2-}$ and $\mathrm{HCO}_{3}{ }^{-}$content by stripping $(\mathrm{pH}$ 7.52; TOC $8 \mathrm{mg} \mathrm{L}^{-1}$; COD $64 \mathrm{mg} \mathrm{L}^{-1}$; BOD 515 $\mathrm{mg} \mathrm{L}^{-1}$; turbidity $15.9 \mathrm{NTU}$; conductivity 710 $\mu \mathrm{S} \mathrm{cm}{ }^{-1}$; TSS $28 \mathrm{mg} \mathrm{L}^{-1} ; \mathrm{N}_{\text {total }} 22.1 \mathrm{mg} \mathrm{L}^{-1}$; $\mathrm{NH}_{4}^{+} 18.3 \mathrm{mg} \mathrm{L}^{-1} ; \mathrm{PO}_{4}^{3-} 5.0 \mathrm{mg} \mathrm{L}^{-}$), Spain.
Reactor system: one gas-liquid reactor (300 $\mathrm{mm}$ height, $50 \mathrm{~mm}$ diameter) with porous plate at its bottom to bubble an $\mathrm{O}_{3}$ $\mathrm{O}_{2}$ mixture and a fixed bed reactor where $5 \mathrm{~g}$ of catalyst were loaded;

Catalysts: commercial $\gamma-\mathrm{Al}_{2} \mathrm{O}_{3}$ and synthesized $\mathrm{Co}_{3} \mathrm{O}_{4} / \mathrm{Al}_{2} \mathrm{O}_{3}$;
Regardless of the water matrix and the presence/absence of any catalyst, the elimination of the pharmaceuticals occurred through fast direct reactions with $\mathrm{O}_{3}$ in less than $10 \mathrm{~min}$. Catalytic ozonation, particularly in the presence of the synthesized $\mathrm{Co}_{3} \mathrm{O}_{4} / \mathrm{Al}_{2} \mathrm{O}_{3}$, improved the COD and TOC removals obtained when single ozonation was applied. The ozonation developed through fast initial COD removal followed by a second slower 
Photocatalytic

ozonation

Diclofenac, amoxicillin $0.1 \mathrm{mM}$
- UPW;

- WW effluent (characterization not provided), Portugal.

Formic, acetic, oxalic and maleic acids

Catalytic $7 \mathrm{mg} \mathrm{L}^{-1}$
$\mathrm{O}_{3}$

Photocatalysis Photocatalytic ozonation

$\mathrm{O}_{3}$

$\begin{array}{ll}\mathbf{O}_{3} & \text { Amoxicillin, } \\ \mathbf{U V} & \text { hydrochlorothiazide, } \\ \mathbf{U V} / \mathrm{H}_{2} \mathbf{O}_{2} & \text { metoprolol, naprox }\end{array}$

$\mathrm{O}_{3} / \mathrm{H}_{2} \mathrm{O}_{2}$ as pre- phenacetin

treatment for $1 \mu \mathrm{M}$

nanofiltration
Acetaminophen,

norfloxacin, metoprolol,

cafeine, sulfamethoxazole ketorolac, hydroxylbiphenyl, diclofenac

$50 \mu \mathrm{g} \mathrm{L}-1$

$1 \mu \mathrm{M}$
GW, Spain;

- Surface water from a public reservoir, Spain WW effluent $\left(\mathrm{pH} 7.6\right.$; TOC $15 \mathrm{mg} \mathrm{L}^{-1}$; conductivity $650 \mu \mathrm{S} \mathrm{cm}^{-1}$; alkalinity $250 \mathrm{mg}$ $\left.\mathrm{CaCO}_{3} \mathrm{~L}^{-1}\right)$, Spain.
$\mathrm{O}_{3}: 50 \mathrm{~g} \mathrm{Nm}^{-3}$ and $150 \mathrm{Ncm}^{3} \mathrm{~min}^{-1}$;

- Catalyst: $0.5 \mathrm{~g} \mathrm{~L}^{-1}$ of $\mathrm{TiO}_{2}$.

Cylindrical reactor $(51 \mathrm{~cm}$ height and 6.0 $\mathrm{cm}$ internal diameter) with a total working volume of $1.44 \mathrm{~L}$, operating in continuous co-current mode;

- Average retention time: $10.3 \mathrm{~min}$

- Water flow rate: $142 \mathrm{~mL} \mathrm{~min}^{-1}$;

Gas flow was $390 \mathrm{~mL} \mathrm{~min}{ }^{-1}$ with differen inlet $\mathrm{O}_{3}$ concentrations

$\mathrm{mg} \mathrm{L}^{-1} ; \mathrm{Cl}^{-} 88.2 \mathrm{mg} \mathrm{L}^{-1} ; \mathrm{HCO}$

Synthetic matrix prepared in UPW spiked with $\mathrm{NaHCO}_{3}$ to equal the alkalinity and $\mathrm{pH}$ values of the WW effluent.

WW effluent ( $\mathrm{pH} 8-8.5$; TOC 25-30 $\mathrm{mg} \mathrm{L}^{-1}$; IC 35-40 mg L-1; COD $40 \mathrm{mg} \mathrm{L}^{-1}$ ), Spain.

Copper: $1-250 \mu \mathrm{g} \mathrm{L}-1$ (synthet

$10-500 \mu \mathrm{g} \mathrm{L}-1$ (WW effluent);

- Samples taken once the stationary state was reached.

- $1 \mathrm{~L}$ cylindrical borosilicate glass reactor;

15-W black-light lamps (350-410 nm);

- Catalyst: $0.25 \mathrm{~g} \mathrm{~L}^{-1}$ of $\mathrm{TiO}_{2}$ or $5 \mathrm{~g} \mathrm{~L}^{-1} \mathrm{TiO}_{2}$ supported on activated carbon;

$\mathrm{O}_{3}$ : inlet concentration $15 \mathrm{mg} \mathrm{L}^{-1}$ and flow rate $30 \mathrm{~L} \mathrm{~h}^{-1}$.

$-25 \mathrm{~mL}$ flask reactors;

- T $20^{\circ} \mathrm{C}$; pH natural (7);

- Spiked $\mathrm{O}_{3}$ stock solution or $10^{-3} \mathrm{M}$

hypochlorous acid solution;

- Irradiation source: LP Heraeus Hg lamp

TN $15 / 35$ with a nominal output of $15 \mathrm{~W}$

$(\lambda \max 254 \mathrm{~nm})$

Membrane filtration

- Cross-flow membrane filtration unit Transmembrane pressure: 5 bar (ultrafiltration) and 20 bar (nanofiltration).

- 2.0 L jacketed glass reactor;

O Organophosphate esters - UPW;

- HA solution; - natural $\mathrm{pH}$;

-WW effluent (pH 8.2; TOC $7.8 \mathrm{mg} \mathrm{L}^{-1}$; COD $\mathrm{O}_{3}$

$28.4 \mathrm{mg} \mathrm{L}^{-1}$; turbidity $1.99 \mathrm{NTU}$; alkalinity $325-\mathrm{T} 20^{\circ} \mathrm{C}$

$\mathrm{mg} \mathrm{CaCO} 3 \mathrm{~L}^{-1} ; \mathrm{NH}_{4}^{+} 13.9 \mathrm{mg} \mathrm{L}^{-1} ; \mathrm{Mg}^{2+} 52.1-\mathrm{O}_{3}: 60 \mathrm{~L} \mathrm{~h}^{-1}$ and $10 \mathrm{mg} \mathrm{L}^{-1}$

$\mathrm{mg} \mathrm{L}^{-1} ; \mathrm{Ca}^{2+} 115.4 \mathrm{mg} \mathrm{L}^{-1} ; \mathrm{NO}_{3}^{-} 24.9 \mathrm{mg} \mathrm{L}^{-1} ; \quad \mathrm{UV} / \mathrm{H}_{2} \mathrm{O}_{2}$

$\mathrm{NO}_{2}^{-} 7.35 \mathrm{mg} \mathrm{L}^{-1} ; \mathrm{SO}_{4}^{2-} 203.3 \mathrm{mg} \mathrm{L}^{-1} ; \mathrm{Cl}^{-} 624.2 \quad-\mathrm{T}^{2} 25^{\circ} \mathrm{C}$

$\left.\mathrm{mg} \mathrm{L} \mathrm{L}^{-1}\right)$, Canada. stage, which could be greatly improved by the $\mathrm{Co}_{3} \mathrm{O}_{4} / \mathrm{Al}_{2} \mathrm{O}_{3}$ catalyst.

The removal of the investigated compounds was similar in both matrices. The oxamic acid formed in DI by photocatalytic ozonation was further degraded, whereas it was refractory to the photocatalytic ozonation in the case of spiked WW effluents, where the concentration of this carboxylic acid increased during $45 \mathrm{~min}$ and then remained constant

Catalytic ozonation was strongly influenced by the water matrix, since the complexation with organic matter reduces the availability of metal as catalyst. In WW, a five-fold copper concentration is required to achieve similar removal of oxalic acid to that obtained in the synthetic WW.

The efficiency of the treatments was lower using WW as matrix in comparison to ultra-pure water, due to the effect of other organic/inorganic components occurring in the secondary effluents.

Removal rates by chemical oxidation of water pretreated by membrane filtration showed the following trend among each water matrix: GW > reservoir $>$ WW. The different amount of DOM in each water matrix might consume partially the oxidant and compete with the target substances. In the case of ozonation of WW, higher initial $\mathrm{O}_{3}$ dose was required to achieve similar removal efficiency of those obtained in natural waters.

The aromatic and aliphatic pollutants were rapidly oxidized by ozone and $\mathrm{UV} / \mathrm{H}_{2} \mathrm{O}_{2}$, while the chlorinated and the ramified aliphatic compounds were more recalcitrant. For ozonation, the following decreasing order of removal was reported: HA solution $>$ UPW $>$ WW effluents The acidic $\mathrm{pH}$ of UPW led to selective ozonation of organic compounds with electron-rich 
- 3 LP UV lamps ( $8 \mathrm{~W}, 26 \%$ UVC functional groups. The reactions between $\mathrm{O}_{3}$ and efficiency) $\left(\lambda_{\max } 254 \mathrm{~nm}\right)$;

the electron-rich moieties of HA explain the faster degradation rates of the reactive organophosphate esters due to the production of $\mathrm{HO}^{\circ}$. Direct and indirect oxidation occurred in the municipal secondary effluent ( $\mathrm{pH} 8-8.2)$. The EfOM could react with molecular $\mathrm{O}_{3}$. Some ions (e.g., $\mathrm{Cl}^{-}, \mathrm{SO}_{4}{ }^{2-}$ , $\mathrm{NO}_{3}{ }^{2-}, \mathrm{HCO}_{3}{ }^{-}$) and $\mathrm{EfOM}$ were ascribed as radical scavengers. The reactivity of the target pollutants exhibited a similar trend in $\mathrm{UV} / \mathrm{H}_{2} \mathrm{O}_{2}$ to that in ozonation. The elimination efficiencies in the effluent were generally similar to those in HA solution.

$\begin{array}{ll}\mathbf{O}_{3} & \mathrm{E} 1 \\ \mathbf{U V} & 3 \mu \mathrm{g} \mathrm{L}^{-1}-5 \mathrm{mg} \mathrm{L}^{-1} \\ \mathbf{U V} / \mathbf{H}_{2} \mathbf{O}_{2} & \\ \mathbf{U V} / \mathbf{O}_{3}, & \\ \mathbf{O}_{3} / \mathbf{H}_{2} \mathbf{O}_{2} & \\ \mathbf{O}_{3} / \mathbf{U V} / \mathbf{H}_{2} \mathbf{O}_{2} & \\ \text { Catalytic } & \text { Benzotriazole } \\ \text { ozonation } & 10 \mathrm{mg} \mathrm{L}^{-1}\end{array}$

- UPW;

- Annular reactor $(750 \mathrm{~mL})$;

The best performing treatment for E1 removal was

$36 \mathrm{mg} \mathrm{L}^{-1}$; turbidity $10 \mathrm{NTU}$; TSS $23 \mathrm{mg} \mathrm{L}^{-1} ; \quad-\mathrm{O}_{3}: 0.33-1.31 \mathrm{mg} \mathrm{L}^{-1}$;

ozonation. The removal rate decreased slightly with the background TOC in water, however, in the WW effluent with low COD values, E1 removal TDS $373 \mathrm{mg} \mathrm{L}^{-1} ; \mathrm{Na}^{+} 83.3 \mathrm{mg} \mathrm{L}^{-1} ; \mathrm{NH}_{4}{ }^{+} 2.3 \mathrm{mg} \quad-\mathrm{H}_{2} \mathrm{O}_{2}: 20,40$ and $60 \mathrm{mg} \mathrm{L}^{-1}$

$\mathrm{L}^{-1} ; \mathrm{K}^{+} 10.4 \mathrm{mg} \mathrm{L}^{-1} ; \mathrm{Mg}^{2+} 18.5 \mathrm{mg} \mathrm{L}{ }^{-1} ; \mathrm{Ca}^{2+}$

was only reduced by $5 \%$.

.

The catalyst addition enhanced greatly the removal

WW effluent $(\mathrm{pH}$ 6.5; conductivity $750 \mu \mathrm{S}$ - Semi-continuous reactor;

$\mathrm{cm}^{-1}$; COD $20 \mathrm{mg} \mathrm{L}^{-1}$, TP $15.4 \mathrm{mg} \mathrm{L}^{-1}$; TN 15.4 - V $1.2 \mathrm{~L}$;

$\mathrm{mg} \mathrm{L}^{-1}$; TDS $540 \mathrm{mg} \mathrm{L}^{-1} ; \mathrm{Cl}^{-} 75 \mathrm{mg} \mathrm{L}^{-1} ; \mathrm{NO}_{3}^{-} \quad$ - Catalyst: $0.5 \mathrm{~g} \mathrm{~L}^{-1}$ magnetic alumina

$21.6 \mathrm{mg} \mathrm{L}^{-1} ; \mathrm{NO}_{2}^{-} 2.3 \mathrm{mg} \mathrm{L}^{-1} ; \mathrm{PO}_{4}^{3-} 9.1 \mathrm{mg} \mathrm{L}^{-1} ; \quad$ nanocomposite;

rate of target compound. Experiments using

secondary municipal wastewater effluent indicated

$\left.\mathrm{NH}_{4}^{+} 10.3 \mathrm{mg} \mathrm{L}^{-1}\right)$, Iran.

- Oxygen gas flow rate: $0.3 \mathrm{~L} \mathrm{~min}^{-1}$.

that no significant decrease in the performance of

the catalyst occurred.

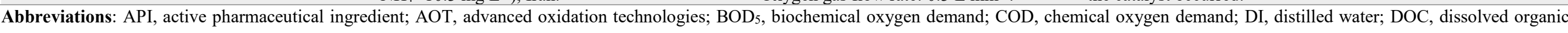

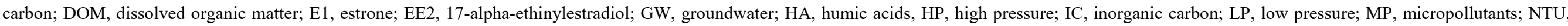

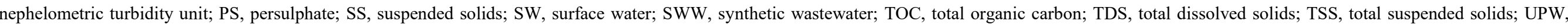

ultrapure water; WW, wastewater. 